\title{
Application of the Sustainable Development of Energy, Water and Environment Systems Index to World Cities with a Normative Scenario for Rio de Janeiro
}

\author{
Şiir Kılkış \\ The Scientific and Technological Research Council of Turkey (TÜBİTAK), Atatürk Bulvarı No: 221, \\ Kavaklidere 06100, Ankara, Turkey \\ e-mail: siir.kilkis@tubitak.gov.tr
}

Cite as: Kilkiş, S., Application of the Sustainable Development of Energy, Water and Environment Systems Index to World Cities with a Normative Scenario for Rio de Janeiro, J. sustain. dev. energy water environ. syst., 6(3), pp 559-608, 2018, DOI: https://doi.org/10.13044/j.sdewes.d6.0213

\begin{abstract}
Urban sustainability is one of the most prominent challenges in the global agenda waiting to be addressed since the Earth Summit in Rio de Janeiro. This research work applies a composite indicator that has been developed as the Sustainable Development of Energy, Water and Environment Systems Index to benchmark the performance of a new sample of 26 world cities. The sample advances the geographical diversity of previous samples and represents cities in the Global Covenant of Mayors for Climate and Energy as well as the C40 initiative. The benchmarking results are analysed based on quartiles of city performance and Monte Carlo simulations. The results indicate the top three cities in the sample to be Copenhagen, which obtains a score of 36.038, followed by Helsinki and Gothenburg. The top cities represent multiple best practices including those in district energy networks, water quality, and environmental management. A normative scenario up to the year 2050 is then applied to one of the cities in the sample, namely Rio de Janeiro. The normative scenario involves targets that take place in local plans, particularly Vision Rio 500. The benchmarking results for the new sample of 26 world cities and the normative scenario not only identifies the benchmark leaders but also underlines opportunities to pursue pathways in which higher levels of performance can be reached by cities that may face multiple challenges. The results of the research work holds significance for advancing the application of an original composite indicator to benchmark cities towards supporting the aim of decoupling economic growth from environmental pressures in more sustainable urban systems towards carbon neutrality.
\end{abstract}

\section{KEYWORDS}

Energy, Water, Environment systems, Benchmarking, Composite indicator, Normative scenario.

\section{INTRODUCTION}

The vitality of addressing an "urban challenge" was underpinned at the international level by such policy landmarks as "Our Common Future" [1]. The immensity of the challenge and rapid patterns of urbanization has since continued to elevate the urgency of the matter. Initially, the need for ensuring the sustainability of urban areas was decisively held at the forefront of sustainability efforts in the Rio Earth Summit, putting forth the guidance of the Rio Declaration on Environment and Development or Agenda 21 [2]. 
Among others, focus was directed to greening of urban settlements, meeting the water needs of the urban populous, protecting water quality in urban environments, managing urban waste and wastewater, reducing urban air pollution, providing for urban mass transit, and enhancing urban data systems [2]. Emphasis was further placed on the need to ensure an overall framework of "sound urban management" to limit the pressures of urban areas on natural systems, including through harnessing and avoiding the extent of urban sprawl [2]. In addition, the United Nations Convention on Climate Change was launched through one of three conventions adopted during the Rio Earth Summit [3].

Since the Rio Earth Summit, additional challenges have risen in prominence and new opportunities have been better defined, particularly the urban energy challenge [4]. The crucial role of cities in leading solutions to mitigate $\mathrm{CO}_{2}$ emissions has become a major strategy [5]. In the United Nations Conference on Sustainable Development that took place 20 years after the Earth Summit, namely Rio+20, urban necessities were further articulated in the outcome document of the "Future We Want" [6]. These included the provision of clean and efficient energy with a significant boost from renewable energy and their integration into urban planning [6]. In this respect, in the road from the Rio Earth Summit to the present time, policy foci for sustainable urban systems are even more pronounced. Sustainable cities and communities is one of the Sustainable Development Goals for 2030, alongside such related goals as "affordable and clean energy, clean water and sanitation, climate action, and responsible consumption and production" [7].

The need to make cities more liveable and have a reduced impact on the environment requires an integration of sectors and solutions across multiple domains. For this reason, a research agenda that is able to effectively support cities in addressing their challenges in undertaking their pursuit towards greater sustainability should be similarly multiplex [8]. The following literature review exemplifies the existing state-of-the-art in the field that promises to have an impact on supporting the sustainability of urban systems through particular case studies at the local level. As evident from the literature review, there is a need for providing additional support towards advancing both a "science of cities" and a "science for cities" [9]. The former is given to focus on understanding and comparing the impacts and responses of cities while the latter aims to provide analytical guidance for cities [9]. Beyond case studies for any particular city, the analysis of multiple cities is also important for which benchmarking for comparing cities becomes a valid approach.

\section{Literature review on sustainable urban systems}

With the majority of the human population concentrated in urban areas [10], cities have a vital stake in determining the sustainability of our Planet. The provided literature review is organized into topics with a focus on leading state-of-the-art research work on urban energy, water, and environment systems. The topics include energy supply, energy usage, transport, circular economy, water and waste issues, air quality, and environment as well as planning and governance at the urban level. The coverage emphasizes those for cities that are signatories or members of major city networks whenever possible, namely Covenant of Mayors (CoM) [11] and the Cities Climate Leadership Group (C40) [12].

Since June 2016, the CoM initiative is enlarged as the Global Covenant of Mayors for Climate and Energy [13]. In addition, new targets for signatory cities are adopted towards achieving at least a $40 \%$ reduction of $\mathrm{CO}_{2}$ emissions from baseline years by the year 2030 [14]. The renewed targets underline the importance of persistent efforts towards reaching net-zero emissions by mid-century to have a chance of limiting global warming to at most $1.5^{\circ} \mathrm{C}$ by 2100 [15]. There are over 7,650 signatories with close to 6,000 actions plans [16]. Analyses based on monitoring reports indicate that emissions from building and transport sectors will reduce by $49 \%$ and $23 \%$ over baseline years by 2020 , respectively [17]. Local energy generation would be able to account for about $20 \%$ of the emission reductions [17].

The C40 initiative started as a climate mitigation network of some of the largest 40 cities that has since increased to about 100 cities, including observers [12]. Similarly, the C40 
initiative has put forth trajectories for its cities towards reaching net-zero emissions by the year 2050 considering the total carbon budget and different city typologies [5]. While all cities are to reach net-zero emissions by the year 2050, the year in which a peaking of emissions is reached can vary by about a 10-year timeframe [5]. All cities, however, are called to contribute to "bending the curve" of global $\mathrm{CO}_{2}$ emissions by the year 2020 [5]. In both contexts, research work in support of more sustainable urban systems is a top priority.

Urban energy supply. In aspects of cleaner energy supply to urban areas, Schroeder and Chapman [18] evaluated low-carbon measures in Chinese cities, including Photovoltaic (PV) panels and ground source or wastewater heat pumps in Beijing and Tianjin. Ramos et al. [19] compared the area that would be needed for Photovoltaic-Thermal (PV-T) units to cover similar shares of building energy needs for thermal energy and electricity in Bucharest, Madrid, Rome, and Seville. Nastasi and Basso [20] proposed power-to-gas applications in the energy systems of Copenhagen, Berlin and Rome to enable a better utilization of renewable energy sources. Unternährer et al. [21] modelled the option of benefiting from the use of geothermal energy in the district heating network of Lausanne based on the spatial analysis of clusters. An et al. [22] proposed a geothermal energy power plant for Tianjin so that it will be possible to benefit from the exergy (useful work potential) that is available in the local hydrothermal resources. Dominković et al. [23] proposed an extensive district cooling network for Singapore to meet the cooling loads.

Urban energy usage. Facchini et al. [24] put forth evidence for lower energy usage with a higher density of urbanized areas in 27 megacities based on energy metabolism. In addition, the residential sector was found to have a determining role in the future energy usage of rapidly developing megacities. Ramachandra et al. [25] analysed energy use by income level in Bangalore to support the low carbon efforts of the city. The results were used to suggest incentives for decentralized solar applications in the city. Sun et al. [26] compared households in Beijing based on energy saving behaviour. Efficient equipment and energy saving practices were more prevalent in households in which residents were considered to be environmentally conscience. Frayssinet et al. [27] simulated the energy demand of Berlin at the micro level of buildings to consider the impact of microclimates in the urban landscape. Qi et al. [28] analysed 16 districts of Beijing based on emergy intensities and indicated the importance of boosting renewable energy and efficiency.

Urban transport. Among numerous studies on urban transport, Fan et al. [29] analysed scenarios for the passenger transport sector in Beijing. The baseline scenario indicated almost a doubling of energy use and greenhouse gas emissions so that the need to expand public transport and complement the network with clean energy vehicles was underlined. Dias et al. [30] forecasted scenarios for electric vehicles in São Paulo and found that emissions from transport may reduce by $1.3 \%$ for each $10 \%$ increment of electric cars that are substituted in the fleet if there is $100 \%$ electricity supply from renewable sources.

Urban wastewater and circular economy. In another aspect, Spriet and Hendrick [31] estimated the potential of using residual heat from wastewater in the capital area of Brussels and found this share to be a maximum of $35 \%$ of residences. Hoek et al. [32] analysed options to recover biogas and nutrients from the wastewater of Amsterdam in the context of efforts for more circular resource usage. Walker et al. [33] applied metrics to identify options for nutrient recovery from wastewater in Greater London to improve urban metabolism, including phosphorous and nitrogen recovery. Gondhalekar et al. [34] proposed a "nexus city" for Munich based on the cultivation of crops in urban areas, the use of biogas from wastewater, and the harvesting of rainwater, among other measures. 
Urban water systems. McDonald et al. [35] analysed the water stress of large cities and their reliance on surface water or groundwater, including the megacities of Tokyo, Beijing, Rio de Janeiro, Istanbul, London, Tianjin, and Bangalore. Water was transported a total distance of about $27,000 \mathrm{~km}$ for the megacities. This result was used to emphasize the need for reducing water leakages, increasing the utilization of recycled water, and any desalination in coastal cities. Lam et al. [36] compared cities based on energy use for water supply and compared the scope of any available reporting for raw water pumping, treatment to obtain tapwater and its distribution, including Copenhagen and Bangalore. Rygaard et al. [37] analysed options for supplying secondary water for non-potable uses in a new district in a former harbour area of Copenhagen, namely the area of Nordhavn.

Urban waste management. Aspects of urban waste management are studied intensively, including in Brazilian cities. Loureiro et al. [38] projected a 7\% increase of emissions from solid waste in a baseline scenario to the year 2030 for the state and city of Rio de Janeiro. Emissions that could be avoided based on solid waste management practices were then compared. Dubeux and La Rovere [39] obtained the $\mathrm{CO}_{2}$ emissions mitigation potential of Rio de Janeiro to be about $4 \mathrm{Mt} \mathrm{CO}_{2}$ based on measures across energy, forest and land use change as well as waste management. Pacheco et al. [40] analysed the status of recycling plastic materials in Rio de Janeiro and identified opportunities to increase value generation from collected plastic. Condeixa et al. [41] assessed the construction and demolition waste from buildings in Rio de Janeiro to determine recycling potential.

Urban air quality and environment. Air quality remains to be an issue for such cities as São Paulo despite improvements. Andrade et al. [42] found that secondary pollutants continue to affect the liveability of São Paulo. Borge et al. [43] analysed a major public square in Madrid based on the variation of $\mathrm{NO}_{2}$ and Particular Matter (PM) levels to determine the exposure of pedestrians to air pollution. In contrast, García et al. [44] used remote sensing data to analyse the change in the share of sealed surfaces in Madrid over a quarter of a century to find a doubling of such a share as a major urbanization challenge. Soares-Gomes et al. [45] analysed the level of environmental stress on Guanabara Bay in Rio de Janeiro that holds particular value for the municipalities in its catchment basin and local public health. Remediation measures to restore the ecosystem were put forth.

Urban planning and governance. As cross-cutting topics, Silva et al. [46] analysed the city of Porto from the perspective of urban form. The results were used to provide guidance to plan building density and mix-used areas for reducing urban energy demand. Chatzipoulka et al. [47] analysed 24 urban forms in London to determine the correlation between the availability of solar energy in the urban context and the geometry of the built environment. Nello et al. [48] used satellite images to determine the brightness levels of cities at night-time, including Amsterdam, London, Lyon, and Madrid, to support urban planning. Kabisch [49] analysed the approach for planning green areas in Berlin and found that better results could be attained by communicating the benefits of green areas.

In related aspects of governance for local initiatives and strategic undertakings, Hu et al. [50] put forth the process of establishing an eco-city with Sino-Singapore cooperation in the suburban outskirts of Tianjin. In contrast, challenges remain for transforming the main urban development of the city. Leeuwen et al. [51] assessed the local challenges of realizing the energy transition in Amsterdam, including the expansion of the district heating network. Dams $\varnothing$ et al. [52] evaluated the path of Copenhagen in pursuing a climate neutrality target based on the cooperation of local authorities and the local utility.

\section{Aims of the present research work}

Given the above literature review on urban systems, there remains a need to support a thorough benchmarking process at the local level towards comparing the sustainable 
development of energy, water and environment systems in cities. In addition to studies that focus on individual cities or a group of cities, benchmarking studies that involve multiple cities across multiple aspects can provide scientific contributions in quantifying the level of proximity or distance in the overall performance of a city relative to others.

The present paper builds upon previous stages of the research work [53-56] in a way that is particularly important for supporting a "science for cities" through benchmarking based on a composite indicator. In addition to a new city sample, the results are used in a scenario analysis that is undertaken for a particular city for the first time. The manuscript is organized such that the method of the research work is first put forth with an emphasis on the selection of the present city sample. The subsequent two sections then underline key aspects of the process of data collection and the results for the present city sample. A scenario that is developed for the home venue of the Rio Earth Summit, namely Rio de Janeiro, is also put forth and discussed in the results. An outlook for the use of the results in support of more sustainable urban systems is presented in the concluding remarks.

\section{METHOD}

The method that is implemented in this research work to advance the benchmarking of cities based on multiple domains of sustainable development with a focus on energy, water and environment systems is based on a composite indicator as developed in previous phases of this research work [53-56]. The index is based on 7 dimensions and 35 main indicators as elaborated in the descriptions provided on the webpage of the International Centre for Sustainable Development of Energy, Water and Environment Systems (SDEWES Centre) [57]. The composite indicator has the namesake of the Centre as the SDEWES Index [58].

In previous phases of the research work, the SDEWES Index was applied to capital and/or most populated cities with available data in the South East Europe (SEE) region $[53,56]$, port cities in the Mediterranean Basin [54], and various cities around the world [55] as summarized based on sample size and geographical focus in Table 1. The first four previous samples involved 76 different cities of which 74 were signatories of the CoM initiative. The present research work consists of three main steps, specifically data collection for the new city sample, analysis of the results based on quartiles of performance as well as Monte Carlo simulations, and the application of a normative scenario to one of the cities in the sample, namely Rio de Janeiro. The subsections below elaborate on the method for these three steps.

Table 1. Overview of the application of the SDEWES Index in previous samples

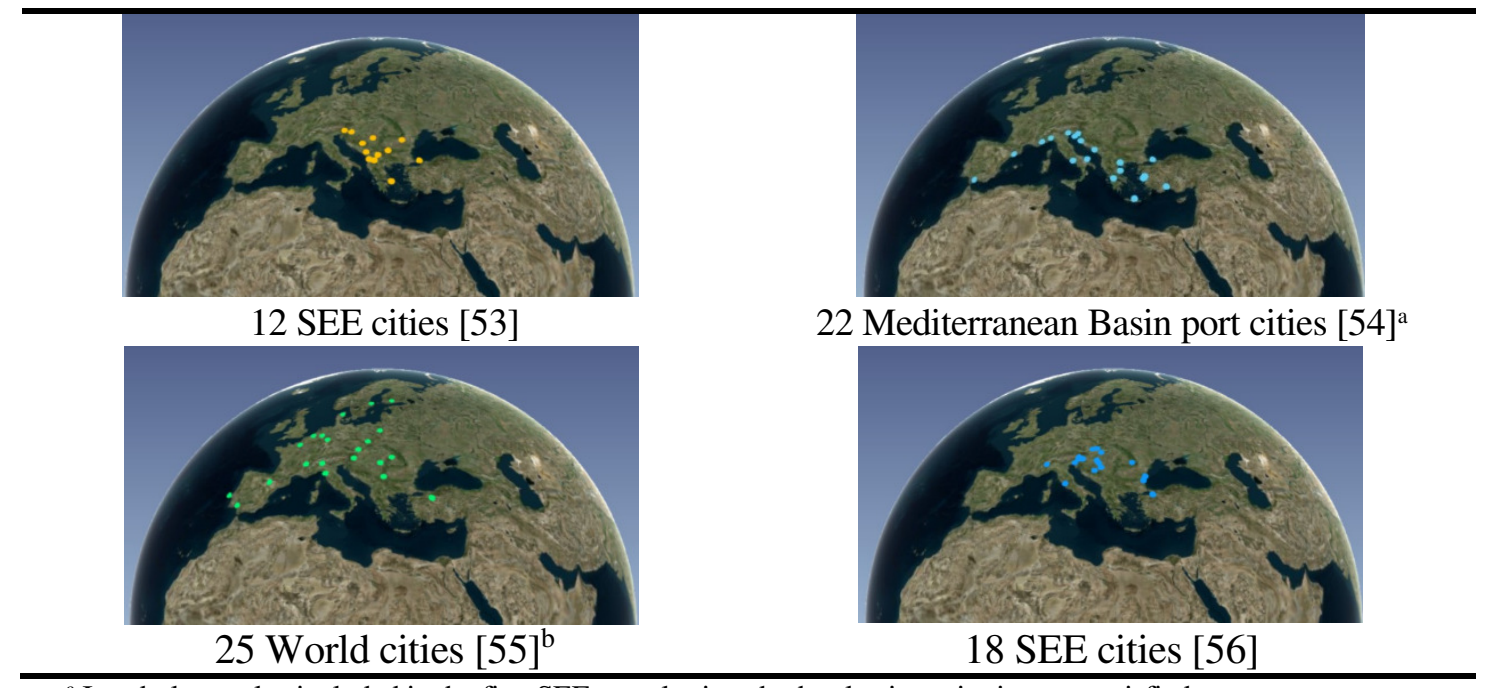

\footnotetext{
${ }^{\mathrm{a}}$ Istanbul was also included in the first SEE sample since both selection criteria were satisfied
}

${ }^{\mathrm{b}}$ The cities of Incheon and Nagoya are not represented in the perspective of the maps in Table 1 


\section{City sample of the present research work}

The sample of the present research work is a new world sample that also represents a greater share of cities from outside the European signatories of the CoM initiative, including cities in the $\mathrm{C} 40$ initiative. Table 2 summarizes the 26 cities in the new sample along with the main reference(s) [59-116] for the original CoM Sustainable Energy and/or Climate Action Plan, namely SEAP or SECAP, updated monitoring report, and present status in the context of the $\mathrm{C} 40$ initiative. Existing research work that analysed aspects of energy, water, and environment related issues for the cities in the sample is further marked based on references [18-52] as a means of linking the cities in the sample with the literature review. Such a new sample brings the total number of cities in the first five samples to 102 cities.

The selection of the cities in the present sample involved a multi-criteria approach to improve the geographical diversity of the sample. First, the availability of energy and $\mathrm{CO}_{2}$ emissions related data is a prerequisite in all samples. In addition, the total number of cities that were included from a given country in previous samples was compared to the total number of CoM signatories from all countries to identify areas of priority in the sample. At the same time, the SDEWES Index is systematically shared through the scientific platform of the SDEWES Conference series [58]. A selection of cities that can represent the cities of participating authors can increase the potential impact of the research results given that researchers can be seen as "change agents" $[117,118]$ in their cities. For this reason, the number of SDEWES authors from all countries that participated in the $11^{\text {th }}$ Conference on SDEWES [119] was evaluated as an additional criterion. The venue of this conference as Lisbon, Portugal was analysed in a previous sample [55] and was excluded for inclusion.

Table 2. Overview of cities in the new sample of the present research work

\begin{tabular}{|c|c|c|c|c|c|c|c|c|}
\hline \multirow{2}{*}{ City $\left(C_{j}\right)$} & \multirow{2}{*}{ Country } & \multicolumn{4}{|c|}{ Main reference(s) for city data } & \multicolumn{3}{|c|}{ Exemplary research work } \\
\hline & & $\mathrm{CoM}$ & Monitoring $^{\mathrm{a}}$ & $\mathrm{C} 40$ & $\operatorname{Ref}(\mathrm{s})$. & Energy & Water & Environ. \\
\hline $\operatorname{Amsterdam}\left(C_{1}\right)$ & Netherlands & $\checkmark$ & & $\checkmark$ & [59-63] & $\checkmark$ & $\checkmark$ & $\checkmark$ \\
\hline Antwerp $\left(C_{2}\right)$ & Belgium & $\checkmark$ & & & [64-65] & & & \\
\hline Bangalore $\left(C_{3}\right)$ & India & & & $\checkmark$ & [66-68] & $\checkmark$ & $\checkmark$ & \\
\hline Batna $\left(C_{4}\right)$ & Algeria & $\checkmark$ & & & [69] & & & \\
\hline Beijing $\left(C_{5}\right)$ & China & & & $\checkmark$ & [70-71] & $\checkmark$ & $\checkmark$ & \\
\hline $\operatorname{Berlin}\left(C_{6}\right)$ & Germany & $\checkmark$ & & $\checkmark$ & [72-73] & $\checkmark$ & & $\checkmark$ \\
\hline Bilbao $\left(C_{7}\right)$ & Spain & $\checkmark$ & & & [74] & & & \\
\hline Braga $\left(C_{8}\right)$ & Portugal & $\checkmark$ & & & {$[75]$} & & & \\
\hline Bregenz $\left(C_{9}\right)$ & Austria & $\checkmark$ & $\checkmark$ & & [76-77] & & & \\
\hline Bydgoszcz $\left(C_{10}\right)$ & Poland & $\checkmark$ & & & [78] & & & \\
\hline Copenhagen $\left(C_{11}\right)$ & Denmark & $\checkmark$ & & $\checkmark$ & [79-81] & $\checkmark$ & $\checkmark$ & $\checkmark$ \\
\hline Florence $\left(C_{12}\right)$ & Italy & $\checkmark$ & $\checkmark$ & & [82-83] & & & \\
\hline Gothenburg $\left(C_{13}\right)$ & Sweden & $\checkmark$ & $\checkmark$ & & [84-86] & & & \\
\hline Grand Lyon $\left(C_{14}\right)$ & France & $\checkmark$ & & & [87-89] & $\checkmark$ & & $\checkmark$ \\
\hline Helsinki $\left(C_{15}\right)$ & Finland & $\checkmark$ & $\checkmark$ & & [90-92] & & & \\
\hline Karlovac $\left(C_{16}\right)$ & Croatia & $\checkmark$ & $\checkmark$ & & [93-95] & & & \\
\hline London $\left(C_{17}\right)$ & United King. & $\checkmark$ & & $\checkmark$ & [96-99] & $\checkmark$ & $\checkmark$ & $\checkmark$ \\
\hline $\operatorname{Lviv}\left(C_{18}\right)$ & Ukraine & $\checkmark$ & $\checkmark$ & & {$[100-101]$} & & & \\
\hline Madrid $\left(C_{19}\right)$ & Spain & $\checkmark$ & & $\checkmark$ & [102-104] & $\checkmark$ & & $\checkmark$ \\
\hline Porto $\left(C_{20}\right)$ & Portugal & $\checkmark$ & & & [105-106] & $\checkmark$ & & \\
\hline Rio de Janeiro $\left(C_{21}\right)$ & Brazil & & & $\checkmark$ & [107-108] & $\checkmark$ & $\checkmark$ & $\checkmark$ \\
\hline Salé $\left(C_{22}\right)$ & Morocco & $\checkmark$ & & & [109] & & & \\
\hline São Paulo $\left(C_{23}\right)$ & Brazil & & & $\checkmark$ & [110] & $\checkmark$ & & $\checkmark$ \\
\hline Tianjin $\left(C_{24}\right)$ & China & & & & [111-112] & $\checkmark$ & $\checkmark$ & $\checkmark$ \\
\hline Vila Nova de Gaia $\left(C_{25}\right)$ & Portugal & $\checkmark$ & $\checkmark$ & & [113-114] & & & \\
\hline Vilnius $\left(C_{26}\right)$ & Lithuania & $\checkmark$ & $\checkmark$ & & [115-116] & & & \\
\hline
\end{tabular}

\section{Data collection, normalization and aggregation}

According to the method of this research work, the SDEWES Index is applied for the first time to the cities that take place in Table 2 to determine the benchmark leader of the 
present sample. In this process, data is collected for each indicator for each city in the sample and normalized based on the Min-Max method [120]. The direction of the indicators as summarized in [56] determines the descending or ascending order of the normalized values. Since the Min-Max method is relative to a given sample, the performances of these cities are benchmarked to all other cities to which the SDEWES Index has been applied to date for consistency based on the use of common minimum and maximum values [121]. Any outliers are identified based on higher order moments, including skewness greater than 2 and kurtosis greater than 3.5 [122]. Any outliers are addressed according to winsorization that can be used to substitute such values with the subsequent value in the data set given that these cases remain below threshold shares [122]. The steps of data collection and processing enable the next steps for normalization and aggregation to obtain index values for each city.

Eq. (1) provides the means of aggregating the normalized values of the five indicators in each dimension per any city in the sample $C_{j}$ from $j=1$ to $j=26$. Here, $I_{x . y}\left(C_{j}\right)$ is the normalized value of a given indicator in a given dimension numbered $x$ with indicator number $y$ for a given city $C_{j}$. The normalization is conducted with the range 0 to 10 so that the maximum possible score in a given dimension and the overall index score is 50. Here, $\alpha_{x}$ is weights with a summation of unity across all dimensions in consistency with previous practices [53-56]. The weights are further subjugated to 10,000 Monte Carlo simulations to consider any possible changes based on the mean simulated values using random weights scaled to unity. The results are compared according to quartiles of city performance. Figure 1 summarizes the dimensions of the SDEWES Index based on seven dimensions $D_{1}$ to $D_{7}$.

$$
\operatorname{SDEWES}\left(C_{j}\right)=\left[\sum_{x=1}^{7} \sum_{y=1}^{5} \alpha_{x} I_{x, y}\left(C_{j}\right)\right] \text { where } \sum_{x=1}^{7} \alpha_{x}=1
$$

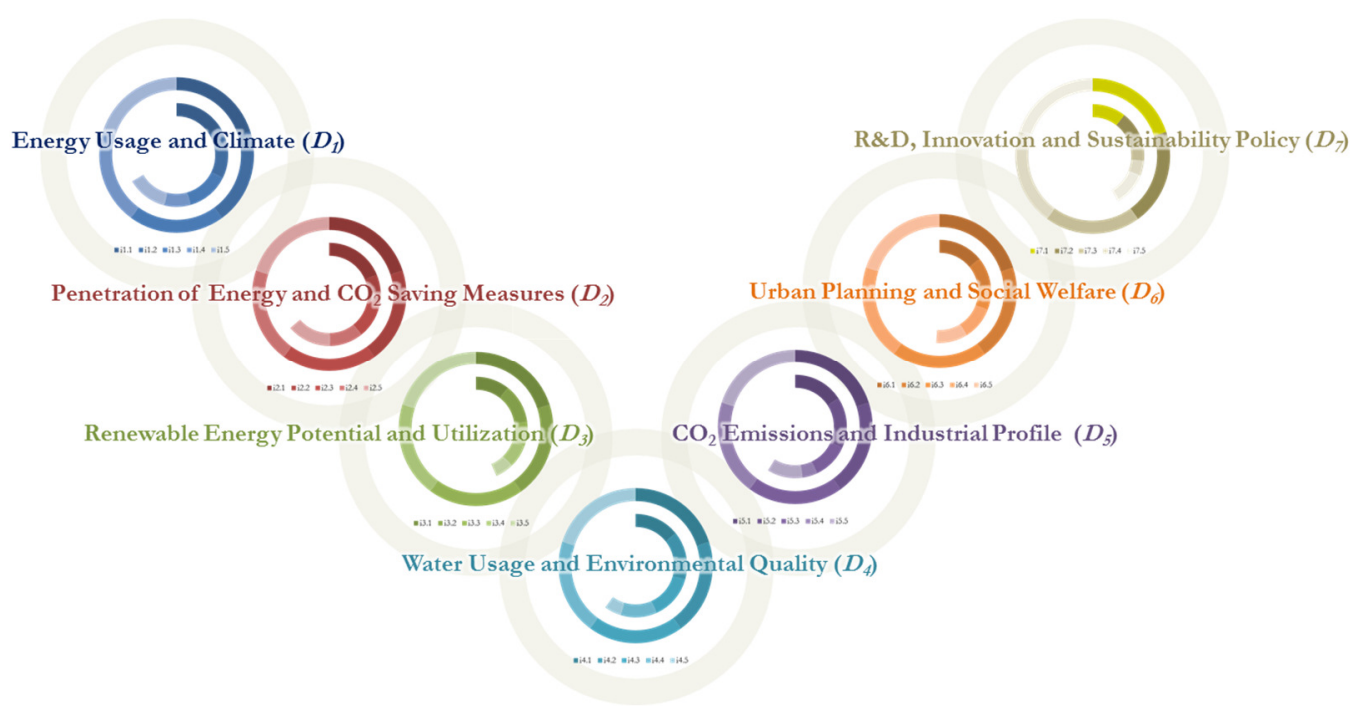

Figure 1. Summary of the dimensions of the SDEWES Index $D_{1}$ to $D_{7}$ [57]

\section{Application of a normative scenario for Rio de Janeiro}

One of the cities that satisfied the criteria for inclusion in the present sample was later announced as the venue of the $1^{\text {st }}$ Latin American SDEWES Conference [123], namely Rio de Janeiro. In this respect, Rio de Janeiro is further subjugated to scenarios that consider the targets in its strategic outlook for the $500^{\text {th }}$ anniversary of the city based on the plan Visão Rio 500 (Vision Rio 500) [124]. In this vision, the city aims to become a "global benchmark" for sustainable development [124]. Moreover, Rio de Janeiro holds 
importance as the first city in a developing country to adopt a carbon neutrality target [125] and has joined other cities during the $23^{\text {rd }}$ Session of the Conference of Parties (COP23) to the UNFCCC to undertake a carbon neutrality target by 2050 [126]. Hence, the application of a scenario to the existing performance of Rio de Janeiro becomes a related objective of the research work. Local aims are also compared with opportunities within the scope of the SDEWES Index.

The scenario is developed to be a "normative scenario" that is defined as a scenario in which a specific future that may be achievable through certain measures or targets is prescribed [127]. In turn, normative scenarios can be used to encourage the realization of those measures. The scenario is developed for a timeframe from the present $\left(t_{0}\right)$ up to the year 2050. Target years in Visão Rio 500 are used to determine annual rates of progress in certain indicators or the years when the best performance of the sample may be reached. When such targets are not explicit, those that are adopted in a scenario for an "Average City" in a subsequent integrated sample of 120 cities are applied [121]. Here, the aim was to reduce the gap between a city performing at an average level and the best performing city.

Eqs. (2-3) govern the annual increases in performance that are taken in the scenario for Rio de Janeiro, which is city $C_{21}$ based on the alphabetical order of cities as presented in Table 2. Here, $i_{x . y}\left(C_{21}\right)_{t 0}$ is the data value of a given indicator based on existing levels of performance. In contrast, $i_{x . y}\left(C_{21}\right)^{\prime} t(z)$ represents the data values in the normative scenario in a future time $t_{(z)}$. Both values are prior to the normalized values in eq. (1). The aspect of implementing eqs. 2 or 3 integrates a new time dimension into the index to enable dynamic evaluations for a scenario. Rio de Janeiro $\left(C_{21}\right)$ thus becomes the first city within the phases of the SDEWES Index to which a scenario is applied based on local targets:

$$
\begin{aligned}
& i_{x . y}\left(C_{21}\right)_{t(z)}^{\prime}=i_{x . y}\left(C_{21}\right)_{t(0)}+z\left[\left(i_{x . y}\left(C_{T}\right)_{t s}-i_{x \cdot y}\left(C_{21}\right)_{t 0}\right) /\left(t_{s}-t_{0}\right)\right] \\
& i_{x \cdot y}\left(C_{21}\right)_{t(z)}^{\prime}=i_{x . y}\left(C_{21}\right)_{t(0)}-z\left[\left(i_{x \cdot y}\left(C_{21}\right)_{t 0}-i_{x \cdot y}\left(C_{T}\right)_{t s}\right) /\left(t_{s}-t_{0}\right)\right]
\end{aligned}
$$

In eq. (2), average annual increases that would be needed to reach the targeted (or best) value by the target year are added to existing levels of performance for indicators in which higher values are more desirable. Eq. (3) represents other instances for indicators in which lower values are desirable so that annual reductions need to take place towards bringing existing levels of performance to the targeted (or best) value. In both eqs. (2) and (3), $i_{x . y}\left(C_{T}\right)_{t s}$ represents the target value in the future that should be reached by the target year $\left(t_{s}\right)$. The number of calendar years that has elapsed between $t_{0}$ and any future time $t_{(z)}$ is accounted by a multiplier $z$. The context of eqs. (2) and (3) thus represents an application of a normative scenario based on the attainment of specific target values by target years. Based on quantitative projections for such a scenario, the SDEWES Index in eq. (1) for Rio de Janeiro is re-calculated using the normalized values of all data inputs, $I_{x . y}\left(C_{21}\right)^{\prime}{ }_{t(z)}$.

\section{SDEWES INDEX APPLICATION}

In the process of applying the method, Tables 3-9 summarize the data collection for the 35 main indicators across dimensions $D_{1}$ to $D_{7}$ of the SDEWES Index for the 26 cities in the sample. The data sources are indicated below each indicator while the entries and sources for the sub-indicators are provided in Tables A1-A10 in the Supplementary Material. The sections below provide a discussion of the collected data prior to the step of normalization. 


\section{Energy usage and climate $\left(D_{1}\right)$}

Based on data for the 26 cities in Table 3 for $D_{1}$, the energy usage of residential, tertiary and municipal buildings in an average city is $21.6 \mathrm{TWh}$. Such a value exceeds those of the transport sector for private and public vehicles as well as the municipal vehicle fleet at 11.2 TWh. On an annual basis, the average city requires $16.89 \mathrm{MWh}$ of energy per capita to provide energy services in buildings, transport, any industry (non-ETS), and public lighting. Recent monitoring reports of the cities in the sample further support a trend of progress towards reductions in urban energy usage within CoM signatories, particularly the building sector [128]. Since the cities in the sample are located in various geographical settings with differing climates, the impact of the climatic context on urban energy demand is represented by the total degree days weighted by an average Coefficient of Performance (COP) for the heating and cooling seasons. For example, Bangalore has an absence of Heating Degree Days (HDD) while Helsinki has limited Cooling Degree Days (CDD). In an average city, the total degree days weighted by average seasonal COP values are 1,173 . Overall, the efficiency with which primary energy spending reaches the end-use sectors is found to be $73.5 \%$.

Table 3. Data inputs to the energy usage and climate dimension $\left(D_{1}\right)$

\begin{tabular}{|c|c|c|c|c|c|}
\hline City $\left(C_{j}\right)$ & $\begin{array}{c}\text { Energy usage } \\
\text { of buildings } \\
\text { [MWh] }\end{array}$ & $\begin{array}{c}\text { Energy usage } \\
\text { of transport } \\
\text { [MWh] }\end{array}$ & $\begin{array}{c}\text { Energy usage } \\
\text { per capita } \\
\text { [MWh/capita] }\end{array}$ & $\begin{array}{c}\text { Total } \\
\text { degree days } \\
{\left[\text { days }{ }^{\circ} \mathrm{C}\right]^{b}}\end{array}$ & $\begin{array}{l}\text { Final to primary } \\
\text { energy ratio }[\%]\end{array}$ \\
\hline Data sources & SEAP $^{\mathrm{a}}$ & SEAPa & SEAP $^{a}$ & [129] & [130] \\
\hline Amsterdam & $12,249,366$ & $2,798,155$ & 25.28 & 968 & 81.1 \\
\hline Antwerp & $8,580,982$ & $3,829,258$ & 24.90 & 1,000 & 77.1 \\
\hline Bangalore & $49,054,162$ & $12,669,417$ & 7.31 & 1,543 & 69.1 \\
\hline Batna & $2,795,000$ & $1,359,000$ & 10.75 & 1,219 & 66.3 \\
\hline Beijing & $119,353,529$ & $67,588,889$ & 29.23 & 1,400 & 68.1 \\
\hline Berlin & $33,497,500$ & $16,739,444$ & 18.95 & 1,144 & 72.0 \\
\hline Bilbao & $1,810,678$ & $1,939,000$ & 10.80 & 1,136 & 70.9 \\
\hline Braga & 931,771 & 930,415 & 10.37 & 955 & 76.2 \\
\hline Bregenz & 300,422 & 197,149 & 22.66 & 1,303 & 85.6 \\
\hline Bydgoszcz & $2,766,390$ & $2,773,149$ & 17.43 & 1,193 & 68.7 \\
\hline Copenhagen & $6,608,611$ & $1,322,348$ & 13.67 & 1,102 & 79.6 \\
\hline Florence & $3,384,000$ & $2,448,000$ & 16.92 & 1,058 & 77.7 \\
\hline Gothenburg & $6,920,000$ & $2,597,189$ & 32.94 & 1,089 & 67.2 \\
\hline Grand Lyon & $15,810,000$ & $7,392,000$ & 24.41 & 1,093 & 62.6 \\
\hline Helsinki & $10,584,869$ & $2,506,876$ & 20.94 & 1,416 & 74.5 \\
\hline Karlovac & 436,863 & 126,081 & 10.21 & 1,160 & 80.3 \\
\hline London & $101,619,000$ & $28,882,000$ & 15.30 & 988 & 69.4 \\
\hline Lviv & $7,536,000$ & $2,272,000$ & 12.93 & 1,272 & 59.5 \\
\hline Madrid & $20,785,950$ & $11,297,731$ & 11.90 & 1,136 & 70.9 \\
\hline Porto & $1,678,000$ & $1,643,000$ & 13.90 & 955 & 76.2 \\
\hline Rio de Janeiro & $16,698,173$ & $20,233,844$ & 7.46 & 1,311 & 77.6 \\
\hline Salé & 913,608 & $1,234,290$ & 2.38 & 1,138 & 75.4 \\
\hline São Paulo & $23,915,927$ & $50,576,944$ & 8.33 & 1,254 & 77.6 \\
\hline Tianjin & $107,176,765$ & $43,506,675$ & 39.73 & 1,398 & 68.1 \\
\hline Vila Nova de Gaia & $2,155,047$ & $2,155,047$ & 14.26 & 955 & 76.2 \\
\hline Vilnius & $4,755,994$ & $3,119,505$ & 16.13 & 1,313 & 82.2 \\
\hline Sample average & $21,627,639$ & $11,236,054$ & 16.89 & 1,173 & 73.5 \\
\hline
\end{tabular}

\section{Penetration of energy and $\mathrm{CO}_{2}$ saving measures $\left(\mathrm{D}_{2}\right)$}

The presence of a strategic framework for climate mitigation and the characteristics of the urban energy supply structure within which energy and $\mathrm{CO}_{2}$ saving measures take place are evaluated in the scope of $D_{2}$ as summarized in Table 4. In the present sample, 21 
cities implement SEAP, SECAP or equivalent plans while 5 cities monitor related data without a similar action plan with detailed measures. In addition to the urban energy supply structure, the status of improving the energy performance of buildings, increasing density of public transport, and upgrading the public lighting infrastructure is subjugated to sub-indicators.

Table 4. Data inputs to the penetration of energy and $\mathrm{CO}_{2}$ measures dimension $\left(D_{2}\right)$

\begin{tabular}{|c|c|c|c|c|c|}
\hline City $\left(C_{j}\right)$ & $\begin{array}{l}\text { Action plan for } \\
\text { energy and } \mathrm{CO}_{2} \\
\text { emissions }\end{array}$ & $\begin{array}{c}\text { Combined } \\
\text { heat and power } \\
\text { based } \mathrm{DH} / \mathrm{C}\end{array}$ & $\begin{array}{l}\text { Energy savings } \\
\text { in end-usage } \\
\text { (buildings) }\end{array}$ & $\begin{array}{l}\text { Density of public } \\
\text { transport network }\end{array}$ & $\begin{array}{c}\text { Efficient } \\
\text { public lighting } \\
\text { armatures }\end{array}$ \\
\hline Data sources & {$[59-116]^{\mathrm{a}}$} & Table $\mathrm{A} 1^{\mathrm{b}}$ & Table A2 ${ }^{c}$ & Table A3 ${ }^{\mathrm{d}}$ & {$[59-116]^{\mathrm{e}}$} \\
\hline Amsterdam & 2.0 & 1.0 & 2.0 & 5.0 & 2.0 \\
\hline Antwerp & 2.0 & 1.0 & 2.0 & 3.0 & 1.0 \\
\hline Bangalore & 0.5 & 1.0 & 1.0 & 3.0 & 1.0 \\
\hline Batna & 2.0 & 0.0 & 1.0 & 1.0 & 1.0 \\
\hline Beijing & 0.5 & 2.0 & 2.0 & 5.0 & 1.0 \\
\hline Berlin & 2.0 & 2.0 & 2.0 & 5.0 & 2.0 \\
\hline Bilbao & 2.0 & 1.0 & 1.0 & 3.0 & 1.0 \\
\hline Braga & 2.0 & 1.0 & 1.0 & 1.0 & 1.0 \\
\hline Bregenz & 2.0 & 1.0 & 2.0 & 1.5 & 1.0 \\
\hline Bydgoszcz & 2.0 & 1.0 & 1.0 & 2.0 & 1.0 \\
\hline Copenhagen & 2.0 & 3.0 & 2.0 & 5.0 & 2.0 \\
\hline Florence & 2.0 & 1.0 & 1.0 & 3.0 & 1.0 \\
\hline Gothenburg & 2.0 & 2.0 & 2.0 & 3.0 & 2.0 \\
\hline Grand Lyon & 2.0 & 2.0 & 2.0 & 4.0 & 2.0 \\
\hline Helsinki & 2.0 & 3.0 & 2.0 & 5.0 & 1.0 \\
\hline Karlovac & 2.0 & 1.0 & 1.0 & 1.5 & 1.0 \\
\hline London & 2.0 & 2.0 & 2.0 & 5.0 & 2.0 \\
\hline Lviv & 2.0 & 2.0 & 1.0 & 3.0 & 1.0 \\
\hline Madrid & 2.0 & 2.0 & 1.0 & 4.0 & 2.0 \\
\hline Porto & 2.0 & 0.0 & 1.0 & 2.0 & 1.0 \\
\hline Rio de Janeiro & 0.5 & 0.0 & 1.0 & 4.0 & 1.0 \\
\hline Salé & 2.0 & 0.0 & 1.0 & 2.0 & 1.0 \\
\hline São Paulo & 0.5 & 0.0 & 1.0 & 4.0 & 1.0 \\
\hline Tianjin & 0.5 & 0.0 & 2.0 & 3.0 & 1.0 \\
\hline Vila Nova de Gaia & 2.0 & 0.0 & 1.0 & 2.0 & 1.0 \\
\hline Vilnius & 2.0 & 2.0 & 1.0 & 3.0 & 1.0 \\
\hline Sample average & 1.7 & 1.2 & 1.4 & 3.2 & 1.3 \\
\hline
\end{tabular}

One of the major shortcomings of urban energy supply structures is the allocation of energy resources that have a high useful work potential, i.e. high exergy, to demands that require low exergy content [131-132]. The most prevalent example is the use of natural gas to meet the low exergy demands of space heating [132]. Cities with Heat Only Boilers (HOB), heat only district energy networks, or any similar reliance are differentiated from those cities in which these may not be the dominant features of the heating and/or cooling sector.

More efficient options include those for District Heating or Cooling (DH/C) networks based on Combined Heat and Power (CHP), the integration of residual sources of heat, including the residual heat of urban wastewater, and developments towards Fourth Generation District Heating (4GDH) networks that operate with lower supply temperatures [133]. These energy supply options are scored categorically considering penetration and the use of renewable energy. The average city receives a score of 1.2 out of a possible score of 3.0 that represents a city with a DH/C network based on CHP with more than a $75 \%$ share in the urban thermal energy load and developments toward 4GDH networks. In Copenhagen, district heating based on biomass and waste covers $98 \%$ of the city with progress towards 4GDH [79]. Suburbs at Albertslund and Høje Taastrup are renovated for low-temperature district heating in which the heat loss has been reduced from $40 \%$ to $13 \%$ with $555 \mathrm{MWh}$ annual energy savings [134]. Helsinki utilizes Thermal 
Energy Storage (TES) in support of more efficient and flexible energy supply structures. TES units 35 meters below the ground support the network with 14,500 district heating and 250 district cooling connections [135].

Table A1 details the characteristics of the urban energy supply structure for all cities. For example, the district energy system of Gothenburg uses large-scale heat pumps and includes the integration of waste heat from industrial processes [85]. By the year 2030, the remaining share of fossil fuels in the DH system will be phased-out with the use of renewable and residual energy [84]. By the same year, Berlin is pursuing an energy concept to phase-out coal usage based on solutions for gas or biogas based CHP, renewable energy, and power-to-gas solutions [72]. Within this concept, Berlin is investigating the use of low-exergy transmission pipes with different temperature levels [136]. Antwerp plans to use residual heat from the port area to heat buildings in a Nieuw Zuid district [137]. Vilnius is increasing the share of cogenerated energy to maximize primary energy savings [138].

Other cities plan to integrate large-scale solar heat and geothermal energy (Amsterdam [59]) or lakewater (Bregenz [76]) in the future as part of urban energy efforts. In Braga, renewable generation based on PV, biomass CHP, and solar thermal is planned to reduce fossil fuel use by about 12,321 MWh per year [75]. In contrast, the opportunity to progress towards more advanced urban energy systems is not being utilized in other cities. Presently in Bangalore, district cooling that is more efficient than individual air conditioning units is not planned while related initiatives are starting in pilot Indian cities [139]. Individual air conditioning units are prevalent in Rio de Janeiro that has similar options for district cooling while only building-scale trigeneration units were analysed for the Olympic Games [140].

In addition to the energy supply structure, renovation measures to improve the energy performance of residential, commercial, and municipal buildings are expected in local plans. The average energy use of residential $\left(173 \mathrm{kWh}\right.$ per $\left.\mathrm{m}^{2}\right)$ and non-residential buildings $\left(251 \mathrm{kWh}\right.$ per $\mathrm{m}^{2}$ ) per year in the European building stock under normal climate conditions [141] represents significant room for improvement. In contrast, cities that have implementations of nearly Net-Zero Energy Buildings (nZEB), energy-plus buildings, carbon neutral buildings and/or districts can obtain advantages towards transforming the local building stock. Buildings that meet the nZEB target have high energy performance for reduced energy loads that are covered by a significant share of renewable energy sources [142]. In most cases, primary energy use intensity should not be higher than $50 \mathrm{kWh}$ per $\mathrm{m}^{2}$ per year [142]. The details of nZEB related developments are given in Table A2. Cities that have successful undertakings of such targets include those at the building and some at the district levels. In London, a zero-carbon target for residential development has come into effect [98] while the zero energy development site BedZED [143] relies on renewable energy sources. In Amsterdam, local regulations encouraged only climate-neutral buildings to be built from 2015 onwards [59]. The building of the China Academy of Building Research in Beijing operates as a nearly nZEB [144] while the Nieuw Zuid area of Antwerp will be a passive house district with 2,000 dwellings [145]. An average city receives a score of 1.4 out of a possible score of 2.0 for energy savings in buildings based on refurbishment measures and pilot buildings and/or districts that reached or neared net-zero energy targets.

A well-integrated public transport network with high levels of passenger usership is one of the most effective measures against traffic congestion with multiple benefits beyond energy and $\mathrm{CO}_{2}$ savings, including those for air quality and the quality of life. Table A3 provides an evaluation of the density of public transport, including urban rail that has an advantage in operational energy usage per passenger kilometer [146]. The average urban rail density is $0.15 \mathrm{~km} / \mathrm{km}^{2}$ with a daily ridership of 9,020 passengers 
per $\mathrm{km}$. Some cities further support the bus, trolleybus, and/or urban rail network with decentralized options based on pilot or mature bicycle sharing programs. Based on Table 4, a total of 6 cities, including Copenhagen and Helsinki, receive the highest possible score in the indicator for the density of public transport, some of which also correspond to cities with less than $25 \%$ extra traveling time due to daily congestion [147]. In contrast, traffic congestion reaches over $60 \%$ and $80 \%$ in peak morning and evening hours in Beijing and Rio de Janeiro [147].

In addition to energy and $\mathrm{CO}_{2}$ emission saving measures for the sectors of energy generation, buildings, and transport, another major domain of action and reporting in cities is public lighting. Public lighting based on solid-state lighting using Direct Current (DC) from renewable power is one of the most efficient options that are available. Amsterdam has such an implementation in the port area with both energy and material savings due to the elimination of converters and alternating current cables with plans to diffuse this measure to the rest of the city [148]. Other best practices include London that also receives a top score while the average city receives a score of 1.3 out of 2.0 in this indicator. Other cities have disadvantages, including higher electricity use per $\mathrm{km}$ of lit roads in Rio de Janeiro [149].

\section{Renewable energy potential and utilization $\left(D_{3}\right)$}

The widespread availability of renewable energy sources provides a vibrant opportunity to transform the energy base of cities. The integration of multiple renewable energy sources into urban systems can improve self-sufficiency and optimize the overall energy structure. In addition, a responsive demand side that has sufficient flexibility to follow and/or store the energy supply from variable renewables in quantity and quality across the time dimension is essential. Table 5 provides an evaluation of the renewable energy potential of cities and the current status of utilizing this potential based on the indicators in $D_{3}$. The existing gap in utilizing the renewable energy potential of cities is most evident in the cases of Batna and Lviv with shares of $1.00 \%$ and $6.54 \%$ of renewable energy in the electricity supply as well as negligible shares of green energy in the transport sector. In contrast, these and other cities have some of the highest potentials for renewable energy, including Batna that has an annual mean solar energy potential of $5,750 \mathrm{Wh} / \mathrm{m}^{2} /$ day and above average geothermal energy potential.

Based on Table 5 , an average city has an annual mean of $4,466 \mathrm{Wh} / \mathrm{m}^{2} /$ day of solar energy potential based on solar insolation on an optimally inclined plane, $4.8 \mathrm{~m} / \mathrm{s}$ of wind energy at a height of $50 \mathrm{~m}$ above ground level, and $60 \mathrm{~mW} / \mathrm{m}^{2}$ of geothermal energy based on the heat flow intensity. The average share of renewable energy in electricity production is $38.46 \%$ of which 13 cities are above this average value. The city that is closest to the average is Helsinki with a value of $39.00 \%$. In the transport sector, the average city in the sample has a share of $5.44 \%$ of green energy, including biofuels and electricity with at least a $45 \%$ renewable energy share. Among the cities in the sample, Bregenz, Copenhagen, Gothenburg, Helsinki, Rio de Janeiro, and São Paulo take place as the cities that are above the average in both indicators for renewable energy utilization. The remaining cities have mixed performances across the indicators for the share of renewable energy in the electricity and transport sectors.

As put forth in local strategies, policy efforts are ongoing to increase the penetration of renewable energy in urban energy systems, which would further increase the performance of a given city in $D_{3}$. For example, in Florence, the penetration of solar energy installations in public buildings is $9.6 \mathrm{~kW}$ per 100 inhabitants that is low in comparison to other Italian cities [150]. Under on-going measures in its SEAP, Florence seeks to change this situation with a target of applying PV and/or solar thermal units to at least $10 \%$ of building structures [82]. The utilization of renewable energy sources to obtain energy outputs with a high useful work potential (exergy) is prioritized in $D_{3}$ while 
the cascaded use of renewable energy to lower exergy demands will produce additional benefits for $\mathrm{CO}_{2}$ emission savings as captured in $D_{5}$. In addition, the use of wind energy and solar PV technologies has the potential of displacing about 2,500 litres of water consumption per MWh that would have been used in coal or nuclear based power plants [151]. Renewable energy thereby has a central role in addressing multiple domains in the Sustainable Development Goals [152].

Table 5. Data inputs to the renewable energy potential and utilization dimension $\left(D_{3}\right)$

\begin{tabular}{|c|c|c|c|c|c|}
\hline City $\left(C_{j}\right)$ & $\begin{array}{c}\text { Solar energy } \\
\text { potential } \\
{\left[\mathrm{Wh} / \mathrm{m}^{2} / \text { day }\right]^{\mathrm{a}}}\end{array}$ & $\begin{array}{l}\text { Wind energy } \\
\text { potential }[\mathrm{m} / \mathrm{s}]^{\mathrm{a}}\end{array}$ & $\begin{array}{l}\text { Geothermal energy } \\
\text { potential }\left[\mathrm{mW} / \mathrm{m}^{2}\right]^{\mathrm{b}}\end{array}$ & $\begin{array}{c}\text { Renewable } \\
\text { energy in electricity } \\
\text { production }[\%]^{\mathrm{c}}\end{array}$ & $\begin{array}{l}\text { Green energy in } \\
\text { transport [\%] }\end{array}$ \\
\hline Data sources & [153] & [154] & [155] & [156] & {$[157]$} \\
\hline Amsterdam & 3,440 & 6.3 & 76 & 13.46 & 3.39 \\
\hline Antwerp & 3,470 & 5.9 & 76 & 17.79 & 4.56 \\
\hline Bangalore & 5,930 & 3.9 & 36 & 14.95 & 0.44 \\
\hline Batna & 5,750 & 4.1 & 65 & 1.00 & 0.00 \\
\hline Beijing & 4,780 & 4.2 & 56 & 25.75 & 0.63 \\
\hline Berlin & 3,450 & 4.4 & 65 & 30.05 & 5.07 \\
\hline Bilbao & 4,090 & 3.8 & 65 & 40.08 & 3.40 \\
\hline Braga & 5,100 & 4.9 & 65 & 55.15 & 5.28 \\
\hline Bregenz & 3,790 & 4.3 & 65 & 81.00 & 10.41 \\
\hline Bydgoszcz & 3,450 & 5.0 & 40 & 15.45 & 4.51 \\
\hline Copenhagen & 3,530 & 6.6 & 65 & 56.00 & 6.58 \\
\hline Florence & 4,790 & 3.9 & 90 & 37.27 & 2.88 \\
\hline Gothenburg & 3,650 & 6.2 & 40 & 57.22 & 14.34 \\
\hline Grand Lyon & 4,210 & 5.5 & 86 & 18.13 & 6.67 \\
\hline Helsinki & 3,070 & 6.5 & 40 & 39.00 & 12.04 \\
\hline Karlovac & 4,120 & 4.9 & 56 & 74.00 & 2.60 \\
\hline London & 3,560 & 5.3 & 56 & 25.60 & 2.83 \\
\hline Lviv & 3,470 & 4.6 & 56 & 6.54 & 0.40 \\
\hline Madrid & 5,680 & 4.3 & 76 & 40.08 & 4.68 \\
\hline Porto & 5,470 & 4.9 & 65 & 55.15 & 5.28 \\
\hline Rio de Janeiro & 5,910 & 4.1 & 56 & 81.19 & 17.87 \\
\hline Salé & 6,160 & 4.5 & 65 & 12.00 & 0.00 \\
\hline São Paulo & 5,910 & 3.4 & 56 & 81.19 & 17.87 \\
\hline Tianjin & 4,710 & 4.4 & 36 & 25.75 & 0.63 \\
\hline Vila Nova de Gaia & 5,500 & 5.1 & 65 & 55.15 & 5.28 \\
\hline Vilnius & 3,130 & 4.8 & 40 & 41.00 & 3.83 \\
\hline Sample average & 4,466 & 4.8 & 60 & 38.46 & 5.44 \\
\hline
\end{tabular}

\section{Water usage and environmental quality $\left(D_{4}\right)$}

Levels of water usage in cities can either prevent or necessitate undertakings to expand the water supply network and tap into the use of additional limited water resources. For this reason, the ability to manage water consumption by increasing the efficiency of water usage and recycling water resources becomes crucial. Already, some cities are targeting to have at most zero increases in potable water usage as a model for other cities to follow [158]. In the present sample, the performance of an average city indicates a water usage of $7.9 \mathrm{~m}^{3}$ per capita when measured based on the blue water footprint of domestic consumption, which excludes green and grey water footprints as well as any blue water that may be used for products consumed elsewhere [159]. In Grand Lyon, for example, the blue water footprint of domestic consumption is $11.3 \mathrm{~m}^{3}$ per capita [160] that is higher than other localities in France and the majority of other values in the sample. In contrast, the value is still more favourable than the per capita values of $14.0 \mathrm{~m}^{3}$ in Florence and $12.2 \mathrm{~m}^{3}$ in Gothenburg.

Aspects of water usage are interlinked with aspects of water quality in such a way that the excessive extraction of resources from water reservoirs can reduce the dilution capacity of water bodies and deteriorate water quality while posing critical issues of 
water stress. In contrast, the recycling of stormwater and wastewater can improve waterway health and in so doing, also benefit other cities that may share the same water basins [161]. Based on measurements of nitrogen, potassium, $\mathrm{pH}$, conductivity, and dissolved oxygen, the value of the water quality index [162] in an average city is 81.8 out of a possible score of 100 . Overall, 14 cities are at or above while 12 cities are below this average with the highest and lowest values being put forth by Helsinki with a value of 99.1 and Batna with a value of 37.7, respectively. An important source of water for Helsinki comes from Lake Päijänne that is treated and then distributed to homes. In the past decades, an extensive effort to limit the flow of chemicals from agriculture and pulp industries to water bodies was put forth to obtain the present levels of water quality [163]. In contrast, the operation of the wastewater treatment plant of Batna is currently suboptimal among other issues, including impact from the contaminant load of the industry [164] that continues to impact overall water quality.

Based on readings from urban monitoring stations for the two most recent data series [165-166], Braga, Bilbao, and Rio de Janeiro recorded the most improvement in annual mean $\mathrm{PM}_{10}$ values. In these cities, the annual mean $\mathrm{PM}_{10}$ values improved by more than $25 \%$ from the values in the previous data series. In Rio de Janeiro, the previous reading was $67.0 \mu \mathrm{g} / \mathrm{m}^{3}$ [165] while the most recent reading from the same urban monitoring stations is given to be $48.8 \mu \mathrm{g} / \mathrm{m}^{3}$ [166]. Other cities marked less of an improvement, including Beijing that was able to improve an extreme value of $121 \mu \mathrm{g} / \mathrm{m}^{3}$ [165] to only $108.0 \mu \mathrm{g} / \mathrm{m}^{3}$ [166]. Coal burning in the urban areas of Beijing was officially banned while increasing rates of car ownership in the city and industrialization in the neighbouring areas continue to affect air quality [167].

All cities, however, did not record improvements in values among which at least 8 cities had degradation of annual mean $\mathrm{PM}_{10}$ concentration values. Those of Tianjin degraded from $96 \mu \mathrm{g} / \mathrm{m}^{3}$ [165] to more than $125 \mu \mathrm{g} / \mathrm{m}^{3}$ [166] and similarly, those of Bangalore deteriorated from $103.3 \mu \mathrm{g} / \mathrm{m}^{3}$ [165] to $118.1 \mu \mathrm{g} / \mathrm{m}^{3}$ [166]. Based on Table 6 , annual mean $\mathrm{PM}_{10}$ concentration across all 26 cities in the sample is $39.7 \mu \mathrm{g} / \mathrm{m}^{3}$ or $26.3 \mu \mathrm{g} / \mathrm{m}^{3}$ with the winsorized values of 4 outlier values. The ability to obtain further improvements in annual mean $\mathrm{PM}_{10}$ values of which $70 \%$ may be attributed to $\mathrm{PM}_{2.5}$ concentrations is crucial given that each $5 \mu \mathrm{g} / \mathrm{m}^{3}$ increase in $\mathrm{PM}_{2.5}$ can lead to a $20 \%$ higher risk of developing deposits in coronary arteries [168] that trigger coronary diseases as a major public health concern.

Stress on environmental quality is further imposed based on the demand for land area to support the current levels of food and material consumption in society. The ecological footprint method quantifies the demand for land across six categories [169], including those for built-up land and various kinds of agricultural produce. The average level of ecological footprint in the sample is 4.36 global hectares (gha) per capita, which indicate the area that is needed to support the annual consumption pattern of one individual. The per capita values for the two Chinese cities of Beijing at 3.92 gha and Tianjin at 2.88 gha [170] compare differently with the national value at 3.49 gha per capita while both values are below the sample average. In comparison to biocapacity as the capacity of natural systems to regenerate, the average ecological deficit in the sample is 1.15 gha per capita.

Such an ecological deficit further underlines the need for a rapid transformation to more sustainable production and consumption patterns, including those through such paradigm shifts as the shared economy. In the metropolitan area of Helsinki, for example, only $4 \%$ of private vehicles are found to be necessary to sustain current levels of vehicle transport considering shared mobility schemes [171]. In addition, as shared mobility is able to replace all private car journeys, $\mathrm{CO}_{2}$ emissions could be curbed by about $34 \%$ and the land for public parking could be utilized for productive purposes [171]. Such analyses exemplify the co-benefits of shared mobility alongside those for reduced congestion. 
Table 6. Data inputs to the water usage and environmental quality dimension $\left(D_{4}\right)$

\begin{tabular}{|c|c|c|c|c|c|}
\hline City $\left(C_{j}\right)$ & $\begin{array}{l}\text { Domestic water } \\
\text { consumption per } \\
\text { capita }\left[\mathrm{m}^{3}\right]\end{array}$ & $\begin{array}{l}\text { Water quality } \\
\text { index [/100] }\end{array}$ & $\begin{array}{c}\text { Annual } \\
\text { mean } \mathrm{PM}_{10} \\
\text { concentration } \\
{\left[\mu \mathrm{g} / \mathrm{m}^{3}\right]}\end{array}$ & $\begin{array}{c}\text { Ecological footprint } \\
\text { per capita [gha] }\end{array}$ & $\begin{array}{c}\text { Biocapacity } \\
\text { per capita [gha] }\end{array}$ \\
\hline Data sources & {$[172,173]$} & {$[174,175]$} & [166] & {$[176]$} & {$[176]$} \\
\hline Amsterdam & 3.1 & 78.5 & 23.1 & 5.80 & 1.12 \\
\hline Antwerp & 7.1 & 75.7 & 26.7 & 6.89 & 1.13 \\
\hline Bangalore & 5.0 & 80.6 & 118.1 & 1.06 & 0.44 \\
\hline Batna & 4.3 & 37.7 & 78.1 & 2.38 & 0.59 \\
\hline Beijing & 5.3 & 76.4 & 108.0 & 3.92 & 0.93 \\
\hline Berlin & 7.1 & 85.6 & 24.2 & 5.46 & 2.25 \\
\hline Bilbao & 11.7 & 81.8 & 19.5 & 4.03 & 1.58 \\
\hline Braga & 10.5 & 91.7 & 12.0 & 3.87 & 1.53 \\
\hline Bregenz & 9.2 & 75.9 & 19.0 & 6.11 & 3.00 \\
\hline Bydgoszcz & 5.5 & 80.8 & 34.9 & 4.27 & 1.99 \\
\hline Copenhagen & 7.7 & 81.5 & 26.5 & 6.11 & 4.57 \\
\hline Florence & 14.0 & 95.7 & 26.0 & 4.50 & 1.05 \\
\hline Gothenburg & 12.2 & 96.7 & 18.6 & 6.53 & 10.41 \\
\hline Grand Lyon & 11.3 & 77.4 & 22.0 & 5.06 & 2.91 \\
\hline Helsinki & 6.6 & 99.1 & 19.1 & 6.73 & 13.34 \\
\hline Karlovac & 9.7 & 90.4 & 26.4 & 3.77 & 2.79 \\
\hline London & 3.5 & 90.5 & 28.1 & 4.96 & 1.27 \\
\hline Lviv & 9.4 & 58.9 & 47.4 & 3.24 & 2.52 \\
\hline Madrid & 11.7 & 81.8 & 18.7 & 4.03 & 1.58 \\
\hline Porto & 10.5 & 91.7 & 24.6 & 3.87 & 1.53 \\
\hline Rio de Janeiro & 6.9 & 84.3 & 48.8 & 3.02 & 8.85 \\
\hline Salé & 4.2 & 65.1 & 31.0 & 1.70 & 0.80 \\
\hline São Paulo & 6.9 & 84.3 & 35.3 & 3.02 & 8.85 \\
\hline Tianjin & 5.3 & 76.4 & 150.0 & 2.88 & 0.93 \\
\hline Vila Nova de Gaia & 10.5 & 91.7 & 20.8 & 3.87 & 1.53 \\
\hline Vilnius & 6.0 & 97.7 & 26.6 & 6.18 & 5.99 \\
\hline Sample average & 7.9 & 81.8 & 39.7 & 4.36 & 3.21 \\
\hline
\end{tabular}

\section{$\mathrm{CO}_{2}$ emissions and industrial profile $\left(\mathrm{D}_{5}\right)$}

The decarbonisation of urban systems based on the use of renewable energy in the urban context in buildings, transport, and the industry remains to be a challenge around the world although progress is being made. For example, among the cities in the present sample, the urban and inter-city rail network of Amsterdam as well as other Dutch cities is now supplied with $100 \%$ renewable energy [177] while the built area surfaces of urban rail stations in Antwerp [178] are being used for building-integrated photovoltaics. In contrast, the energy system of Amsterdam is largely based on the use of natural gas for individual space heating of buildings. This represents a thermodynamic mismatch with ramifications on additional primary energy spending as well as $\mathrm{CO}_{2}$ emissions [179]. By the year 2020, however, the city has plans in place to realize an efficient expansion in the district heating network with close to a doubling of buildings that are connected to a district energy scheme [63]. The integration of renewable energy in urban waterworks also presents opportunities for cities.

Table 7 provides the data compilation for the indicators in $D_{5}$ and represents the most recent status of $\mathrm{CO}_{2}$ emissions for the cities in the sample. Based on monitoring reports submitted under the CoM [180] or local statistical yearbooks, an average city in the sample emitted 9.21 million tonnes of $\mathrm{CO}_{2}$ emissions from buildings and 2.98 million tonnes of $\mathrm{CO}_{2}$ emissions from transport. Including all other sectors except industries that may be included in EU ETS, which is not reported in the framework of the CoM, an average city emitted 0.28 tonnes of $\mathrm{CO}_{2}$ emissions per $\mathrm{MWh}$. One of the cities that appear to be closest to reaching a complete decarbonisation of the energy sector based on a relatively lower $\mathrm{CO}_{2}$ intensity is Gothenburg that emits 0.13 tonnes of $\mathrm{CO}_{2}$ per $\mathrm{MWh}$ [86]. Another example may be given from Copenhagen that currently emits about 0.17 tonnes of $\mathrm{CO}_{2}$ per MWh [81]. 
The presence of industry in the urban context may be a disadvantage for present levels of energy spending and $\mathrm{CO}_{2}$ emissions. Based on Table A4, 15 cities had 4 or more energy and $\mathrm{CO}_{2}$ intense industries and/or clusters located within the urban context. The utilization of residual heat from industry that is in proximity to urban areas with greater than $50 \mathrm{TJ} / \mathrm{km}^{2}$ of heat demand density, however, can provide a promising opportunity to substitute primary energy spending in the energy supply structure of cities [181]. For example, the residual heat of two thermal power plants with the main activity of electricity generation that is less than $10 \mathrm{~km}$ from central Amsterdam can provide 24.91 TJ of heat on an annual basis [182]. Among other industries, the non-ferrous metals industry that is located in close proximity to Antwerp can provide $0.77 \mathrm{TJ}$ of heat on an annual basis. According to such results from the Heat Roadmap Europe Pan-European Thermal Atlas (Peta) 4.2 [182], a significant share of current primary energy spending can be substituted based on residual heat from industry.

In addition, it is important that airports servicing the cities are included in the scope of urban energy systems, especially since the energy and $\mathrm{CO}_{2}$ emissions impact of airports can often exceed those of particular districts of the city. Airports that have undertaken measures for on-site renewable energy generation and smart grid applications as well as innovative energy harvesting measures such as those in [183] obtain an advantage over other airports in which such implementations may not have been undertaken. The pilot power-to-gas facility in one of the airports of Berlin, namely Brandenburg Airport, started to use wind and solar energy to power a $500 \mathrm{~kW}$ alkaline electrolyser to produce hydrogen gas. The gas is then used for the energy needs of transport on the groundside as well as cogeneration in the terminals [184]. In total, the 3 airports that are certified with climate neutrality under Airport Carbon Accreditation (ACA) have best practices in the uses of renewable energy. For example, Bangalore Kempegowda International Airport is increasing on-site electricity generation based on solar energy towards a 50\% renewable energy share [185]. Similarly, Helsinki Airport now has the largest solar power plant among Nordic airports [186].

Table 7. Data inputs to the $\mathrm{CO}_{2}$ emissions and industrial profile dimension $\left(D_{5}\right)$

\begin{tabular}{|c|c|c|c|c|c|}
\hline City $\left(C_{j}\right)$ & $\begin{array}{c}\mathrm{CO}_{2} \text { emissions of } \\
\text { buildings } \\
{\left[\mathrm{t} \mathrm{CO}_{2}\right]}\end{array}$ & $\begin{array}{c}\mathrm{CO}_{2} \text { emissions } \\
\text { of transport } \\
{\left[\mathrm{t} \mathrm{CO}_{2}\right]}\end{array}$ & $\begin{array}{c}\text { Average } \\
\mathrm{CO}_{2} \text { intensity } \\
{\left[\mathrm{t} \mathrm{CO}_{2} / \mathrm{MWh}\right]}\end{array}$ & $\begin{array}{l}\text { Number of } \\
\mathrm{CO}_{2} \text { intense } \\
\text { industries }\end{array}$ & $\begin{array}{l}\text { Airport ACA level and } \\
\text { measures }^{c}\end{array}$ \\
\hline Data sources & Table $2^{\mathrm{a}}$ & Table $2^{\mathrm{a}}$ & Table $2^{\mathrm{a}}$ & Table A4 & [187] \\
\hline Amsterdam & $3,770,890$ & 779,110 & 0.30 & 5 & 4 \\
\hline Antwerp & $2,093,000$ & 934,000 & 0.24 & 7 & 3 \\
\hline Bangalore & $8,082,500$ & $2,087,500$ & 0.16 & 5 & 4 \\
\hline Batna & 784,000 & 452,000 & 0.30 & 2 & 0 \\
\hline Beijing & $83,547,470$ & $21,912,000$ & 0.58 & 8 & 1 \\
\hline Berlin & $10,730,129$ & $4,495,000$ & 0.30 & 6 & 1 \\
\hline Bilbao & 595,802 & 516,629 & 0.29 & 2 & 0 \\
\hline Braga & 235,582 & 175,433 & 0.22 & 2 & 2 \\
\hline Bregenz & 62,977 & 41,328 & 0.31 & 2 & 3 \\
\hline Bydgoszcz & $1,219,054$ & 726,465 & 0.39 & 3 & 0 \\
\hline Copenhagen & $1,030,617$ & 339,446 & 0.17 & 3 & 3 \\
\hline Florence & 859,826 & 606,967 & 0.25 & 3 & 0 \\
\hline Gothenburg & 563,000 & 704,951 & 0.13 & 5 & 3 \\
\hline Grand Lyon & $2,425,000$ & $1,841,000$ & 0.18 & 4 & 3 \\
\hline Helsinki & $1,849,000$ & 607,000 & 0.19 & 4 & 4 \\
\hline Karlovac & 79,237 & 32,551 & 0.20 & 3 & 2 \\
\hline London & $29,240,000$ & $7,610,000$ & 0.28 & 4 & 3 \\
\hline Lviv & $2,913,532$ & 508,899 & 0.35 & 3 & 0 \\
\hline Madrid & $5,458,000$ & $2,240,000$ & 0.29 & 4 & 2 \\
\hline Porto & 675,751 & 429,869 & 0.32 & 5 & 2 \\
\hline Rio de Janeiro & $4,077,360$ & $4,940,700$ & 0.24 & 4 & 0 \\
\hline Salé & 386,219 & 322,058 & 0.33 & 4 & 0 \\
\hline São Paulo & $2,486,213$ & $9,810,741$ & 0.17 & 4 & 0 \\
\hline Tianjin & $75,023,736$ & $14,104,659$ & 0.59 & 8 & 1 \\
\hline Vila Nova de Gaia & 420,745 & 463,728 & 0.21 & 2 & 2 \\
\hline Vilnius & 903,811 & 807,786 & 0.22 & 2 & 1 \\
\hline Sample average & $9,212,056$ & $2,980,378$ & 0.28 & 4.0 & 1.7 \\
\hline \multicolumn{6}{|c|}{$\begin{array}{l}\text { a Calculated from SEAP or equivalent plans based on references in Table } 2[59-116] \\
\left.{ }^{\mathrm{D}} \text { Includes sectors that require high-temperature processes (e.g. kiln heating up to } 2,000{ }^{\circ} \mathrm{C}\right) \text { [188], see Table A4 } \\
{ }^{\mathrm{c}} \text { Scores greater than } 3 \text { require renewable energy best practices on the land side, air side and/or ground side }\end{array}$} \\
\hline & & 5 & & & \\
\hline
\end{tabular}




\section{Urban planning and social welfare $\left(D_{6}\right)$}

The planning of urban systems towards cleaner and more liveable cities is an important component of optimizing the interactions between people, technology and the environment in the context of cities as complex systems. More liveable cities are dependent on multiple aspects including urban infrastructure, urban form, green spaces, and social welfare [189]. In this respect, infrastructure for urban waste and wastewater management enables an essential urban service that can also support the transition to a more resource-efficient, closed-loop society. As amended under the Circular Economy Package [190], it is expected that at least $65 \%$ of municipal waste is recycled by the year 2035 while at most $10 \%$ will be landfilled towards zero waste. The Urban Waste Water Treatment Directive [191] stipulates limits for compliance in collecting, treating, and discharging subjected wastewater loads.

Based on the data compilation for the sub-indicators in Table A5, an average city in the sample has a recycling and composting share of $30 \%$. Recycling and composting can take place among the most environmentally friendly options in waste management [192]. The leading cities are Berlin (68\%), Bregenz (67\%) and Antwerp (63\%) while the lagging cities are Batna, Beijing, Lviv, Rio de Janeiro, São Paulo, and Tianjin with a share of $5 \%$ or less. In contrast, separate waste collection is a critical basis for increasing the share of recycling and composting in the waste hierarchy towards zero waste municipalities [193]. The cities with relatively higher recycling and composting shares, however, are not always the cities with the lowest waste generation per capita, both of which are important according to the principles of waste hierarchy. In the present sample, an average city produces $398 \mathrm{~kg}$ of waste per capita. Berlin, Copenhagen, and Helsinki take place as the cities that have below average waste production per capita as well as recycling and composting shares above $40 \%$.

The level of compliance with the Urban Waste Water Treatment Directive is improving with deficiencies in about $12 \%$ of cases for more stringent treatment [191]. Among cities in the sample, the evaluation of the compliance summaries of wastewater treatment plants indicates that those of 17 cities are directly compliant based on levels of Biochemical (BOD) and Chemical (COD) Oxygen Demand as well as Total Dissolved Solids (TSS) in treated wastewater [194]. Moreover, important amounts of nutrients can be recovered from municipal wastewater streams based on nutrient recycling programs. Some cities, including Amsterdam, Helsinki and Grand Lyon, treat 100\% of wastewater with nutrient recovery techniques to recover nitrogen, potassium, and/or phosphorus as chemical commodity [195]. In other cities, selected wastewater treatment plants are found to have non-compliances in certain parameters as well as partial collection of the wastewater load as given in Table A6. For example, Vila Nova de Gaia generates 28,000 population equivalents wastewater load while primary and secondary treatment is not compliant with criteria, including BOD [191].

Important parameters to distinguish aspects of compact urban form include the number of non-continuous urban centers, the share of the population living in core urban areas, and the sprawl index [196]. Cities that have polycentricism, a relatively high concentration of inhabitants in core urban areas, and sprawl index far less than zero can be more efficient and pose less of a threat on land-use changes through compact urban form [197] in contrast to cities in which these conditions are the opposite. Urban intensification that prioritizes the development of central nodes has been pursued as a strategy to increase the quality of life through more compact urban form in such cities as Gothenburg [198]. In fact, the city has managed to achieve a negative sprawl index at $-1.97 \%$ with $56.15 \%$ of the population living in core urban areas [196]. In contrast, the highest urban sprawl is seen to take place in Madrid at 4.57\%, followed by Porto that has a similarly high sprawl index at $4.30 \%$ [196]. 
The allotment of green space and the protection of green corridors are other priorities that must be undertaken simultaneously while intensifying urban development [199]. In the present sample, 5 cities have green area as a share of total urban area at or above $40 \%$. Green areas also limit the share of impermeable surfaces in the city as an important climate adaptation measure to reduce the risks of inundation and heat waves. For example, the share of green area is $53.71 \%$ while impermeable surfaces are $28.85 \%$ [200] in Gothenburg that seeks to be a Water-Wise city [201]. The area of protected green corridors within a $150 \mathrm{~km}$ radius of the city, including national parks, nature reserves, and Ramsar Convention sites is evaluated for all cities. Amsterdam has the greatest diversity of such sites with over $3,184 \mathrm{~km}^{2}$ of protected land area. Based on Table A7, cities with both favourable compact urban form and green areas include Amsterdam and Gothenburg while an average city scores 1.8 .

In relatively more liveable cities, quality of life is further shaped by the availability of economic and educational opportunities, including income and perceptions of well-being [202]. Based on the values in Table 8, an average city in the sample had a Gross Domestic Product (GDP) of 30,969 PPP USD per capita at 2010 constant prices. In addition, an average citizen scored satisfaction with daily experience at 7.2 out of 10 when adjusted based on inequality. On average, $32.5 \%$ of the population had attained the level of tertiary education, which can increase employment opportunities [203]. Cities that receive a higher standing in such parameters of social welfare in Table 8 are Gothenburg, London, and Copenhagen.

Table 8. Data inputs to the urban planning and social welfare dimension $\left(D_{6}\right)$

\begin{tabular}{|c|c|c|c|c|c|}
\hline City $\left(C_{j}\right)$ & $\begin{array}{c}\text { Waste and } \\
\text { wastewater } \\
\text { management }^{\mathrm{a}}\end{array}$ & $\begin{array}{l}\text { Compact urban } \\
\text { form and green } \\
\text { spaces }^{b}\end{array}$ & $\begin{array}{c}\text { GDP per capita } \\
\text { [PPP USD } \\
\text { national] }\end{array}$ & $\begin{array}{l}\text { Inequality adjusted } \\
\text { well-being [/10] }\end{array}$ & $\begin{array}{l}\text { Tertiary } \\
\text { education } \\
\text { rate }[\%]\end{array}$ \\
\hline Data sources & [204-210] & {$[196,211-213]$} & [214] & [215] & [216-218] \\
\hline Amsterdam & 5.5 & 2.3 & 50,898 & 7.7 & 45.7 \\
\hline Antwerp & 6.3 & 1.3 & 46,383 & 7.3 & 45.6 \\
\hline Bangalore & 2.3 & 1.0 & 6,572 & 6.9 & 10.2 \\
\hline Batna & 2.0 & 1.3 & 15,075 & 6.7 & 9.0 \\
\hline Beijing & 4.3 & 1.3 & 15,535 & 7.6 & 11.7 \\
\hline Berlin & 6.6 & 2.3 & 48,730 & 7.4 & 33.2 \\
\hline Bilbao & 5.1 & 2.0 & 36,310 & 7.0 & 40.1 \\
\hline Braga & 5.2 & 2.0 & 30,624 & 7.1 & 34.6 \\
\hline Bregenz & 6.5 & 1.7 & 50,078 & 7.7 & 40.1 \\
\hline Bydgoszcz & 5.5 & 2.0 & 27,811 & 7.1 & 44.6 \\
\hline Copenhagen & 5.8 & 2.0 & 49,696 & 7.9 & 47.7 \\
\hline Florence & 5.4 & 1.7 & 38,161 & 7.1 & 26.2 \\
\hline Gothenburg & 5.8 & 2.3 & 49,175 & 7.9 & 51.0 \\
\hline Grand Lyon & 5.4 & 2.0 & 41,466 & 7.0 & 43.6 \\
\hline Helsinki & 5.8 & 2.0 & 43,053 & 7.8 & 46.1 \\
\hline Karlovac & 4.9 & 2.3 & 23,596 & 6.2 & 32.2 \\
\hline London & 4.9 & 2.7 & 42,609 & 7.4 & 48.1 \\
\hline Lviv & 3.5 & 1.7 & 8,272 & 6.6 & 20.5 \\
\hline Madrid & 5.3 & 2.0 & 36,310 & 7.0 & 40.1 \\
\hline Porto & 5.2 & 2.0 & 30,624 & 7.1 & 34.6 \\
\hline Rio de Janeiro & 2.7 & 2.0 & 15,128 & 7.5 & 14.0 \\
\hline Salé & 1.9 & 1.0 & 7,838 & 7.0 & 6.6 \\
\hline São Paulo & 2.7 & 2.0 & 15,128 & 7.5 & 14.0 \\
\hline Tianjin & 4.0 & 1.0 & 15,535 & 7.6 & 11.7 \\
\hline Vila Nova de Gaia & 4.2 & 2.0 & 30,624 & 7.1 & 34.6 \\
\hline Vilnius & 4.8 & 2.0 & 29,966 & 6.2 & 58.7 \\
\hline Sample average & 4.7 & 1.8 & 30,969 & 7.2 & 32.5 \\
\hline
\end{tabular}




\section{$R \& D$, innovation and sustainability policy $\left(D_{7}\right)$}

The cross-cutting field of R\&D, innovation and sustainability policy can support the performance of a given city in the above indicators given that the knowledge base of local stakeholders are integrated with the measures in related strategies, including Sustainable Urban Mobility Plans. First, for such a synergetic context, priorities in energy, transport, the environment, as well as smart and sustainable cities must be upheld in the strategies of the R\&D and innovation systems in which the local stakeholders interact. Table A8 provides an evaluation of the R\&D and innovation policy orientation within a multi-level governance framework [219] based on related priorities and the resources that are available for their implementation. Policy tools include the City of the Future initiative for German cities [220], including Berlin, and the support of the Ministry of Cities in Brazil for low-carbon transport [221], including Rio de Janeiro and São Paulo. Furthermore, at least 8 cities are demonstration sites of European smart city projects [222]. The highest gross domestic expenditure on R\&D (GERD) as a percentage of GDP is $3.27 \%$ while the average is $1.69 \%$.

Clean technology patents that are classified with the codes Y02 and Y04 [223] are one of the outputs of the functions of R\&D and innovation systems. These patents include those on building technologies (Y02B), energy generation (Y02E), transport (Y02T), smart grids (Y04S), as well as carbon capture and storage (Y02C) [223]. Based on Table A9, the largest quantity of clean technology patents belong to Germany while the highest share of Y02 and Y04 coded patents in total national patents belongs to Morocco. In addition, Copenhagen and Paris act as hubs of innovation in their countries given that more than $35 \%$ of international patent applications have applicants located in these cities [196]. Copenhagen contributes to the international patent applications of Denmark with a share of 55\% [196].

The presence of local universities and research institutes are further assets for the local knowledge base. Table A10 identifies the strength of cities based on the presence of institutes of higher education and research in the city. The quality of education and research are further integrated into the evaluations based on a weighted scoring for institutions from the city that take place in the top 1,000 institution rankings of SCImago [224]. The SCImago institution rankings are based on excellent performance in research, innovation outputs, and societal impact [225]. The cities with the greatest advantage in the local knowledge base include the cities of London, Beijing and Tianjin. In addition, the sustainable city initiatives of Amsterdam are supported by the Amsterdam Institute for Metropolitan Solutions that aims to bring the city closer to the principles of a circular economy [226]. In contrast, extended collaboration networks and knowledge transfer becomes increasingly important for cities that may not have similar assets in local knowledge production. Cities that may be seen to include weaknesses in both local institutes and the $h$-index include Batna and Lviv.

Based on Table 9, an average city in $D_{7}$ receives a score of 2.2 out of 3.0 in R\&D and innovation policy orientation and 2.1 out of 3.0 in clean technology patents. In addition, an average city has about 6 universities of which 4 takes place in the SCImago rankings. The strength of knowledge production as further represented by the $h$-index is an average value of 562. Overall, the assets that are available to transform cities into hubs of sustainable innovation must be orchestrated to support the $\mathrm{CO}_{2}$ mitigation targets of cities for the year 2020 and beyond. In an average city, the target is to reduce $\mathrm{CO}_{2}$ emissions by $25 \%$ from the baseline by the year 2020 , including the annualized value of targets that are set beyond 2020. The highest target is the target of Copenhagen in which the city will be climate neutral by the year 2025 [79] that requires an annualized reduction of at least $67 \%$ by the year 2020 . 
Table 9. Data inputs to the R\&D, innovation and sustainability policy dimension $\left(D_{7}\right)$

\begin{tabular}{|c|c|c|c|c|c|}
\hline City $\left(C_{j}\right)$ & $\begin{array}{l}\mathrm{R} \& \mathrm{D} \text { and innovation } \\
\text { policy orientation }^{\mathrm{a}}\end{array}$ & $\begin{array}{c}\text { National } \\
\text { patents in clean } \\
\text { technologies }^{\mathrm{b}}\end{array}$ & $\begin{array}{c}\text { Universities/ } \\
\text { institutes in the local } \\
\text { ecosystem }^{\mathrm{c}}\end{array}$ & $\begin{array}{l}\text { National } \\
h \text {-index }\end{array}$ & $\begin{array}{c}\text { Reduction } \\
\text { target for } \mathrm{CO}_{2} \text { emissions }\end{array}$ \\
\hline Data sources & [227-228] & [229] & [224] & [230] & {$[11,12]$} \\
\hline Antwerp & 2.0 & 2.0 & 6 & 661 & 20 \\
\hline Bangalore & 2.0 & 2.5 & 12 & 478 & 0 \\
\hline Batna & 1.0 & 1.5 & 3 & 125 & 20 \\
\hline Bilbao & 1.5 & 2.0 & 3 & 723 & 31 \\
\hline Braga & 2.0 & 2.0 & 3 & 379 & 20 \\
\hline Bregenz & 3.0 & 2.0 & 1 & 540 & 21 \\
\hline Bydgoszcz & 2.0 & 1.5 & 3 & 445 & 22 \\
\hline Copenhagen & 3.0 & 2.0 & 6 & 619 & 67 \\
\hline Florence & 2.0 & 2.0 & 3 & 839 & 20 \\
\hline London & 2.0 & 2.5 & 39 & 1213 & 38 \\
\hline Lviv & 1.5 & 1.5 & 6 & 211 & 21 \\
\hline Madrid & 1.5 & 2.0 & 13 & 723 & 20 \\
\hline Porto & 2.0 & 2.0 & 9 & 379 & 45 \\
\hline Rio de Janeiro & 2.5 & 2.5 & 15 & 461 & 20 \\
\hline Salé & 1.5 & 2.0 & 3 & 151 & 20 \\
\hline São Paulo & 2.5 & 2.5 & 12 & 461 & 20 \\
\hline Tianjin & 2.5 & 3.0 & 30 & 655 & 0 \\
\hline Vila Nova de Gaia & 2.0 & 2.0 & 9 & 379 & 25 \\
\hline Vilnius & 2.0 & 1.5 & 4 & 165 & 26 \\
\hline Sample average & 2.2 & 2.1 & 10 & 562 & 25 \\
\hline
\end{tabular}

\section{RESULTS AND DISCUSSION}

The data inputs in Tables 3-9 provide the basis to apply the SDEWES Index to the present sample of 26 cities as provided in this section. The results are discussed based on quartiles of performance and compared based on ratios with the sample average $C_{A V}$ per each dimension (Figures 2-8). In addition, results from 10,000 Monte Carlo experiments are compared while an application of a normative scenario for Rio de Janeiro is provided.

\section{Results for energy usage and climate}

Figure 2 provides the normalized values of the indicators in $D_{1}$ for the 26 cities in the current sample. These normalized values represent the total unweighted scores for $D_{1}$ prior to the index aggregation in eq. (1). These values are further organized into quartiles in which the top performing cities that take place in the top $25 \%$ of these values are marked within the range for $Q_{4}$. Accordingly, the top performing cities in $D_{1}$ based on aspects of energy usage and climate in descending order are Salé (40.571), Karlovac (40.278), Bregenz (40.042), and Vilnius (38.971). Among these cities, Karlovac gained an advantage in $D_{1}$ during the most recent monitoring phase that indicated over a $40 \%$ reduction in the energy usage of buildings and $9.7 \%$ reduction in the energy usage of transport from the baseline year [95]. On a per capita basis, energy usage decreased from 18.08 MWh to 10.21 MWh [95]. The cities of Batna and Bilbao also take place in $Q_{4}$.

Considering all cities in Figure 2, the sample average $C_{A V}$ for $D_{1}$ is marked in the last stacked bar at a value of 31.052 and extended with a dotted line as a reference value for the other cities. In comparison to this reference value, the ratios of the values $C_{j}$ over $C_{A V}$ range between 1.31 and 0.44 as given in the triangular markings. In the latter case, the city of Tianjin performs below the average in most indicators, including energy usage per capita based on a value of $39.73 \mathrm{MWh}$ per capita and a final to primary energy ratio of $68.1 \%$. Cities that minimize energy usage in buildings and transport relative to both population and climate with a favourable energy system efficiency perform better in $D_{1}$. 


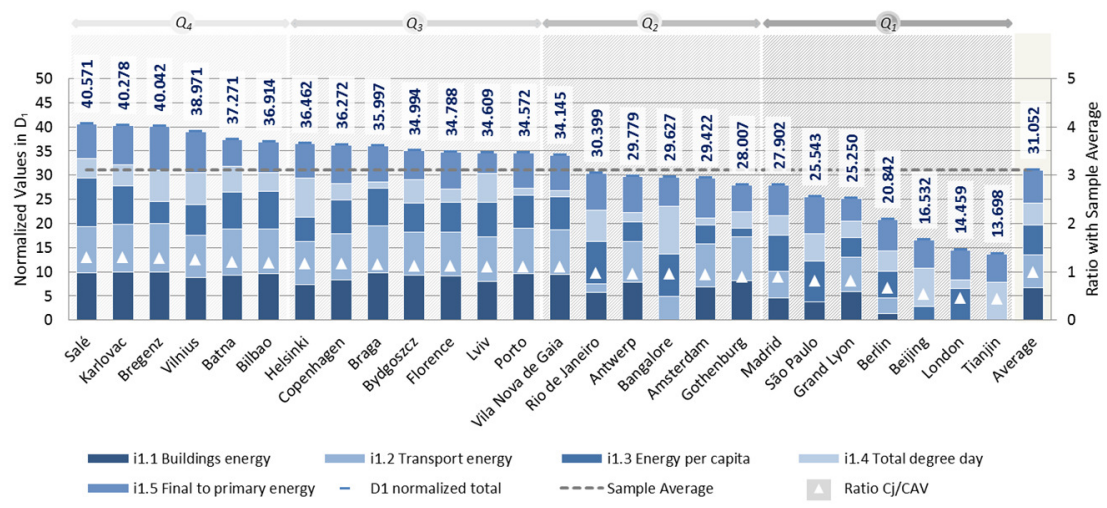

Figure 2. Normalized values of the indicators in $D_{1}$

\section{Results for penetration of energy and $\mathrm{CO}_{2}$ saving measures}

Figure 3 indicates that Copenhagen obtains a perfect score in $D_{2}$ based on a score of 50.000 for the sum of the normalized values of the indicators that evaluate the penetration of energy and $\mathrm{CO}_{2}$ saving measures. Such a performance represents the achievement of the top values in each indicator in this dimension. Other cities that take place in the top $25 \%$ at $Q_{4}$ include Berlin, London, and Grand Lyon that have normalized values between 46.667 and 44.667 while Helsinki, Amsterdam, and Gothenburg follow the performances of these cities based on the next best values above the top quartile threshold of 41.500. These cities in $Q_{4}$ adopt a more integrated approach towards optimizing the urban energy system from both the supply and demand sides. In contrast, the sample average $C_{A V}$ for $D_{2}$ is 30.327 with cities performing at ratios as low as 0.57 of this average value due to limitations in measures that encompass the urban energy supply structure and the demand side. From Sale (20.667) to Batna (18.667), the only strength is the monitoring of SEAP while the only relative strength of Bangalore (18.500) is the public transport network.

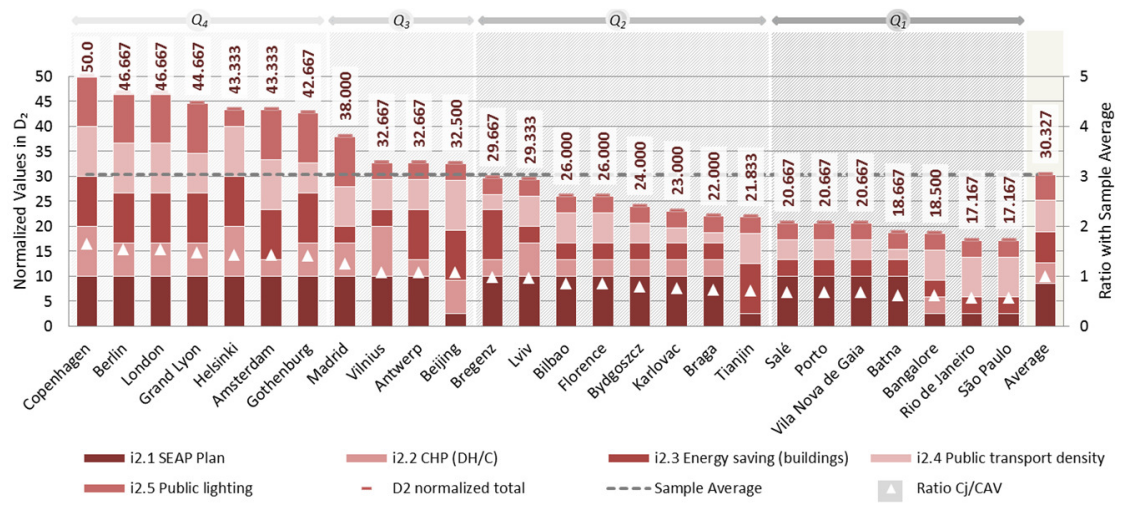

Figure 3. Normalized values of the indicators in $D_{2}$

\section{Results for renewable energy potential and utilization}

The results in Figure 4 indicate that Rio de Janeiro (34.494), São Paulo (32.799), and Gothenburg (29.294) attain the highest performances in $D_{3}$ among the 26 cities in the sample. The performances of these top performing cities have also increased from the previous reporting phases. For example, the renewable energy share in the electricity grid for Rio de Janeiro and São Paulo have increased by $9.9 \%$ in one year and reached $81.19 \%$ [156]. After these cities, the relatively high performance of Gothenburg is also supported by the second highest green energy share in transport including both biofuels and electricity at $14.34 \%$, which represents progress towards decarbonizing the transport sector. Based on aspects of both renewable energy potential and utilization, the average city receives a score of 22.403 in $D_{3}$ of which cities perform at ratios of 1.54 and 0.53 of this average value. 


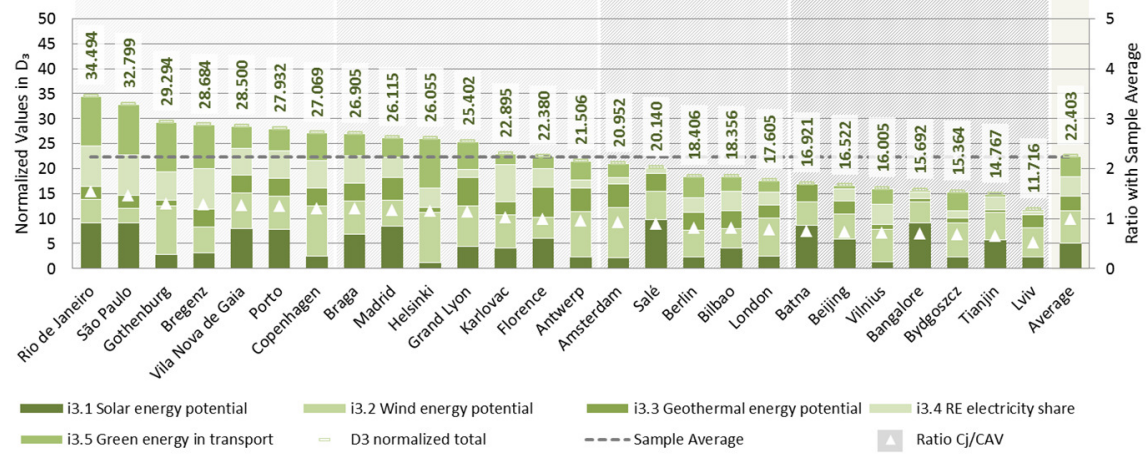

Figure 4. Normalized values of the indicators in $D_{3}$

\section{Results for water usage and environmental quality}

Figure 5 provides the normalized values of the indicators in $D_{4}$ in which the city of Helsinki (39.802) is found to be the top city in aspects of water usage and environmental quality. Helsinki is able to combine a relatively low footprint for blue water consumption with excellent water and air quality. In addition, the biocapacity per capita is much greater than the ecological footprint per capita, which places the city in a more favourable position considering the balance between the demand for land across various categories and the natural regenerative capacity. The cities of São Paulo (39.594) and Rio de Janeiro (37.420) surpass the performance of Helsinki in only one indicator, namely ecological footprint per capita, while the performance of Gothenburg (37.323) surpasses that of Helsinki in the indicator for the annual mean $\mathrm{PM}_{10}$ concentration. Other cities that take place in $Q_{4}$ are Vilnius (35.968), Braga (33.153), and Karlovac (32.624). In contrast, the average city in the sample receives a normalized value of 30.261 in $D_{4}$. Cities have performances at a ratio of at most 1.32 and at least 0.59 of this average value based on the triangular marks for each city.

The latter case of a 0.59 ratio with the average value represents Batna (17.890) that receives the lowest value in $D_{4}$ based on shortcomings in water quality, annual mean $\mathrm{PM}_{10}$ concentration, and biocapacity per capita. The cities of Tianjin (23.521) and Beijing (22.140) perform better than Batna only in the indicator for water quality with major shortcomings in annual mean $\mathrm{PM}_{10}$ concentration as well as biocapacity per capita. Here, only the ecological footprint per capita in Tianjin is lower than the value for Beijing [170].

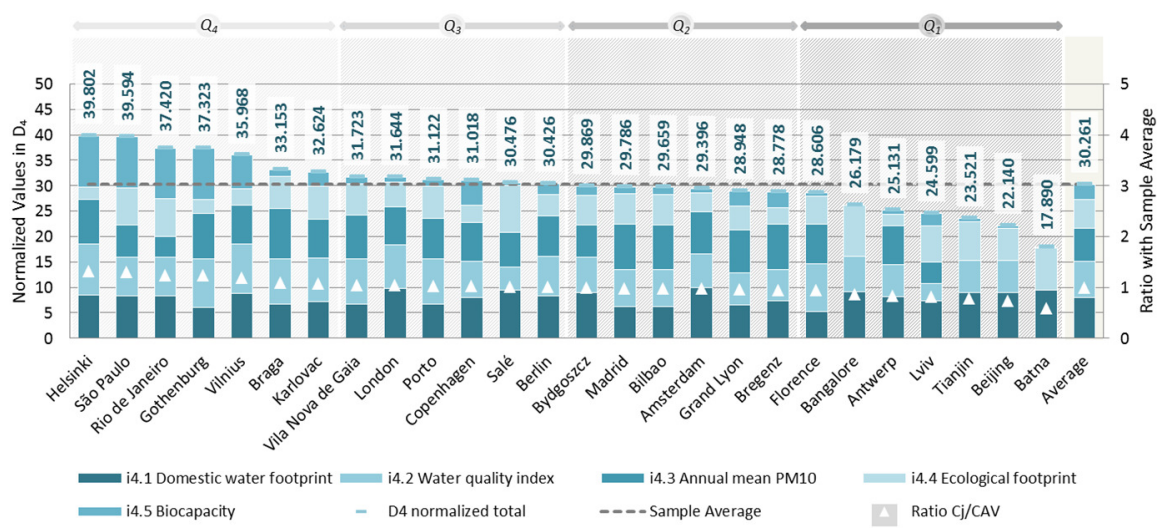

Figure 5. Normalized values of the indicators in $D_{4}$

\section{Results for $\mathrm{CO}_{2}$ emissions and industrial profile}

Figure 6 indicates that Bregenz (37.709) has the best performance in the indicators of $D_{5}$ for $\mathrm{CO}_{2}$ emissions and industrial profile. Copenhagen (37.620), Braga (37.346), and 
Vila Nova de Gaia (36.921) are the next best performing cities in $D_{5}$ with performances in $Q_{4}$. Three additional cities, namely, Karlovac (36.907), Helsinki (36.486), and Gothenburg (35.612) further take place in the top $25 \%$ of cities in $D_{5}$. In comparison to performances in previous dimensions, Bregenz and Karlovac had also taken in the top quartile in $D_{1}$ while Copenhagen, Helsinki, and Gothenburg had attained top performances in $D_{2}$. In addition, Bregenz, Copenhagen, Vila Nova de Gaia, and Gothenburg had obtained top places in $D_{3}$ for renewable energy and utilization. In contrast, the cities that are closest to the sample average for $D_{5}$, namely Bydgoszcz (27.548) and Lviv (27.207), have certain weaknesses, including those in $\mathrm{CO}_{2}$ emissions intensity of the energy mix. The cities that take place in the lowest $25 \%$ at $Q_{1}$ have values well below the bottom quartile threshold of 25.289 .

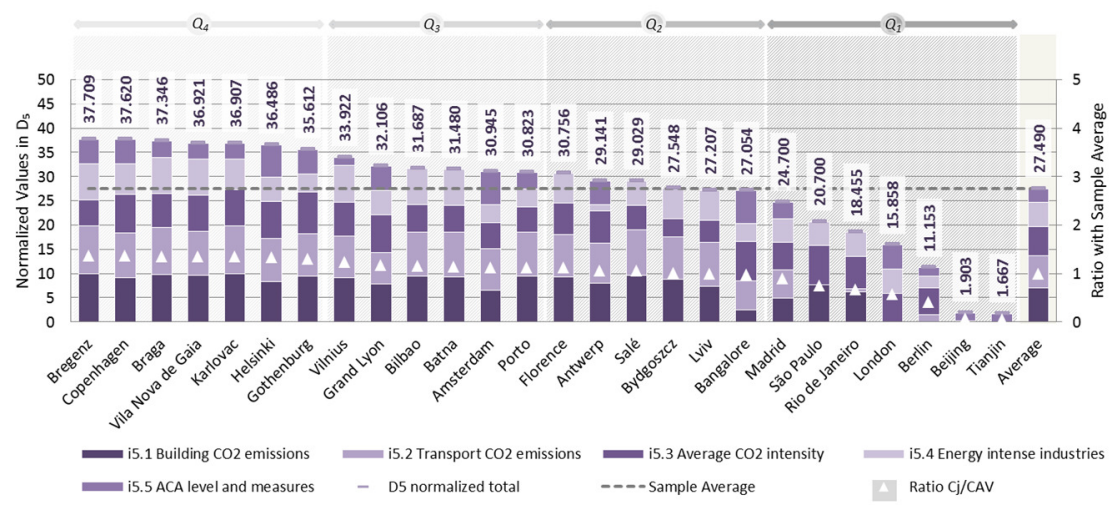

Figure 6. Normalized values of the indicators in $D_{5}$

\section{Results for urban planning and social welfare}

Based on the results in Figure 7, Gothenburg (39.107), Amsterdam (37.272), and Copenhagen (36.985) are the best performing cities in $D_{6}$ for urban planning and social welfare. These cities have advantages in multiple indicators under $D_{6}$, including those for waste and wastewater management, compact and green urban form, and inequality adjusted well-being. Best practices from Gothenburg include a recycling and composting share of $48.0 \%$, which is above the European average at $43.6 \%$ [204], and a negative sprawl index at $-1.97 \%$ that indicates a retracting urban area while $56.15 \%$ of the population is living in core urban areas [196]. In addition, Gothenburg has favourable performances in indicators for social welfare, including a tertiary education rate at $51.0 \%$ for the population aged 30-34. Other cities that take place in the top $25 \%$ of $D_{6}$ are London (35.874), Helsinki (35.265), Berlin (35.121), and Bregenz (34.289). The average city receives a score of 26.071 in $D_{6}$ with cities performing at a ratio of 1.50 above or 0.33 below this average value.

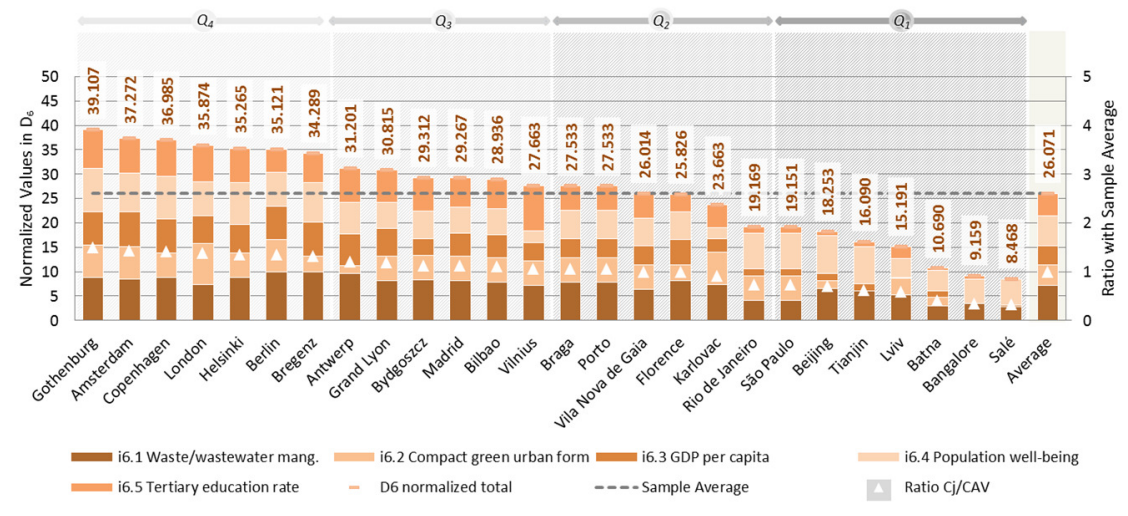

Figure 7. Normalized values of the indicators in $D_{6}$ 


\section{Results for $R \& D$, innovation and sustainability policy}

Figure 8 puts forth the results for the quartile performances of the cities in $D_{7}$ in which London (37.871), Berlin (37.754), and Copenhagen (31.460) are the top cities. Especially the top two cities obtain relatively strong performances in all of the five indicators. Among these cities, London has the strongest base of local public/private universities and research institutions, including those taking place in the SCImago top 1,000 institutions [224]. Such an outcome is rivalled only by the performances of Beijing and Tianjin that also take place in the top quartile for $D_{7}$. In addition to R\&D policy orientation, strengths of Copenhagen include its progress towards its climate neutrality target, particularly in the heating and cooling sector [231], with knowledge sharing with other cities. Following these cities, Amsterdam (30.281) and Helsinki (27.680) also take place in the top quartile.

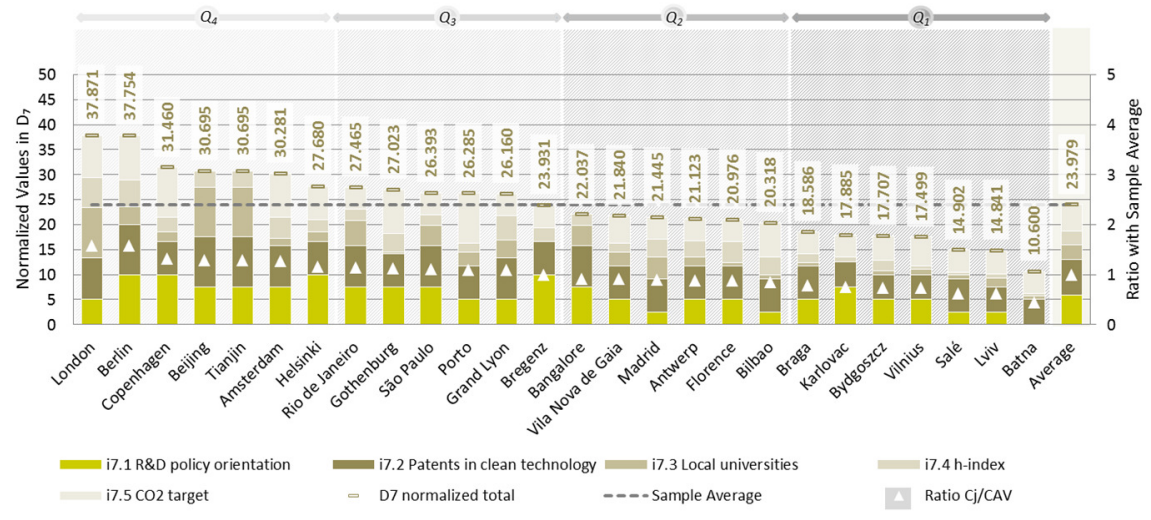

Figure 8 . Normalized values of the indicators in $D_{7}$

\section{Index results based on quartiles of city performance}

The normalized values that are provided in Figures 2-8 for each dimension of the SDEWES Index enable the aggregation of the values according to eq. (1) for each city in the sample. According to the method, the weights are also subjugated to 10,000 Monte Carlo experiments, the results for which are provided in Figure 9 based on an ordering with the original aggregated index value. In comparison to the mean simulated values of the Monte Carlo experiments, there is only one position in which an interchange of rank takes place between two adjacent cities in the sample. Antwerp advances while Madrid recedes by one rank each where higher ranks have decreasing rank number. The order of all other cities and the inclusion of cities in quartiles of performance are stable.

The colouring in Figure 9 is further representative of quartiles of city performance. The sample is normalized according to the overall integrated city sample [121] so that the number of cities that are allocated to each quartile may not be equal for the present city sample. Cities that take place in the lower $25 \%$ of the integrated sample $\left(Q_{1}\right)$ obtain an aggregated index score below 26.891, including the cities of Lviv and Berlin alongside 8 other cities. The cities in $Q_{1}$ have weaknesses in multiple dimensions and are termed as the "Challenged Cities" [56] of a given sample. The remaining cities that perform below or at the median value take place in the second quartile of $Q_{2}$, which includes Florence and Bilbao. These cities have a more limited set of weaknesses in any dimension and have been termed as the "Solution-Seeking Cities" [56]. Above the median value, the third quartile of $Q_{3}$ includes the cities of Porto and Karlovac for a total of 5 cities. These cities represent the "Transitioning Cities" [56] that are able to attain performances that are relatively better well-rounded across multiple dimensions. In contrast, the highest level of performance is reserved for cities in the top quartile $Q_{4}$ that are termed as the "Pioneering Cities" [56]. The 6 cities that take place with this status starting from the top performer are Copenhagen, Helsinki, Gothenburg, Bregenz, Amsterdam, and Vilnius. 


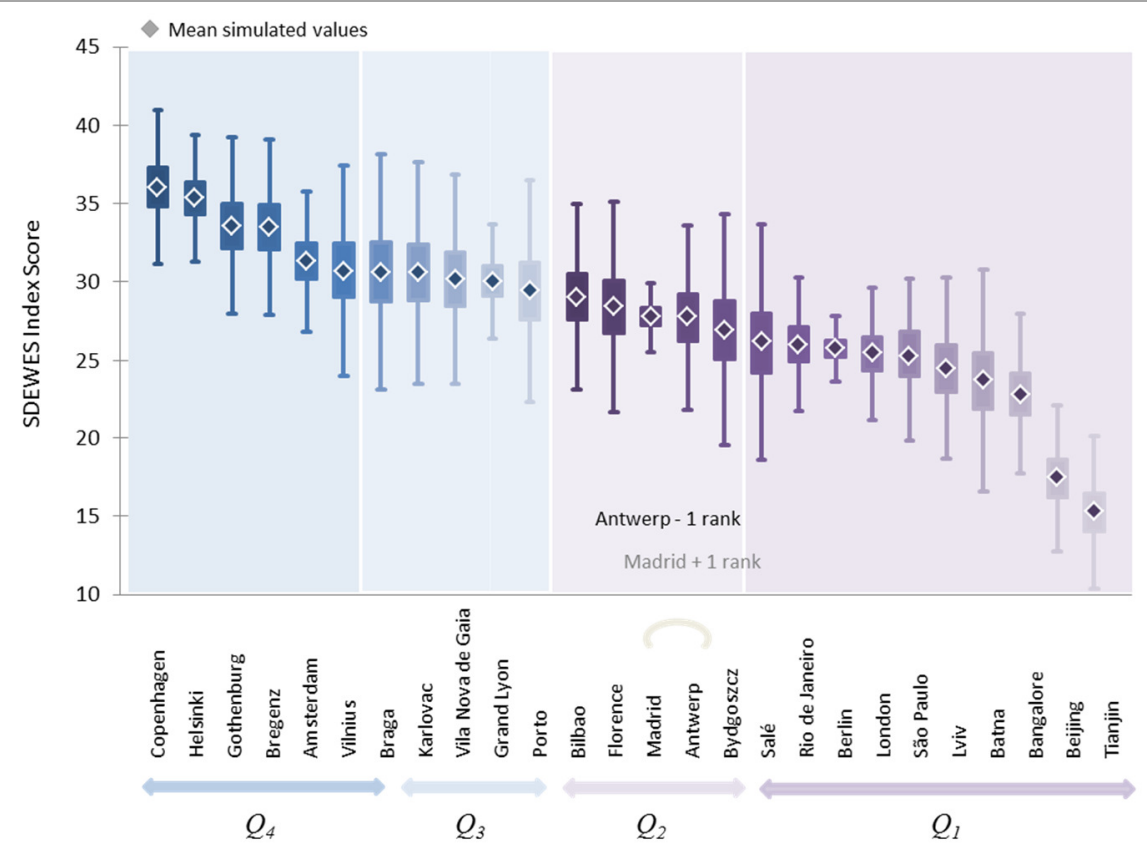

Figure 9. Results of the Monte Carlo simulations and performance quartiles

Table 10 summarizes the SDEWES Index scores for the 26 cities based on eq. (1). The percentage difference in the performance of each city with the median value of the integrated sample is also given. Copenhagen that ranks in first place with an index score of 36.038 performs $24.1 \%$ above the median value while Bilbao scores the closest to the median value with a difference of $-0.1 \%$ based on a value of 29.021 . Other cities perform well below the median value, including Lviv, Batna, Bangalore, Beijing and Tianjin.

Table 10. SDEWES Index results for the cities in the present sample

\begin{tabular}{cccccc}
\hline City & Index & $\% \Delta \mathrm{M}$ & City & Index & $\% \Delta \mathrm{M}$ \\
\hline Copenhagen & 36.038 & 24.1 & Madrid & 27.759 & -4.4 \\
Helsinki & 35.348 & 21.7 & Antwerp & 27.739 & -4.5 \\
Gothenburg & 33.572 & 15.6 & Bydgoszcz & 26.897 & -7.4 \\
Bregenz & 33.494 & 15.3 & Salé & 26.129 & -10.1 \\
Amsterdam & 31.311 & 7.8 & Rio de Janeiro & 25.981 & -10.6 \\
Vilnius & 30.704 & 5.7 & Berlin & 25.769 & -11.3 \\
Braga & 30.595 & 5.3 & London & 25.477 & -12.3 \\
Karlovac & 30.591 & 5.3 & São Paulo & 25.290 & -12.9 \\
Vila Nova de Gaia & 30.138 & 3.7 & Lviv & 24.470 & -15.8 \\
Grand Lyon & 30.030 & 3.4 & Batna & 23.722 & -18.3 \\
Porto & 29.422 & 1.3 & Bangalore & 22.839 & -21.4 \\
Bilbao & 29.021 & -0.1 & Beijing & 17.433 & -40.0 \\
Florence & 28.384 & -2.3 & Tianjin & 15.277 & -47.4 \\
\hline
\end{tabular}

Some of the best practices for the top three cities in the present sample are overviewed in Table 11. There is not a single best practice that can directly take a city to top ranks. Rather, one of the most important guiding principles to improve performances in the SDEWES Index is the implementation of an integrated approach across all dimensions simultaneously. The best practices that are selected for inclusion in Table 11 span urban energy, water and environment systems among other possible examples. The replication potential of the best practices can depend on multiple factors, such as local energy characteristics. However, the guiding approach that is put into action in the best practices, such as ensuring the more rational use of energy resources, protecting water resources, and minimizing waste and $\mathrm{CO}_{2}$ emissions, is directly applicable to all cities. 
Table 11. Exemplary best practices in energy, water and environment systems

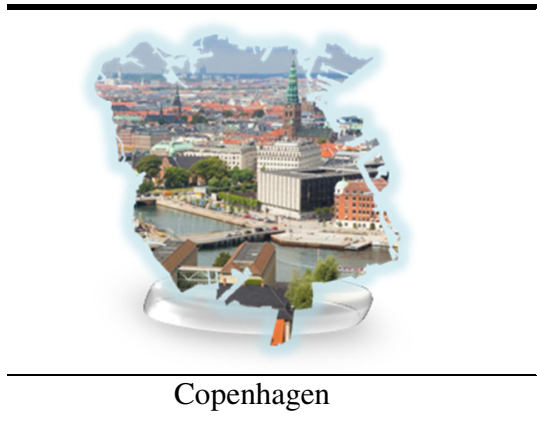

The city aims to be the first to reach climate neutrality in all sectors beyond only heating and cooling. The suburbs are being renovated for a low-temperature district heating network [134]

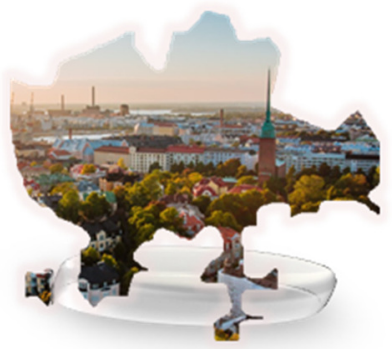

Helsinki
The city maintains high levels of water and environmental quality with an efficient urban energy system at 90\% efficiency in combined energy production with thermal energy
Gothenburg

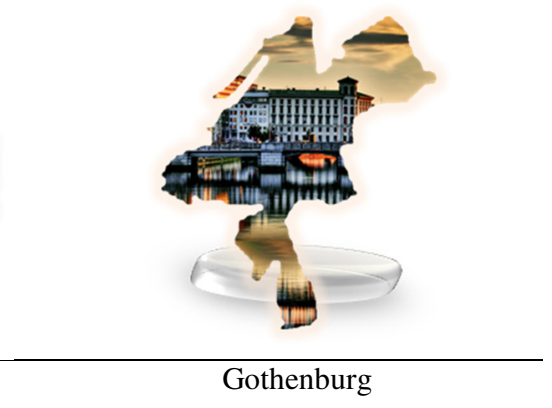

The city reversed urban sprawl and is seeking to be a more Water-Wise ${ }^{\mathrm{a}}$ city including a reduction of impermeable surfaces to improve water infiltration and green areas storage [232]

\section{Results of a normative scenario for Rio de Janeiro}

Based on the results in Figure 9 and Table 10, Rio de Janeiro takes place as one of the cities in the lower $25 \%$ quartile $\left(Q_{1}\right)$ among the "Challenged Cities." As one of the cities in this quartile, the city has weaknesses in certain dimensions. Based on data in Figures 2-8, the SDEWES Index results for Rio de Janeiro are compared in Figure 10 across all dimensions collectively. In comparison, the city performs close to the sample average in $D_{1}$, below the average in $D_{2}$, above the average in $D_{3}$ and $D_{4}$, below the average in $D_{5}$ and $D_{6}$, and above the average in $D_{7}$ to obtain a score of 25.981 as the overall Index value.

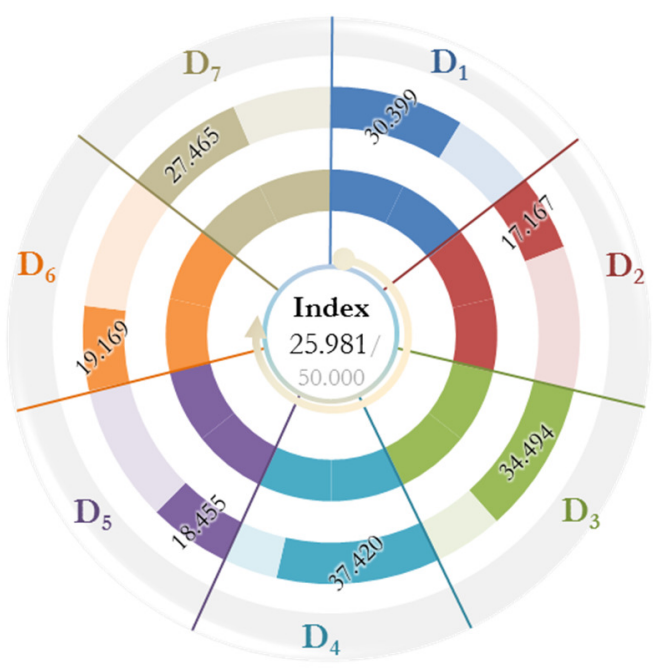

Figure 10. SDEWES Index results for the present performance of Rio de Janeiro

Any future developments in the city could enable increases in the performance of Rio de Janeiro. Table 12 summarizes local aspirations in the context of targets to realize Visão Rio 500 under the third theme of being "a green, sustainable, and resilient city" [124]. The first subtheme is sustainable development towards zero carbon [124]. The target years of related aspirations for this subtheme are provided along with connections to the scope of the SDEWES Index. Exemplary opportunities that are available to realize these aspirations and improve dimension and overall index scores of the city also take place within Table 12. Some of the principles are marked to have potential spill-overs to more than one dimension. 
Table 12. Ambitions in Visão Rio 500 and connections with the SDEWES Index (Part I)

\begin{tabular}{|c|c|c|c|}
\hline $\begin{array}{l}\text { Ambitions in } \\
\text { Visão Rio 500 }\end{array}$ & Principles $^{\mathrm{a}}$ & Target year ${ }^{\mathrm{a}}$ & $\begin{array}{l}\text { Dimension of SDEWES Index/ } \\
\text { Exemplary opportunities }\end{array}$ \\
\hline \multirow{3}{*}{$\begin{array}{l}\text { The City will obtain } \\
\text { an energy mix with } \\
\text { low carbon emissions }\end{array}$} & Efficiency in energy usage & 2035 & $\begin{array}{c}D_{1}, D_{2}: \text { Reduction in energy usage based } \\
\text { on replacement of individual cooling } \\
\text { units with district cooling } \\
\end{array}$ \\
\hline & $\begin{array}{l}60 \% \text { lower emissions from } \\
2012 \text { baseline emissions }\end{array}$ & 2050 & $\begin{array}{l}D_{3}, D_{5} \text { : Cross-sector approaches in } \\
\text { the energy, water and environment } \\
\text { sectors, i.e. demand management in } \\
\text { the wastewater treatment plant }\end{array}$ \\
\hline & $\begin{array}{c}\text { Zero fossil fuel usage/ } \\
\text { Carbon neutrality }\end{array}$ & $2065^{\mathrm{b}}$ & $\begin{array}{l}D_{5}: \text { Electrification of transport and } \\
\text { increase in the use of light urban rail }\end{array}$ \\
\hline \multirow[b]{2}{*}{$\begin{array}{l}\text { All new buildings will } \\
\text { be eco-efficient and } \\
\text { there will be incentives } \\
\text { for modernization of the } \\
\text { existing building stock }\end{array}$} & $\begin{array}{l}\text { All municipal buildings will } \\
\text { be modern and sustainable }\end{array}$ & 2050 & $\begin{array}{c}D_{1}, D_{2}, D_{3}, D_{4}, D_{5}: \text { Utilization of } \\
\text { solar energy in buildings with lower } \\
\text { energy demand, possibly net-zero } \\
\text { buildings, and water use reduction }\end{array}$ \\
\hline & $\begin{array}{l}30 \% \text { lower emissions } \\
\text { from building construction }\end{array}$ & 2050 & $\begin{array}{c}D_{6}: \text { Possible recovery of materials from } \\
\text { wastewater sludge for building } \\
\text { construction (concrete filler and } \\
\text { aggregate material/binder [233-234]) } \\
D_{7} \text { : Enabled with R\&D and innovation } \\
\text { activities, including on life cycle } \\
\text { assessment and material recovery }\end{array}$ \\
\hline \multirow{2}{*}{$\begin{array}{l}\text { All household waste } \\
\text { will be focused on } \\
\text { reducing, reusing, } \\
\text { transforming and } \\
\text { generating energy }\end{array}$} & $50 \%$ less waste generation & 2050 & $\begin{array}{c}D_{4}, D_{5}, D_{6} \text { : Awareness to prevent excess } \\
\text { organic and inorganic waste generation } \\
\text { to reduce ecological footprint and lower } \\
\text { city emissions }\end{array}$ \\
\hline & Zero landfill of waste & 2065 & $\begin{array}{c}D_{4}, D_{5}, D_{6} \text { : Circular economy to valorize } \\
\text { waste based on resource recovery } \\
\text { (chemical and materials) } \\
\end{array}$ \\
\hline $\begin{array}{l}\text { The City has sustainable } \\
\text { mobility supported by } \\
\text { clean technologies and } \\
\text { intelligent urban planning }\end{array}$ & $\begin{array}{l}\text { All means of transport } \\
\text { will be carbon neutral }\end{array}$ & 2065 & $\begin{array}{c}D_{1}, D_{2}, D_{3}, D_{4}, D_{5}: \text { More efficient } \\
\text { transport, including public, shared and } \\
\text { distributed means (bicycle sharing) using } \\
\text { low carbon energy } \\
D_{6} \text { : Integration with transit-oriented } \\
\text { development and compact cities }\end{array}$ \\
\hline
\end{tabular}

Already, the City Hall has issued the Qualiverde label that provides financial incentives to buildings with reduced environmental impact [235]. The use of solar panels, green roofs, and efficient lighting is indicated to be increasing [235]. In the aspect of urban transport, new Bus Rapid Transit lines and a light rail transport in Porto Maravilha are transforming mobility options with benefits for energy, emissions, time, and social cohesion. In addition, $400 \mathrm{~km}$ of bicycle paths represent the greatest extent in Latin America [124]. Under waste management, however, 3\% of total waste generation is recycled whereas the recyclable fraction is about $40 \%$ [124] that requires greater separate collection. In the meantime, a new waste treatment center (Seropédica) has been opened that involves bioenergy production while the old landfill at Gramacho is installed with a landfill gas recovery system [124].

The exemplary opportunities in Table 12 further extend to the use of wastewater sludge to recover nutrients and materials, including those that could be recovered to produce concrete fillers and aggregate binders as building construction material [233-234]. The replacement of individual cooling units in buildings with district cooling is another solution. Best practices of better performing cities can be adapted to the context of Rio de Janeiro. 
Under Visão Rio 500, the second subtheme towards "a green, sustainable, and resilient city" involves resilience to climate change for minimizing damage and saving lives [124]. The ambitions of this subtheme are summarized in Table 13 along with the principles and target years. The rivers of the city can supply up to 9 thousand tons of water per day for treatment as tap water in regular seasons [124]. In contrast, the rivers can also pose treats to urban inundation. Currently, flood control measures are implemented throughout the city, including in Grande Tijuca and Praça da Bandeira while the Jacarepaguá Basin is reinforced with a macro-drainage system [124]. The limitation of urban sprawl to avoid development into areas that may be prone to risks of landslides and floods is also another valid option based on the indicator on compact and green urban form in $D_{6}$ of the SDEWES Index.

Table 13. Ambitions in Visão Rio 500 and connections with the SDEWES Index (Part II)

\begin{tabular}{|c|c|c|c|}
\hline $\begin{array}{c}\text { Ambitions in } \\
\text { Visão Rio 500 }\end{array}$ & Principles $^{\mathrm{a}}$ & Target year ${ }^{\mathrm{a}}$ & $\begin{array}{l}\text { Dimension of SDEWES Index/ } \\
\text { Exemplary opportunities }\end{array}$ \\
\hline $\begin{array}{l}\text { No family will live } \\
\text { in a situation of high } \\
\text { physical vulnerability }\end{array}$ & $\begin{array}{l}\text { No residence will be at risk } \\
\text { of landslides and floods }\end{array}$ & 2035 & $\begin{array}{l}D_{6}: \text { Urban planning for compact and } \\
\text { green urban form, limiting of urban } \\
\text { sprawl to avoid prone land areas }\end{array}$ \\
\hline \multirow{2}{*}{$\begin{array}{l}\text { The City will be prepared } \\
\text { and adapted } \\
\text { to climate change } \\
\text { and its effects }\end{array}$} & $\begin{array}{l}\text { There will be } 50 \% \text { less } \\
\text { annual average economic } \\
\text { losses resulting from } \\
\text { climatic events }\end{array}$ & 2050 & $\begin{array}{c}D_{6}: \text { Related actions involve benefits for } \\
\text { social welfare and satisfaction }\end{array}$ \\
\hline & $\begin{array}{l}\text { The surface of the hottest } \\
\text { neighborhoods will be } 3 \\
\text { degrees lower on average }\end{array}$ & 2050 & $\begin{array}{l}D_{6}: \text { Urban planning to increase green } \\
\text { areas to limit urban heat islands }\end{array}$ \\
\hline $\begin{array}{l}\text { All citizens will be } \\
\text { informed, prepared and } \\
\text { engaged to respond to the } \\
\text { impacts of the changing } \\
\text { weather }\end{array}$ & $\begin{array}{l}\text { Volunteerism and } \\
\text { mobilizing capacity } \\
\text { will be } 25 \% \text { higher }\end{array}$ & 2035 & $\begin{array}{c}D_{6}: \text { Related actions involve benefits for } \\
\text { social welfare and satisfaction }\end{array}$ \\
\hline
\end{tabular}

The third subtheme through which Rio de Janeiro seeks to be a global benchmark as "a green, sustainable, and resilient city" is based on protecting its water resources in the form of beaches, bays, ponds and rivers [124]. As an extended interpretation of the name of the city, Rio de Janeiro aims to become a "City of Waters" while upholding the highest standards for water quality and water sanitation. Table 14 provides the ambitions of the city under this subtheme together with the principles and target years. The ambitions as given in Table 14 are important given that some of the water bodies of the city, including the Bay of Guanabara and the lagoon of Barra, are poorly used due to frequent pollution issues [124].

Rio de Janeiro is recognized as a city with insufficient infrastructure for water treatment based on low coverage of wastewater collection and missing connections [124]. The share of wastewater treated to total water consumed had been about 50\% [236] while a new wastewater treatment plant is operational [237]. An interim target is set towards ensuring $80 \%$ coverage of wastewater treatment to overcome current insufficiencies in providing for basic sanitary needs [124]. Water stress is another area of concern such that periods of drought can impact the limited water supplies from the reserve of the Guandu and Paraíba do Sul River [124]. As a remedy to these concerns, alternative sources of water supplies are expected to be tapped. At the same time, access to water supplies that may be further away from the city may increase energy needs for the transport of water. The use of gravity distribution networks may be maximized and electricity for water pumping can be met with the co-location of renewable energy in water facilities among possible options (Table 14). 
Table 14. Ambitions in Visão Rio 500 and connections with the SDEWES Index (Part III)

\begin{tabular}{|c|c|c|c|}
\hline $\begin{array}{l}\text { Ambitions in } \\
\text { Visão Rio } 500^{\mathrm{a}}\end{array}$ & Principle $^{\mathrm{a}}$ & $\begin{array}{l}\text { Target } \\
\text { year }^{\mathrm{a}}\end{array}$ & $\begin{array}{l}\text { Dimension of SDEWES Index/ } \\
\text { Exemplary opportunities }\end{array}$ \\
\hline \multirow{3}{*}{$\begin{array}{l}\text { Rio will have a } \\
\text { secure water supply } \\
\text { by mapping risks } \\
\text { and tracing coping } \\
\text { strategies }\end{array}$} & $\begin{array}{c}\text { Losses in water } \\
\text { distribution are reduced } \\
\text { by } 80 \%\end{array}$ & 2035 & $\begin{array}{c}D_{2}, D_{4}, D_{5} \text { : Less energy requirements } \\
\text { for pumping in the water } \\
\text { distribution network, less } \\
\text { emissions and reduced domestic } \\
\text { blue water footprint }\end{array}$ \\
\hline & $\begin{array}{c}\text { The water quality of all } \\
\text { surface water sources } \\
\text { and underground areas } \\
\text { of the City will be } \\
\text { guaranteed }\end{array}$ & 2050 & $\begin{array}{l}D_{4} \text { : Improvements in the water } \\
\text { quality index based on dissolved } \\
\text { oxygen, pH level, conductivity, } \mathrm{N} \\
\text { and P elements }\end{array}$ \\
\hline & $\begin{array}{l}20 \% \text { of the city's supply } \\
\text { capacity will be an } \\
\text { alternative source to the } \\
\text { Guandu Basin }\end{array}$ & 2065 & $\begin{array}{c}D_{3}: \text { Use of gravity distribution } \\
\text { networks and co-location of } \\
\text { renewable energy in water } \\
\text { facilities }\end{array}$ \\
\hline \multirow{3}{*}{$\begin{array}{l}\text { Rio will be a hub } \\
\text { for universal basic } \\
\text { sanitation in the } \\
\text { metropolitan area, } \\
\text { clearing the water } \\
\text { bodies of the region }\end{array}$} & $\begin{array}{l}\text { The whole city will have } \\
\text { access to basic sanitation }\end{array}$ & 2035 & $\begin{array}{c}D_{6}: \text { Comprehensive collection of } \\
\text { wastewater and compliance with } \\
\text { wastewater treatment standards }\end{array}$ \\
\hline & $\begin{array}{l}\text { Guanabara and Sepetiba } \\
\text { bays will be within the } \\
\text { international standards } \\
\text { of water quality }\end{array}$ & 2035 & $\begin{array}{l}D_{4} \text { : Improvements in the water } \\
\text { quality index based on dissolved } \\
\text { oxygen, } \mathrm{pH} \text { level, conductivity, } \mathrm{N} \\
\text { and } \mathrm{P} \text { elements }\end{array}$ \\
\hline & $\begin{array}{l}\text { All beaches in the city } \\
\text { will be swimmable } \\
\text { beaches }\end{array}$ & 2050 & $\begin{array}{l}D_{4} \text { : Improvement in surface water } \\
\text { quality, including bathing waters }\end{array}$ \\
\hline $\begin{array}{l}\text { The economic and } \\
\text { leisure potential of } \\
\text { rivers, lakes and the } \\
\text { ocean will be harnessed } \\
\text { for Carioca livelihoods }\end{array}$ & $\begin{array}{l}\text { Economic participation of } \\
\text { the coastal zone in the } \\
\text { city will have tripled }\end{array}$ & 2050 & $\begin{array}{c}D_{4}, D_{6} \text { : Clean waters can better } \\
\text { support social welfare and } \\
\text { better integrate green-blue } \\
\text { landscapes in urban form }\end{array}$ \\
\hline $\begin{array}{l}\text { The population will not } \\
\text { waste water and reuse } \\
\text { will be part of the City }\end{array}$ & $\begin{array}{l}\text { Per capita water usage } \\
\text { will be } 50 \% \text { lower }\end{array}$ & 2050 & $\begin{array}{l}D_{2}, D_{4}, D_{5}: \text { Reduction in the } \\
\text { domestic blue water footprint with } \\
\text { less energy requirements in the } \\
\text { water sector }\end{array}$ \\
\hline
\end{tabular}

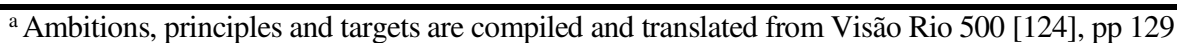

The ambitions, principles and target years as summarized in Tables 12-14 are used to consider a Visão Rio 500 scenario for Rio de Janeiro under the SDEWES Index. Only those indicators that are directly impacted by the targets as defined in Tables 12-14 are changed according to Visão Rio 500. Those that are used in the Average City to catch the best performing cities by target years as given in [121] are used for the other indicators.

Targets that required an update based on Visão Rio 500 include $60 \%$ lower emissions from 2012 baseline emissions by the year 2050 (see Table 12). The realization of this target requires an annual average reduction of about $1.58 \%$ each year based on eq. (3), which is lower than those for an Average City scenario [121]. In practical terms, reductions in $\mathrm{CO}_{2}$ emissions involve the effect of both efficiency and renewable energy measures. For this reason, $\mathrm{CO}_{2}$ emission reductions based on the Visão Rio 500 target need to be decomposed. Only expected contributions from any efficiency measures are represented in the scenario values of indicators on urban energy usage that is represented in dimension $D_{1}$. The possible share of $\mathrm{CO}_{2}$ emission reductions based on efficiency measures in total $\mathrm{CO}_{2}$ emission reductions is adapted from International Energy Agency projections [4] (see Table 15). 
Table 15. Expected contribution shares of measures in total $\mathrm{CO}_{2}$ emission reductions

\begin{tabular}{ccccccccc}
\hline Measure & 2016 & 2020 & 2025 & 2030 & 2035 & 2040 & 2045 & 2050 \\
\hline $\mathrm{EE}^{\mathrm{a}, \mathrm{c}}$ & $62 \%$ & $53 \%$ & $49 \%$ & $44 \%$ & $41 \%$ & $38 \%$ & $37 \%$ & $37 \%$ \\
$\mathrm{RE}^{\mathrm{b}, \mathrm{c}}$ & $38 \%$ & $47 \%$ & $51 \%$ & $56 \%$ & $59 \%$ & $62 \%$ & $63 \%$ & $63 \%$ \\
& & &
\end{tabular}

In comparison to the recent analysis provided by the $\mathrm{C} 40$ network in [5], however, a target year of 2065 for carbon neutrality would not be compatible with the remaining $\mathrm{CO}_{2}$ budget that can provide a fair chance of limiting global warming to at most $1.5^{\circ} \mathrm{C}$ by the end of century. Since the adoption of Visão Rio 500, the city of Rio de Janeiro was announced as one of the C40 cities to adopt a carbon neutrality target by the year 2050 [125], which can modify the original target for reaching carbon neutrality given a stability of political will.

In aspects of urban water and waste issues, the target of enabling a reduction in per capita water usage by $50 \%$ by the year 2050 (see Table 14) was integrated into scenario values based on reductions at about $0.097 \mathrm{~m}^{3}$ per year based on eq. (3). The target of guaranteeing the water quality of all surface water sources by the year 2050 (see Table 14) required an extension of the related target so that Rio de Janeiro attained the level of the best performing city by the same target year based on eq. (2). The generation of $50 \%$ less waste by the year 2050 (see Table 12) was taken to involve reductions of about $1.42 \%$ each year from existing levels based on eq. (3). Two of the Visão Rio 500 targets, namely the provision of basic sanitation infrastructure for the entire city and ensuring that no residence will be at risk of landslides and floods (see Tables 13-14) have the same target year at 2035. This implied an extended target of Rio de Janeiro reaching the values of the best performing city for the related indicators in $D_{6}$ involving wastewater management and urban form.

In contrast to the overall performance of Rio de Janeiro as given above in Figure 10, the performance in Figure 11 compares the results of the city under a normative scenario for the year 2050 based on targets in the local plan of Visão Rio 500 and the C40 carbon neutrality target. As indicated previously, the target values of the best performing city in the integrated sample are taken for all other indicators [121]. Based on the normative scenario, the index score of Rio de Janeiro at 44.762 in the year 2050 would surpass the score of the currently top performing city under dynamic conditions for the scenario and static conditions for the other cities. In reality, however, dynamic conditions apply to all cities equally and relative performance will continue to change the values of the best performing city in the sample across time. The evaluation of the present performance and future opportunities are discussed in Table 16.

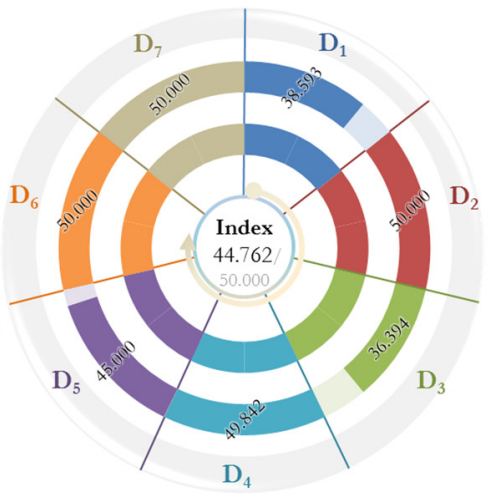

Figure 11. SDEWES Index results for a normative scenario for Rio de Janeiro 
Table 16. Summary of the present and scenario performance of Rio de Janeiro

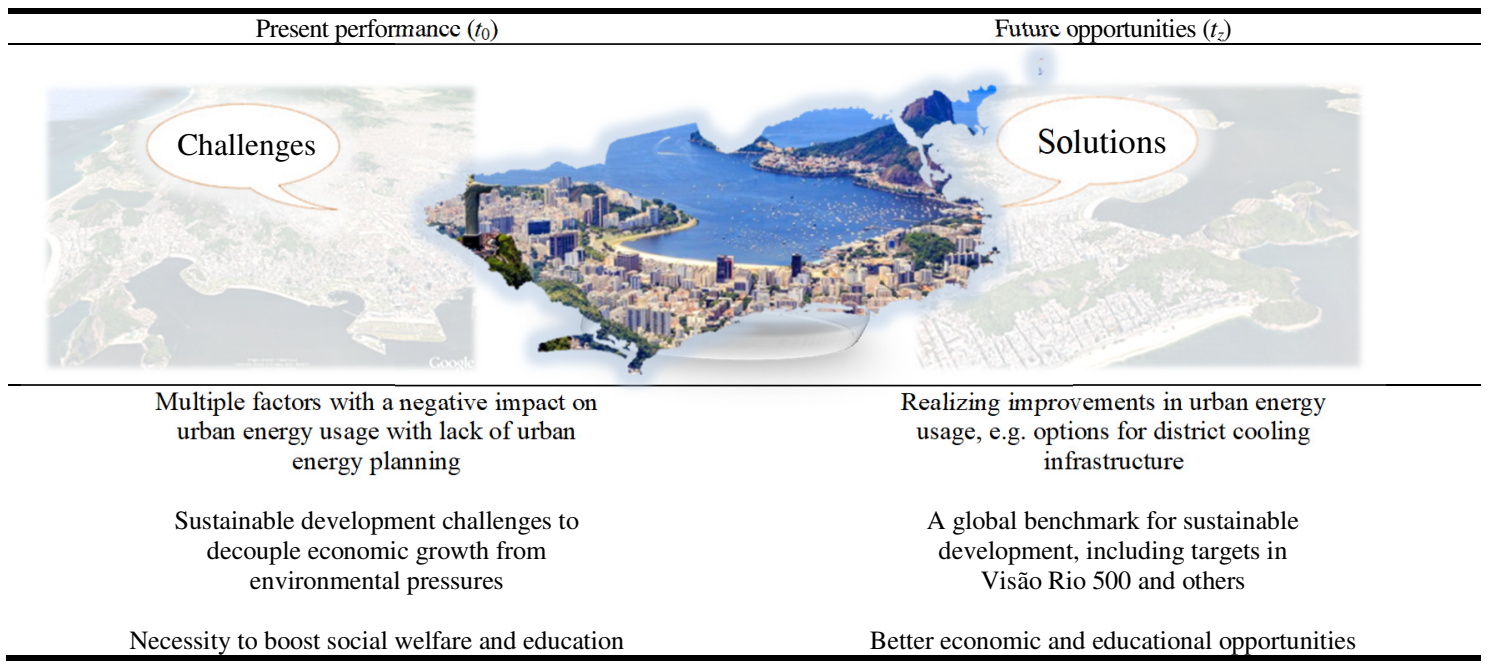

\section{CONCLUSIONS}

Ever since the Earth Summit in Rio de Janeiro, the necessity for urban sustainability has been a prominent challenge in the global agenda waiting to be addressed. The complexity of the challenge similarly extends to the task of measuring and comparing the sustainability of cities. In previous phases of the research work, the SDEWES Index was developed as an original indicator to benchmark cities with a focus on urban energy, water and environment systems [53-56]. The SDEWES Index can provide a useful benchmarking tool to compare the performance of cities based on a relative framework for assessing sustainability.

The present research work applied the SDEWES Index to a fifth sample that included 26 cities from around the world. Such a new sample advanced the geographical diversity of previous samples with the inclusion of cities from Latin America and Africa as well as new cities from Asia. The diversity of the sample holds importance during a time in which the CoM has launched a global initiative and C40 announced carbon neutrality targets at COP23 [125]. The results indicate that Copenhagen is the benchmark leader of the sample based on the first place rank in the top 25\% quartile of performance. The SDEWES Index score of Copenhagen is 36.038 , which is $24.1 \%$ above the median value of the integrated sample. Such a performance is attributed to a well-rounded level of performance across the index with consistently above average performance in all dimensions. This attribute allows Copenhagen to take place as the leader of the "Pioneering Cities" quartile of the sample. Some of the most essential best practices of the cities in the top quartile include efficient district energy networks and effective urban management in water and environment aspects.

Rio de Janeiro currently takes place as one of the "Challenged Cities" of the sample to which a normative scenario is envisioned to boost the city's performances in the future. The normative scenario underlined the way in which the pursuit of local targets in the Visão Rio 500 plan and the C40 target for carbon neutrality can advance the city as the envisioned global benchmark. In addition to emphasizing the success of benchmark leaders, the focus on Rio de Janeiro contributed to assessing the challenges and opportunities in cities that are not performing at the top levels. More inclusively, the application of the normative scenario exemplified the necessity for Rio de Janeiro to make improvements within the SDEWES Index by overcoming multiple sustainable development difficulties to decouple economic growth from environmental pressures. According to the results of the normative scenario, a value of 44.762 could be possible under static conditions for all other cities. However, challenges remain since all cities will undertake improvements in a dynamic context. It is envisioned that cities around the 
world will continue to benefit from the benchmarking results of the SDEWES Index to transform weaknesses into relative strengths, especially in a crucial time when nothing less than making rapid progress towards carbon neutrality targets is urgently needed.

\section{ACKNOWLEDGEMENT}

The research work is based on original scientific contributions that were presented at the SDEWES Conference series, particularly the $11^{\text {th }}$ SDEWES Conference in Lisbon, Portugal during September 4-9, 2016 and the $1^{\text {st }}$ Latin American Conference in Rio de Janeiro, Brazil during January 28-31, 2018. The author kindly acknowledges the opportunity of organizing a Special Session in the scientific programme at Rio de Janeiro to focus on urban challenges in Latin American cities and beyond for the exchange of scientific knowledge and solutions.

\section{NOMENCLATURE}

$C$
$C^{\prime}$
$D$
$D_{1}$
$D_{2}$
$D_{3}$
$D_{4}$
$D_{5}$
$D_{6}$
$D_{7}$
$i$
$I$
$t$
$Q$
$z$

\section{Greek letters}

$\alpha$

Subscripts
$t_{0}$
$A V$
$j$
$t_{s}$
$t_{(z)}$
$T$
$x$
$y$

\section{Abbreviations}

4GDH

ACA

BOD

C40

CDD

CHP

COD

$\mathrm{CoM}$

COP23

$\mathrm{COP}$ specific city in the sample

scenario version of a specific city

dimensions of the SDEWES Index $\left(D_{1}-D_{7}\right)$

energy usage and climate dimension

penetration of energy and $\mathrm{CO}_{2}$ saving measures dimension

renewable energy potential and utilization dimension

water usage and environmental quality dimension

$\mathrm{CO}_{2}$ emissions and industrial profile dimension

urban planning and social welfare dimension

$R \& D$, innovation and sustainability policy dimension

data inputs into the indicators of the SDEWES Index

normalized values of the indicators in the SDEWES Index

time variables in the normative scenario [eqs. (2-3)]

quartile of performance in the dimensions or overall index

number of calendar years between $t_{0}$ and $t_{(z)}$

weights of the dimensions of the SDEWES Index [eq. (1)]

time of present performance

present sample average (used in Figures 2-8)

number of the city in the sample

target time to realize a specific value

future time in a normative scenario

condition where $j=T$ for target city value

dimension number in the index

indicator number in the dimension

Fourth Generation District Heating

Airport Carbon Accreditation

Biochemical Oxygen Demand

Cities Climate Leadership Group

Cooling Degree Day

Combined Heat and Power

Chemical Oxygen Demand

Covenant of Mayors

$23^{\text {rd }}$ Session of the Conference of Parties

Coefficient of Performance 


\begin{tabular}{ll}
\hline DH/C & District Heating and/or Cooling \\
EE & Energy Efficiency \\
ETS & Emissions Trading System \\
GDP & Gross Domestic Product \\
GERD & Gross Domestic Expenditure on R\&D \\
HDD & Heating Degree Day \\
HOB & Heat Only Boilers \\
IEA & International Energy Agency \\
IRENA & International Renewable Energy Agency \\
nZEB & Nearly Net-Zero Energy Buildings \\
PETA & Pan-European Thermal Atlas \\
PM 10 & Particulate Matter up to 10 micrometers in diameter \\
PV & Photovoltaic \\
PV-T & Photovoltaic-Thermal \\
R\&D & Research and Development \\
RE & Renewable Energy \\
SDEWES & Sustainable Development of Energy, Water and Environment Systems \\
SEAP & Sustainable Energy Action Plan(s) \\
SECAP & Sustainable Energy and Climate Action Plan(s) \\
SEE & South East Europe \\
TES & Thermal Energy Storage \\
TSS & Total Dissolved Solids \\
UNFCCC & United Nations Convention on Climate Change
\end{tabular}

\section{REFERENCES}

1. World Commission on Environment and Development, Our Common Future, Oxford: Oxford University Press, Oxford, UK, 1987.

2. United Nations Division for Sustainable Development, Agenda 21, United Nations Conference on Environment \& Development, Rio de Janerio, Brazil, 1992.

3. UNFCCC, First Steps to a Safer Future: United Nations Framework Convention on Climate Change,

2014 , http://unfccc.int/essential_background/convention/items/6036.php, [Accessed: 25-February-2018]

4. IEA, Energy Technology Perspectives 2016 - Towards Sustainable Urban Energy Systems, Executive Summary, Paris, France, 2016.

5. C40 Cities - Arup, Deadline 2020: How Cities will get the Job done, London, UK, 2017.

6. United Nations General Assembly Resolution 66/288, The Future We Want, A/RES/66/288, 2012, http://undocs.org/A/RES/66/288, [Accessed: 25-February-2018]

7. UN, Sustainable Development Goals: 17 Goals to transform our World, http://www.un.org/sustainabledevelopment/sustainable-development-goals/, [Accessed: 25-February-2018]

8. Pincetl, S., Cities in the Age of the Anthropocene: Climate Change Agents and the Potential for Mitigation, Anthropocene, Vol. 20, pp 74-82, 2017, https://doi.org/10.1016/j.ancene.2017.08.001

9. Intergovernmental Panel on Climate Change, Cities and Climate Change Science Conference, https://www.ipcc.ch/meetings/cities/, [Accessed: 25-February-2018]

10. United Nations Department of Economic and Social Affairs Population Division, 2014 Revision of the World Urbanization Prospects, ST/ESA/SER.A/366, New York, USA, 2015.

11. Covenant of Mayors for Climate and Energy, http://www.covenantofmayors.eu/, [Accessed: 25-February-2018]

12. Cities Climate Leadership Group, The Power of C40 Cities, http://www.c40.org/cities, [Accessed: 25-February-2018] 
13. Global Covenant of Mayors for Climate and Energy, http://www.globalcovenantofmayors.org/cities/, [Accessed: 25-February-2018]

14. European Commission, EU Covenant of Mayors and Compact of Mayors launch largest Global Coalition of Cities committed to fighting climate change, 2016, Brussels, Belgium.

15. Rogelj, J., Luderer, G., Pietzcker, R., Kriegler, E., Schaeffer, M., Krey, V. and Riahi, K., Energy System transformations for limiting end of-century warming to below $1.5{ }^{\circ} \mathrm{C}$, Nature Climate Change, Vol. 5, pp 519-27, 2015, https://doi.org/10.1038/nclimate2572

16. EU Covenant of Mayors Office, The Covenant of Mayors for Climate \& Energy in Europe: Key Figures, 2017.

17. Kona A., Melica G., Bertoldi P., Rivas Calvete S., Koffi B., Iancu, A., Zancanella P., Janssens-Maenhout, G. and Dallemand, J. F., Covenant of Mayors in Figures: 8-year assessment, EUR 28723 EN, Publications Office of the European Union, Luxembourg, Luxembourg, 2017.

18. Schroeder, P. and Chapman, R., Renewable Energy Leapfrogging in China's Urban Development? Current Status and Outlook, Sustainable Cities and Society, Vol. 11, pp 31-39, 2014, https://doi.org/10.1016/j.scs.2013.11.007

19. Ramos, A., Chatzopoulou, M., Guarracino, I., Freeman, J. and Markides, C., Hybrid Photovoltaic-thermal solar systems for combined heating, cooling and power provision in the Urban Environment, Energy Conversion and Management, Vol. 150, pp 838-850, 2017, https://doi.org/10.1016/j.enconman.2017.03.024

20. Nastasi, B. and Lo Basso, G., Power-to-Gas integration in the transition towards future Urban Energy Systems, International Journal of Hydrogen Energy, Vol. 42, No. 38, pp 23933-23951, 2017, https://doi.org/10.1016/j.ijhydene.2017.07.149

21. Unternährer, J., Moret, S., Joost, S. and Maréchal, F., Spatial clustering for District Heating integration in urban energy systems: Application to geothermal energy, Applied Energy, Vol. 190, pp 749-763, 2017, https://doi.org/10.1016/j.apenergy.2016.12.136

22. An, Q., Wang, Y., Zhao, J., Luo, C. and Wang, Y., Direct utilization Status and Power generation potential of low-medium Temperature Hydrothermal Geothermal Resources in Tianjin, China: A Review, Geothermics, Vol. 64, pp 426-438, 2016, https://doi.org/10.1016/j.geothermics.2016.06.005

23. Dominković, D., Rashid, K., Romagnoli, A., Pedersen, A., Leong, K., Krajačić, G. and Duić, N., Potential of district cooling in hot and humid climates, Applied Energy, Vol. 208, pp 49-61, 2017, https://doi.org/10.1016/j.apenergy.2017.09.052

24. Facchini, A., Kennedy, C., Stewart, I. and Mele, R., The Energy Metabolism of Megacities, Applied Energy, Vol. 186, Part 2, pp 86-95, 2017, https://doi.org/10.1016/j.apenergy.2016.09.025

25. Ramachandra, T., Bajpai, V., Kulkarni, G., Aithal, B. and Han, S., Economic disparity and $\mathrm{CO}_{2}$ emissions: The Domestic Energy Sector in Greater Bangalore, India, Renewable and Sustainable Energy Reviews, Vol. 67, pp 1331-1344, 2017, https://doi.org/10.1016/j.rser.2016.09.038

26. Sun, W., Zhang, X., Li, H., Wu, J. and Zheng, S., Environmental Ideology and Household Energy conservation in Beijing, Journal of Cleaner Production (Article in press), pp 1-9, 2017, https://doi.org/10.1016/j.jclepro.2017.07.065

27. Frayssinet, L., Merlier, L., Kuznik, F., Hubert, J., Milliez, M. and Roux, J., Modeling the heating and cooling Energy demand of Urban Buildings at City Scale, Renewable and Sustainable Energy Reviews, Vol. 81, No. 2, pp 2318-2327, 2018, https://doi.org/10.1016/j.rser.2017.06.040

28. Qi, W., Deng, X., Chu, X., Zhao, C. and Zhang, F., Emergy analysis on Urban Metabolism by counties in Beijing, Physics and Chemistry of the Earth, Vol. 101, pp 157-165, 2017, https://doi.org/10.1016/j.pce.2017.01.024

29. Fan, J., Wang, J., Li, F., Yu, H. and Zhang, X., Energy demand and Greenhouse Gas emissions of Urban Passenger Transport in the Internet era: A Case Study of Beijing, 
Journal of Cleaner Production, Vol. 165, pp 177-189, 2017, https://doi.org/10.1016/j.jclepro.2017.07.106

30. Dias, M., Haddad, J., Nogueira, L., Bortoni, E., Cruz, R., Yamachita, R. and Goncalves, J., The impact on Electricity demand and emissions due to the introduction of Electric Cars in the São Paulo Power System, Energy Policy, Vol. 65, pp 298-304, 2014, https://doi.org/10.1016/j.enpol.2013.09.052

31. Spriet, J. and Hendrick, P., Wastewater as a Heat Source for Individual Residence Heating: A Techno-economic feasibility Study in the Brussels Capital Region, Journal of Sustainable Development of Energy, Water and Environment Systems, Vol. 5, No. 3, pp 289-308, 2017, https://doi.org/10.13044/j.sdewes.d5.0148

32. Hoek, van der J., Fooij, de H. and Struker, A., Wastewater as a Resource: Strategies to recover Resources from Amsterdam's Wastewater, Resources, Conservation and Recycling, Vol. 113, pp 53-64, 2016, https://doi.org/10.1016/j.resconrec.2016.05.012

33. Walker, R., Beck, M., Hall, J., Dawson, R. and Heidrich, O., The Energy-water-food Nexus: Strategic analysis of Technologies for transforming the Urban Metabolism, Journal of Environmental Management, Vol. 141, pp 104-115, 2014, https://doi.org/10.1016/j.jenvman.2014.01.054

34. Gondhalekar, D. and Ramsauer, T., Nexus City: Operationalizing the Urban Water-Energy-Food Nexus for Climate change adaptation in Munich, Germany, Urban Climate, Vol. 19, pp 28-40, 2017, https://doi.org/10.1016/j.uclim.2016.11.004

35. McDonald, R., Weber, K., Padowski, J., Flörke, M., Schneider, C., Green, P., Gleeson, T., et al., Water on an Urban Planet: Urbanization and the reach of Urban Water Infrastructure, Global Environmental Change, Vol. 27, pp 96-105, 2014, https://doi.org/10.1016/j.gloenvcha.2014.04.022

36. Lam, K., Kenway, S. and Lant, P., Energy use for Water Provision in Cities, Journal of Cleaner Production, Vol. 143, pp 699-709, 2017, https://doi.org/10.1016/j.jclepro.2016.12.056

37. Rygaard, M., Godskesen, B., Jørgensen, C. and Hoffmann, B., Holistic assessment of a Secondary Water Supply for a new development in Copenhagen, Denmark, Science of the Total Environment, Vol. 497-498, pp 430-439, 2014, https://doi.org/10.1016/j.scitotenv.2014.07.078

38. Loureiro, S. M., Rovere, E. L. L. and Mahler, C. F., Analysis of Potential for reducing emissions of Greenhouse Gases in Municipal Solid Waste in Brazil, in the State and City of Rio de Janeiro, Waste Management, Vol. 33, No. 5, pp 1302-1312, 2013, https://doi.org/10.1016/j.wasman.2013.01.024

39. Dubeux, C. and La Rovere, E., Local Perspectives in the Control of Greenhouse Gas Emissions - The Case of Rio de Janeiro, Cities, Vol. 24, No. 5, pp 353-364, 2007, https://doi.org/10.1016/j.cities.2007.01.012

40. Pacheco, E., Ronchetti, L. and Masanet, E., An Overview of Plastic recycling in Rio de Janeiro, Resources, Conservation and Recycling, Vol. 60, pp 140-146, 2012, https://doi.org/10.1016/j.resconrec.2011.12.010

41. Condeixa, K., Haddad, A. and Boer, D., Material Flow analysis of the Residential building Stock at the City of Rio de Janeiro, Journal of Cleaner Production, Vol. 149, pp 1249-1267, 2017, https://doi.org/10.1016/j.jclepro.2017.02.080

42. Andrade, M., Kumar, P., de Freitas, E., Ynoue, R., Martins, J., Martins, L., Nogueira, T., et al., Air Quality in the Megacity of São Paulo: Evolution over the last 30 years and Future perspectives, Atmospheric Environment, Vol. 159, pp 66-82, 2017, https://doi.org/10.1016/j.atmosenv.2017.03.051

43. Borge, R., Narros, A., Artíñano, B., Yagüe, C., Gómez-Moreno, F., de la Paz, D., Román-Cascón, D., et al., Assessment of Microscale Spatio-temporal variation of Air pollution at an Urban Hotspot in Madrid (Spain) through an extensive Field Campaign, Atmospheric Environment, Vol. 140, pp 432-445, 2016, https://doi.org/10.1016/j.atmosenv.2016.06.020 
44. García, P. and Pérez, E., Mapping of Soil sealing by vegetation Indexes and built-up Index: A Case Study in Madrid (Spain), Geoderma, Vol. 268, pp 100-107, 2016, https://doi.org/10.1016/j.geoderma.2016.01.012

45. Soares-Gomes, A., da Gama, B., Baptista Neto, J., Freire, D., Cordeiro, R., Machado, W., Bernardes, M., Coutinho, R., Thompson, F. and Pereira, R., An Environmental overview of Guanabara Bay, Rio de Janeiro, Regional Studies in Marine Science, Vol. 8, Part 2, pp 319-330, 2016, https://doi.org/10.1016/j.rsma.2016.01.009

46. Silva, M., Horta, I., Leal, V. and Oliveira, V., A spatially-explicit Methodological Framework based on Neural Networks to assess the effect of Urban Form on Energy demand, Applied Energy, Vol. 202, pp 386-398, 2017, https://doi.org/10.1016/j.apenergy.2017.05.113

47. Chatzipoulka, C., Compagnon, R. and Nikolopoulou, M., Urban Geometry and Solar availability on Façades and Ground of Real Urban Forms: using London as a Case Study, Solar Energy, Vol. 138, pp 53-66, 2016, https://doi.org/10.1016/j.solener.2016.09.005

48. Nello, O., López, J., Martín, J. and Checa, J., Energy and Urban Form: The growth of European Cities on the basis of Night-time brightness, Land Use Policy, Vol. 61, pp 103-112, 2017, https://doi.org/10.1016/j.landusepol.2016.11.007

49. Kabisch, N., Ecosystem Service implementation and Governance challenges in Urban Green Space planning - The Case of Berlin, Germany, Land Use Policy, Vol. 42, pp 557-567, 2015, https://doi.org/10.1016/j.landusepol.2014.09.005

50. $\mathrm{Hu}, \mathrm{M} ., \mathrm{Wu}, \mathrm{C}$. and Shih, T., Creating a new Socio-technical Regime in China: Evidence from the Sino-Singapore Tianjin Eco-City, Futures, Vol. 70, pp 1-12, 2015, https://doi.org/10.1016/j.futures.2015.04.001

51. Leeuwen, van R., Wit, de J. and Smit, G., Review of Urban Energy transition in the Netherlands and the Role of Smart Energy management, Energy Conversion and $\begin{array}{lllll}\text { Management, } & \text { Vol. } & \text { 150, }\end{array}$ https://doi.org/10.1016/j.enconman.2017.05.081

52. Dams $\varnothing$, T., Kjær, T. and Christensen, T., Implementation of Local Climate Action Plans: Copenhagen - Towards a Carbon-neutral Capital, Journal of Cleaner Production, Vol. 167, pp 406-415, 2017, https://doi.org/10.1016/j.jclepro.2017.08.156

53. Kılkış, Ş., Sustainable Development of Energy, Water and Environment Systems Index for Southeast European Cities, Journal of Cleaner Production, Vol. 130, pp 222-234, 2016, https://doi.org/10.1016/j.jclepro.2015.07.121

54. Kılkış, Ş., Composite Index for benchmarking Local Energy Systems of Mediterranean Port Cities, Energy, Vol. 92, Part 3, pp 622-638, 2015, https://doi.org/10.1016/j.energy.2015.06.093

55. Kılkış, Ş., Sustainable Development of Energy, Water and Environment Systems (SDEWES) Index for Policy Learning in Cities, International Journal on Innovation and Sustainable Development, Vol. 12, No. 1/2, pp 87-134, 2018, https://doi.org/10.1504/IJISD.2018.089263

56. Kılkış, Ş., Benchmarking South East European Cities with the Sustainable Development of Energy, Water and Environment Systems Index, Journal of Sustainable Development of Energy, Water and Environment Systems, Vol. 6, No. 1, pp 162-209, 2018, http://dx.doi.org/10.13044/j.sdewes.d5.0179

57. SDEWES Index, http://www.sdewes.org/sdewes_index.php, [Accessed: 25-February-2018]

58. SDEWES Centre, http://www.sdewes.org/home.php, [Accessed: 25-February-2018]

59. City of Amsterdam, Amsterdam: A Different Energy 2040 Energy Strategy, 2010, Amsterdam, Netherlands.

60. Amsterdam Climate Office, New Amsterdam Climate, http://mycovenant.eumayors.eu/docs/document/280_1323081175.pdf, [Accessed: 25-February-2018] 
61. Boogert, G., Mantel, B. and Fèvre, S., Amsterdam Status-Quo-Report Transform Project, Amsterdam, Netherlands, 2013.

62. City of Amsterdam, Energy Atlas Amsterdam Southeast, 2014.

63. City of Amsterdam, Sustainable Amsterdam: Agenda for Renewable Energy, Clear Air, a Circular Economy and a Climate-Resilient City, 2015.

64. City of Antwerp, Antwerp Climate Plan (in Dutch), Antwerp, Belgium, 2011.

65. City of Antwerp, Climate Plan Actualization (in Dutch), 2015.

66. Bangalore Climate Change Initiative, Karnataka Climate Change Action Plan, 2011.

67. Government of Karnataka, Karnataka State Action Plan on Climate Change $1^{\text {st }}$ Assessment, 2012.

68. Sridevi, H., Shreejith, K. and Ramachandra, T., Comparative analysis of Greenhouse Gas emissions from major Cities of India, International Journal of Renewable Energy and Environmental Engineering, Vol. 2, No. 1, pp 1-6, 2014.

69. Cleaner Energy Saving Mediterranean Cities Project, SEAP Batna Commune (in French), 2015.

70. People's Government of Beijing Municipality, The $12^{\text {th }}$ Five-Year Plan for Civil Buildings Energy Conservation (in Chinese), 2011.

71. China Statistics Press, Beijing Statistical Yearbook 2016, 2016, http://www.bjstats.gov.cn/nj/main/2016-tjnj/zk/indexeh.htm, [Accessed: 25-February-2018]

72. Berliner Energieagentur GmbH - IÖW, Energy Concept 2020 (in German), 2011.

73. Amt für Statistik Berlin-Brandenburg, Energy and $\mathrm{CO}_{2}$ balance in Berlin 2014 Statistical Report (in German), 2017.

74. City Council of Bilbao, Sustainable Energy Action Plan (in Spanish), 2012.

75. Municipality of Braga, Sustainable Energy Action Plan (in Portuguese), 2014.

76. City of Bregenz, Sustainable Energy Action Plan (in German), 2012.

77. City of Bregenz, Sustainable Energy Action Plan Monitoring Report (in German), 2015.

78. City of Bydgoszcz, SEAP for the City of Bydgoszcz for 2012-2020 (in Polish), 2012.

79. Copenhagen Municipality, $\mathrm{CO}_{2}$ Neutral in 2025 - Copenhagen's Climate Plan (in Danish), 2011.

80. Copenhagen Municipality, Copenhagen Environmental Report 2014 (in Danish), 2015.

81. SparEnergi, Energy and $\mathrm{CO}_{2}$ Accounts Copenhagen Municipality 2015 (in Danish), 2017.

82. Municipality of Florence, SEAP of the Municipality of Florence (in Italian), 2011.

83. Municipality of Florence, Monitoring Report 2017, http://www.covenantofmayors.eu/ about/covenant-community/signatories/progress.html?scity_id=3691,

[Accessed: 25-February-2018]

84. City of Gothenburg, Climate Programme for Gothenburg, 2014.

85. City of Gothenburg, The Energy Efficient City, 2014.

86. City of Gothenburg, Monitoring Report 2015, http://www.covenantofmayors.eu/ about/covenant-community/signatories/progress.html?scity_id=1884,

[Accessed: 25-February-2018]

87. Grand Lyon, Climate Plan Greater Lyon Action Plan (in French), 2012.

88. Grand Lyon, Territorial Climate and Energy Plan Progress Report 2015, 2015.

89. OREGES Auvergne-Rhône-Alpes, Energy-climate Profile 2014 (in French), 2017.

90. The City of Helsinki, Mayor's Energy and Climate Agreement (in Finnish), 2010.

91. The City of Helsinki, Monitoring Report 2017, http://www.covenantofmayors.eu /about/covenant-community/signatories/progress.html?scity_id=1765,

[Accessed: 25-February-2018]

92. Helsinki Region Environmental Services, Greenhouse Gas emissions from the Metropolitan Area (in Finnish), https://hsy.fi/fi/asiantuntijalle/ilmastonmuutos/ hillinta/seuranta/Sivut/Paastot.aspx, [Accessed: 25-February-2018] 
93. City of Karlovac, Sustainable Energy Action Plan (in Croatian), 2012.

94. Ekonerg, Central Heat System Development Plan in the City of Karlovac (in Croatian), 2015.

95. City of Karlovac, Monitoring Report 2017, http://www.covenantofmayors.eu/about/ covenant-community/signatories/progress.html?scity_id=2943,

[Accessed: 25-February-2018]

96. Greater London Authority, Delivering London's Energy Future, the Mayor's Climate Change and Energy Strategy, 2011.

97. Greater London Authority, London Heat Network Manual, 2014.

98. Greater London Authority Environment Committee, Cutting Carbon in London Update, 2015.

99. London Energy and Greenhouse Gas Inventory 2014, https://data. london.gov.uk/dataset/leggi, [Accessed: 25-February-2018]

100. City of Lviv, Sustainable Energy Development Program of Lviv to 2020, 2011.

101. City of Lviv, Implementation of Mitigation Actions 2015, http://www.covenantof mayors.eu/about/covenant-community/signatories/progress.html?scity_id=1898, [Accessed: 25-February-2018]

102. City of Madrid, Horizon 2020 Energy and Climate Change Plan (in Spanish), 2014.

103. City of Madrid, Energy Balance of the Municipality of Madrid 2014 (in Spanish), 2016.

104. City of Madrid, Emissions Inventory of the Municipality of Madrid 2014 (in Spanish), 2016.

105. City of Porto, Sustainable Energy Action Plan (in Portuguese), 2010.

106. Energy Agency of Porto AdEPorto, Energy Matrix of the Metropolitan Area of Porto (in Portuguese), 2014.

107. City of Rio de Janeiro - Centro Clima/COPPE/UFRJ, Greenhouse Gas Emissions Inventory of the City of Rio de Janeiro in 2012 and updating of the Municipal Plan of Action for Emissions Reduction, 2013.

108. Global Covenant of Mayors, Rio de Janeiro City Profile, https://www.globalcovenantofmayors.org/cities/rio-de-janeiro/\#profile, [Accessed: 25-February-2018]

109. City of Salé, Baseline Energy Inventory and Sustainable Energy Action Plan of Salé, 2011.

110. Municipality of São Paulo, Update of the Inventory of Emissions and Anthropogenic Removals of Greenhouse Gases of the Municipality of São Paulo for the years 2010 and 2011, 2012.

111. Tianjin Municipal People's Government, The $12^{\text {th }}$ Five-Year Plan for Energy Conservation (in Chinese), 2012.

112. China Statistics Press, Tianjin Statistical Yearbook 2016, 2016, http://61.181.81.253/nianjian/2016nj/zk/indexeh.htm, [Accessed: 25-February-2018]

113. Municipality of V. N. Gaia, Sustainable Energy Plan of Vila Nova de Gaia (in Portuguese), 2011.

114. Municipality of V. N. Gaia, First Evaluation Report (in Portuguese), 2014.

115. Vilnius City, Sustainable Energy Action Plan (in Lithuanian), 2013.

116. Vilnius City, Assessment of Sustainable Energy and Climate Change Indicators of Vilnius City (in Lithuanian), 2015.

117. Lunenburg, F., Managing change: The role of the change agent, International Journal of Management, Business, and Administration, Vol. 13, No. 1, pp 1-6, 2010.

118. Genus, A. and Theobald, K., Roles for University Researchers in Urban Sustainability Initiatives: The UK Newcastle Low Carbon Neighbourhoods Project, Journal of Cleaner Production, Vol. 106, pp 119-126, 2015, https://doi.org/10.1016/j.jclepro.2014.08.063 
119. SDEWES, $11^{\text {th }}$ SDEWES Conference Lisbon 2016, http://www.lisbon2016. sdewes.org/, [Accessed: 25-February-2018]

120. OECD JRC, Handbook on Constructing Composite Indicators: Methodology and User Guide, OECD Publishing, Paris, France, 2008.

121. Kılkış, Ş., Benchmarking the Sustainability of Urban Energy, Water and Environment Systems with the SDEWES City Index and Envisioning Scenarios for the Future, Invited Lecture, 12 ${ }^{\text {th }}$ SDEWES Conference, Dubrovnik, Croatia, 2017.

122. Saisana, M., A do-it-yourself Guide in Excel for Composite Indicator development, European Commission JRC-COIN, Ispra, Italy, 2012.

123. SDEWES, $1^{\text {st }}$ Latin American SDEWES Conference, Rio de Janeiro, Brazil, 2018, http://www.rio2018.sdewes.org/, [Accessed: 25-February-2018]

124. City of Rio de Janeiro, The Rio of Tomorrow: Vision Rio 500 and Strategic Planning 2017-2020 (in Portuguese), pp 1-399.

125. C40 Cities, City Adviser Case Study Series: City of Rio de Janeiro- Climate change planning through Direct Support, http://www.c40.org/case_studies/city_adviser_rio, [Accessed: 25-February-2018]

126. 25 Cities Commit to become Emissions Neutral by 2050 to Deliver on their Share of the Paris Agreement, http://www.c40.org/press_releases/25-cities-emissions-neutralby-2050, [Accessed: 25-February-2018]

127. Ogilvy, J., Futures Studies and the Human Sciences: The Case for Normative Scenarios, Futures Research Quarterly, Vol. 8, No. 2, pp 5-65, 1992.

128. Kona, A., Melica, G., Koffi, B., Iancu, A., Zancanella, P., Calvete, S., Bertoldi, P., Janssens- Maenhout, G. and Monforti-Ferrario, F., Covenant of Mayors: Greenhouse Gas Emissions Achievements and Projections, JRC Science for Policy Report 2016.

129. NREL National Renewable Energy Laboratory NASA Atmospheric Science Data Center Datasets, http://maps.nrel.gov/swera, [Accessed: 25-February-2018]

130. Enerdata, Energy Efficiency Indicators: Ratio Final/Primary Intensity, 2016.

131. IEA ECBCS Annex 49, Summary Report: Low Exergy Systems for High Performance Buildings and Communities (Schmidt, D. and Torío, H. eds), Fraunhofer - IBP, Stuttgart, Germany, 2011.

132. Kılkış, Ş., Energy System analysis of a Pilot Net-zero Exergy District, Energy Conversion and Management, Vol. 87, pp 1077-1092, 2014, https://doi.org/10.1016/j.enconman.2014.05.014

133. Lund, H., Werner, S., Wiltshire, R., Svendsen, S., Thorsen, J., Hvelplund, F. and Vad Mathiesen, B., $4^{\text {th }}$ Generation District Heating (4GDH) integrating Smart Thermal Grids into Future Sustainable Energy Systems, Energy, Vol. 68, pp 1-11, 2014, https://doi.org/10.1016/j.energy.2014.02.089

134. Danish Energy Agency - Danish Board of District Heating - State of Green, District Heating - Danish Experiences, https://ens.dk/sites/ens.dk/files/contents/material/file/dh_danish_experiences.pdf, [Accessed: 25-February-2018]

135. Riipinen, M., District heating and cooling in Helsinki, International Energy Agency CHP/DHC Collaborative, 2013.

136. Energiewende, Low-exergy transmission pipes for storing and distributing heat, 2017.

137. Stratego Project, Multi-level actions for enhanced heating and cooling plans - City of Antwerp,

http://stratego-project.eu/wp-content/uploads/2014/09/3a-STRATEGO-local-cases-B E-Antwerp.pdf, [Accessed: 25-February-2018]

138. Ministry of Energy, Lithuanian District Heating Sector: Present Situation and Future of the Lithuanian Energy Market, 2015.

139. ICLEI, District Energy Systems: Towards efficient cooling for Buildings in India's Cities, 2016. 
140. City of Rio de Janeiro, Energy Toolkit for Buildings Rio de Janeiro, 2014, https://riorenewables.com/, [Accessed: 25-February-2018]

141. European Commission, EU Building Stock Observatory Database, https://ec.europa.eu/energy/en/eu-buildings-database, [Accessed: 25-February-2018]

142. European Commission, Guidelines for the promotion of nearly Zero-energy Buildings and best practices to ensure that, by 2020 , all new Buildings are nearly Zero-energy Buildings, Official Journal of the European Union 2016/1318, 2016.

143. ZED Factory Europe Ltd., Beddington Zero Energy Development (BedZED), https://www.zedfactory.com/bedzed, [Accessed: 25-February-2018]

144. Construction 21 International, China Academy of Building Research NZEB Building, https://www.construction21.org/case-studies/h/china-academy-of-building-research-n zebuilding.html, [Accessed: 25-February-2018]

145. PassREg Project, Beacon Brochure: Nieuw Zuid Urban development, http://www.eneffect.bg/images/upload/Proekti/PassREg/Beacon\%20brochure.pdf, [Accessed: 25-February-2018]

146. Ortego, A., Valero, A. and Abadías, A., Environmental impacts of promoting new Public Transport Systems in Urban Mobility: A Case Study, Journal of Sustainable Development of Energy, Water and Environment Systems, Vol. 5, No. 3, pp 377-395, 2017, https://doi.org/10.13044/j.sdewes.d5.0143

147. TomTom Traffic Index, Measuring Congestion Worldwide, https://www.tomtom.com/en_gb/trafficindex/, [Accessed: 25-February-2018]

148. Amsterdam Smart City, Smart Street Lighting powered by direct Current at Port of Amsterdam, https://amsterdamsmartcity.com/projects/smart-street-lighting-poweredby-direct-current-at-port-of-amsterdam-4t01ug3v, [Accessed: 25-February-2018]

149. World Bank - Municipality of Rio de Janeiro, Realizing Energy Efficiency Opportunities in Rio de Janeiro, ESMAP Program Trace.

150. Ambiente Italia, Urban Ecosystem (in Italian) XXIII Environmental Quality Report of the Provincial Capitals, 2016.

151. Meldrum, J., Nettles-Anderson, S., Heath, G. and Macknick, J., Life Cycle Water use for Electricity Generation: A Review and Harmonization of Literature estimates, Environmental Research Letters, Vol. 8, pp 1-18, 2013., https://doi.org/10.1088/1748-9326/8/1/015031

152. IRENA, REthinking Energy 2017: Accelerating the Global Energy transformation, Abu Dhabi, UAE, 2017.

153. JRC Photovoltaic Geographical Information System (PVGIS) Incident Global Irradiation for the Chosen Location, http://re.jrc.ec.europa.eu/pvg_tools/en/tools.html, [Accessed: 25-February-2018]

154. IRENA/DTU, Global Atlas for Renewable Energy DTU Global Wind Atlas Wind Speed Maps, https://irena.masdar.ac.ae/gallery/\#tool/10, [Accessed: 25-February-2018]

155. GENI Global Energy Research Institute, Atlas of Geothermal Resources in Europe Heat-flow

Density, http://www.geni.org/globalenergy/library/renewable-energy-resources/world/europe/ geo-europe/index.shtml, [Accessed: 25-February-2018]

156. Enerdata, Global Energy Statistical Yearbook, 2017.

157. IEA Statistics by Country Balances and Electricity and Heat Reports, http://www.iea.org/statistics/statisticssearch/, [Accessed: 25-February-2018]

158. City of Sydney, Environmental Action 2016-2021 Strategy and Action Plan, 2017.

159. Hoekstra, A., Chapagain, A., Aldaya, M. and Mekonnen, M., Water Footprint assessment Manual: Setting the Global Standard, Earthscan, London, UK, 2011.

160. Ercin, A., Mekonnen, M. and Hoekstra, A., The Water footprint of France, value of Water, Research Report Series, No. 56, 2012. 
161. Younos, T. and Parece, T. (eds.), Sustainable Water management in Urban Environments, Handbook of Environmental Chemistry Series, Vol. 47, Springer Switzerland, Cham, Switzerland, 2016, https://doi.org/10.1007/978-3-319-29337-0

162. Carr, G. and Rickwood, C., Water Quality: Development of an Index to assess Country Performance, UNEP GEMS/Water Programme, 2008.

163. Mcdavid, N., The Truth About Water Quality in Finland, https://borgenproject.org/the-truth-about-water-quality-in-finland/, [Accessed: 25-February-2018]

164. Abdelhakim, H. and Rachid, G., Environmental Context of the Wastewater treatment Plant of Batna (Algeria), International Journal of Waste Resources, Vol. 7, No. 2, pp 1-5, 2017, https://doi.org/10.4172/2252-5211.1000274

165. WHO Ambient (Outdoor) Air pollution in Cities Database 2014, http://www.who.int/phe/health_topics/outdoorair/databases/cities/en/, [Accessed: 20-December-2015]

166. WHO Ambient (Outdoor) Air pollution in Cities Database 2016, http://www.who.int/phe/health_topics/outdoorair/databases/cities/en/, [Accessed: 25-February-2018]

167. Jia, H. and Wang, L., Peering into China's thick haze of Air Pollution, Chemical and Engineering News, Vol. 95, No. 4, pp 19-22, 2017.

168. Guan, W., Zheng, X., Chung, K. and Zhong, N., Impact of Air Pollution on the burden of Chronic Respiratory Diseases in China: Time for urgent action, Lancet, Vol. 388, pp 1939-1951, 2016, https://doi.org/10.1016/S0140-6736(16)31597-5

169. Borucke, M., Moore, D., Cranston, G., Gracey, K., Katsunori, I., Larson, J., Lazarus, E., Morales, J. C., Wackernagel, M. and Galli, A., Accounting for demand and supply of the Biosphere's Regenerative Capacity: The National Footprint Accounts' underlying Methodology and Framework, Ecological Indicators, Vol. 24, pp 518-533, 2013, https://doi.org/10.1016/j.ecolind.2012.08.005

170. WWF - Global footprint Network, China Ecological footprint Report: Consumption, production and sustainable development, 2012.

171. OECD - International Transport Forum, Shared Mobility Simulations for Helsinki, Case-Specific Policy Analysis Report, 2017.

172. World Footprint Network, Water footprint statistics, http://waterfootprint.org/en/resources/water-footprint-statistics/,

[Accessed: 25-February-2018]

173. Hoekstra, A. and Mekonnen, M., The Water Footprint of Humanity, Proceedings of the National Academy of Sciences, Vol. 109, No. 9, pp 3232-3237, 2012, https://doi.org/10.1073/pnas.1109936109

174. Carr, G. and Rickwood, C., Water Quality: Development of an Index to assess Country performance, UNEP GEMS/Water Programme, 2008.

175. Srebotnjak, T., Carr, G., Sherbinin, A. and Rickwood, C., A Global Water Quality Index and Hot-Deck imputation of missing Data, Ecological Indicators, Vol. 17, pp 108-119, 2012, https://doi.org/10.1016/j.ecolind.2011.04.023

176. GFN Global Footprint Network National footprint Accounts - National Ecological footprint and biocapacity, http://www.footprintnetwork.org, [Accessed: 25-February-2018]

177. Nederlandse Spoorwegen, Sustainable Energy, https://www.ns.nl/en/about-ns/sustainability/energy/sustainable-energy.html, [Accessed: 25-February-2018]

178. Nellore, A. J., Eight Global Rail Projects harnessing the Power of Solar Energy, https://www.smartrailworld.com/7-global-rail-projects-harnessing-the-power-of-solar -energy, [Accessed: 25-February-2018] 
179. Kilkış, Ş., A Rational Exergy Management Model to curb $\mathrm{CO}_{2}$ emissions in the Exergy-aware built Environments of the Future, Ph.D. Thesis, KTH Royal Institute of Technology School of Architecture and the Built Environment, Stockholm, Sweden, 2011.

180. CoM, Monitoring Action Plans, http://www.covenantofmayors.eu/actions/monitoring -action-plans_en.html, [Accessed: 25-February-2018]

181. Persson, U., Möller, B., Wiechers, E. and Rothballer, C., Maps Manual for Lead-Users, Heat Roadmap Europe 2050, 2017.

182. Heat Roadmap Europe, Pan-European Thermal Atlas 4, http://www.heatroadmap.eu/maps.php, 2017, [Accessed: 25-February-2018]

183. Kılkış, Ş. And Kılkış, Ş., Benchmarking Airports based on a Sustainability Ranking Index, Journal of Cleaner Production, Vol. 130, pp 248-259, 2016, https://doi.org/10.1016/j.jclepro.2015.09.031

184. European Power to Gas Platform, Power-to-gas demonstration Projects in Europe, http://www.europeanpowertogas.com/demonstrations, [Accessed: 25-February-2018]

185. Krishnan, D. and Dellesky, C., Bangalore's Airport to become a Leader in Solar Energy production, WRI Ross Center for Sustainable Cities, 2016.

186. Finavia Airports, Helsinki Airport goes Solar Energy - Finavia supports the International Climate agreement through its Climate Programme, 2017.

187. ACI Airport Carbon Accreditation, Accredited Airports around the World, http://www.airportcarbonaccreditation.org/airport/participants.html,

[Accessed: 25-February-2018]

188. Ecorys, Study on European Energy Intensive Industries - The usefulness of estimating Sectoral Price Elasticities, pp 1-131, 2009.

189. European Commission, Quality of Life in European Cities, Flash Eurobarometer 419, 2016.

190. Environment Council, The EU sets new targets for Waste management, https://www.eu2017.ee/news/press-releases/eu-sets-new-targets-waste-management, [Accessed: 25-February-2018]

191. European Commission, Ninth Report on the Implementation Status and the Programmes for Implementation of Council Directive 91/271/EEC concerning Urban Waste Water Treatment, Brussels, Belgium, 2017.

192. Stefanović, G., Milutinović, B., Vučićević, B., Denčić-Mihajlov, K. and Turanjanin, V., A comparison of the Analytic Hierarchy Process and the analysis and synthesis of parameters under Information deficiency method for assessing the sustainability of Waste management Scenarios, Journal of Cleaner Production, Vol. 130, pp 155-165, 2016, https://doi.org/10.1016/j.jclepro.2015.12.050

193.Zero Waste Europe, Zero Waste Hierarchy of highest and best use, http://zerowasteeurope.eu/about/principles-zw-europe/, [Accessed: 25-February-2018]

194. European Environment Agency, Urban Waste Water Treatment Map, https://www.eea.europa.eu/themes/water/water-pollution/uwwtd/interactive-maps/ urban-waste-water-treatment-maps, [Accessed: 25-February-2018]

195. Gawlik, B. M., Easton, P., Koop, S., Van Leeuwen, K., Elelman, R. (eds.), Urban Water Atlas for Europe, European Commission, Publications Office of the European Union, Luxembourg, Luxembourg, 2017.

196. OECD, OECD Metropolitan Areas Database, www.oecd.org/gov/regional/measuringurban, [Accessed: 25-February-2018]

197. IPCC Working Group III, Human Settlements, Infrastructure and Spatial planning, $5^{\text {th }}$ Assessment Report: Climate change 2014: Mitigation of Climate change, 2013.

198. Cereda, V., Compact City and densification Strategies: The Case of Gothenburg, M.Sc. Thesis, Blekinge Tekniska Högskola, Karlskrona, Sweden, 2009. 
199. Kaczorowska, A., Kain, J., Kronenberg, J. and Haase, D., Ecosystem Services in Urban Land use planning: Integration challenges in Complex Urban settings - Case of Stockholm, Ecosystem Services, Vol. 22, Part A, pp 204-212, 2016, https://doi.org/10.1016/j.ecoser.2015.04.006

200. European Climate Adaptation Platform, http://climate-adapt.eea.europa.eu/ knowledge/tools/urban-adaptation/climatic-threats/heat-waves/exposure, [Accessed: 25-February-2018]

201. IWA, City Water Stories: Gothenburg, http://www.iwa-network.org/city/gothenburg/, [Accessed: 25-February-2018]

202. The Economist Intelligence Unit, The Global Liveability Report, 2017.

203. UNESCO, Sustainable development begins with education, Paris, 2014.

204. Eurostat, Municipal Waste by NUTS 2 Regions - Pilot Project Data, 2016.

205. D-WASTE Hellas Ltd. Athens, Waste Atlas, http://www.atlas.d-waste.com/, [Accessed: 25-February-2018]

206. European Commission, Assessment of separate Collection Schemes in the 28 Capitals of the EU, 2015.

207. City of Gothenburg, Waste Statistics (Avfallsstatistik), http://goteborg.se/wps/portal/start/kommun-o-politik/kommunens-organisation/forvalt ningar/orvaltningar/forvaltningen-kretslopp-och-vatten/,

[Accessed: 25-February-2018]

208. Urban Waste Water Treatment Directive Site for Europe, http://uwwtd.oieau.fr/, [Accessed: 25-February-2018]

209. United Nations Economic Commission for Africa, Morocco Environmental Performance Reviews, Environmental Performance Review Series, No. 38, 2014.

210. Food and Agriculture Organization, Aquastat Municipal Wastewater production, collection, treatment and use Database, http://www.fao.org/nr/water/aquastat/ wastewater/index.stm\#db, [Accessed: 25-February-2018]

211. EEA Percentage of Green Urban Areas in EU-27 Core Cities, https://www.eea.europa.eu/data-and-maps/figures/percentage-of-green-urban-areas-1, [Accessed: 25-February-2018]

212. IUCN World Database on protected Areas, http://www.protectedplanet.net/, [Accessed: 25-February-2018]

213. Ramsar Sites Information Service, https://rsis.ramsar.org/, [Accessed: 25-February-2018]

214. World Bank GDP per Capita PPP International Dollars, http://data.worldbank.org/indicator/NY.GDP.PCAP.PP.CD,

[Accessed: 25-February-2018]

215. Gallup, Behavioral Economics of GDP growth and Global wellbeing, Washington D. C., USA, 2010.

216. Eurostat, Education and training Database, http://ec.europa.eu/eurostat/web/education-and-training/data/database, [Accessed: 25-February-2018]

217. OECD, Education Policy Outlook Country Profiles, http://www.oecd.org/edu/profiles.htm, [Accessed: 25-February-2018]

218. Barro, R. and Lee, J., A new Data set of Educational attainment in the World, http://www.barrolee.com/, [Accessed: 25-February-2018]

219. Fuhr, H., Hickmann, T. and Kern, K., The Role of Cities in Multi-level Climate Governance: Local Climate Policies and the $1.5{ }^{\circ} \mathrm{C}$ Target, Current Opinion in Environmental Sustainability, Vol. 30, pp 1-6, 2018, https://doi.org/10.1016/j.cosust.2017.10.006

220. Federal Ministry of Education and Research, The new High-Tech Strategy innovations for Germany. 
221. GIZ, Financing Sustainable Urban Transport: International Review of National Urban Transport Policies and Programmes, pp 1-52, 2013.

222. EU Smart Cities Information Systems, SCIS demonstration and Urban planning Projects, [Accessed: 25-February-2018]

223. EPO, Finding Sustainable Technologies in Patents, Munich, 2013.

224. SCImago Institutions Rankings, http://scimagoir.com/rankings.php, [Accessed: 25-February-2018]

225. SCImago, SCImago Institutions Rankings Methodology, http://www.scimagoir.com/methodology.php, [Accessed: 25-February-2018]

226. Amsterdam Institute for Metropolitan Solutions, https://www.ams-institute.org/, [Accessed: 25-February-2018]

227. JRC Research and Innovation Observatory (RIO), https://rio.jrc.ec.europa.eu/en, [Accessed: 25-February-2018]

228. OECD/UNESCO, Main Science, Technology and Innovation Statistics Database (June 2017 Release), 2017.

229. EPO European Patent Office Espacenet, http://www.epo.org/searching/free/espacenet.html, [Accessed: 25-February-2018]

230. SCImago Research Group Journal \& Country Rank, http://www.scimagojr.com/countrysearch.php, [Accessed: 25-February-2018]

231. C40 Cities, Cities 100: Copenhagen - Carbon Neutral district heating, 2015.

232. Riipinen, M., City Energy System in Helsinki, IEA Renewable heating and cooling Policy Workshop, 2017.

233. Tay, J. and Show, K., Utilization of Municipal Wastewater Sludge as building and construction Materials, Resources, Conservation and Recycling, Vol. 6, No. 3, pp 191-204, 1992, https://doi.org/10.1016/0921-3449(92)90030-6

234. Jiang, D., Ni, G. and Ma., G., Reuse of Municipal Wastewater Sludge for construction Material, Advanced Materials Research, Vol. 156-157, pp 939-942, 2011, https://doi.org/10.4028/www.scientific.net/AMR.156-157.939

235. City of Rio de Janeiro, Qualiverde Legislation for Green Buildings (in Portuguese), 2013.

236. Trata Brasil, Sanitation Ranking of the 100 Largest Cities (in Portuguese), 2017.

237. Royal Haskoning DHV, First South American Nereda Plant celebrates a Year in Operation, 2017.

238. IEA, Energy Technology Perspectives 2017 - Catalysing Energy Technology Transformations, Paris, France, 2017.

239. Odgaard, O., China's Quest for new district heating reforms, Policy Brief No. 3, 2015.

240. Rong, L., Present and Future of Beijing district heating, 2015.

241. Bayar, T., Cogen to replace Coal in Beijing Power Project, http://www.decentralizedenergy.com/articles/2015/09/cogen-to-replace-coal-in-beijing-power-project.html, [Accessed: 25-February-2018]

242. São Paulo Energy Secretary, São Paulo Energy Plan PPE (in Portuguese), 2012.

243. Liang, J. and Chen, L., The district heating in China, M.Sc. Thesis, University of Gävle, Gävle, Sweden, 2009.

244. Gong, M. and Werner, S., District heating research in China, Svensk Fjärrvärme AB, 2014.

245. BPIE, Nearly Zero Energy Buildings definitions across Europe, http://www.ediltecnico.it/wp-content/uploads/2015/05/BPIE_factsheet_nZEB_ definitions_across_Europe.pdf, [Accessed: 25-February-2018]

246. D’Agostino, D., Zangheri, P., Cuniberti, B., Paci, D. and Bertoldi, P., Synthesis Report on the National Plans for Nearly Zero Energy Buildings (NZEBs), JRC, Ispra, Italy, 2016. 
247. BREEAM, Case Studies: The Edge, Amsterdam, https://www.breeam.com/case-studies/offices/the-edge-amsterdam/,

[Accessed: 25-February-2018]

248. Erhorn, H. and Erhorn-Kluttig, H., Selected examples of Nearly Zero-Energy Buildings, 2014.

249. Rhomberg Bau Austria, First shared passive House Residential Area created in Bregenz, 2008.

250. Bolminger, S., Älvstranden Utveckling AB: Step by Step towards Energy efficient housing, 2016.

251. Next

Buildings,

Lyon-Confluence, http://next-buildings.eu/index.php/about/hikaribuilding,

[Accessed: 25-February-2018]

252. Lenoir, A., Garde, F., Ottenwelter, E., Bornarel, A. and Wurtz, E., Net Zero Energy building in France: From design Studies to Energy monitoring, A state of the art review, International Conference on Solar Heating, Cooling and Buildings, 2010, https://doi.org/10.18086/eurosun.2010.06.12

253. ZED Factory Europe Ltd., Beddington Zero Energy development (BedZED), https://www.zedfactory.com/bedzed, [Accessed: 25-February-2018]

254. Build Up, EspaiZero: A Semi-retrofit of an existing Building into the first Net Zero-Energy experience in Spain, 2014.

255. Build Up, LUCIA: Pioneer Energy autonomous Public building in Spain, 2016.

256. Fossati, M., Scalco, V., Linczuk, V. and Lamberts, R., Building Energy efficiency: An overview of the Brazilian Residential labeling Scheme, Renewable and Sustainable Energy Reviews, Vol. 65, pp 1216-1231, 2016, https://doi.org/10.1016/j.rser.2016.06.048

257. Singapore Government, Sino-Singapore Tianjin Eco-City KPIs, https://www.tianjinecocity.gov.sg/bg_kpis.htm, [Accessed: 25-February-2018]

258. BASF, BASF and Sino-Singapore Tianjin Eco-city to build World's tallest passive House,

https://www.basf.com/tw/en/company/news-and-media/news-releases/asia-pacific/20 15/10/tianjin-passive-house.html, [Accessed: 25-February-2018]

259. Demographia, Demographia World Urban Areas, 13 ${ }^{\text {th }}$ Annual Edition: 2017:04, 2017.

260. Transport for London, London Trams, https://tfl.gov.uk/corporate/about-tfl/what-we-do/london-trams?intcmp=2647, [Accessed: 25-February-2018]

261. Serradell, J. and Kennes, J., World Metro Database, http://mic-ro.com/metro/table.html, 2017, [Accessed: 25-February-2018]

262. Eltis Urban Mobility observatory, Karlovac trials Public Bicycle Scheme, 2015, http://www.eltis.org/discover/news/karlovac-trials-public-bicycle-scheme-croatia, [Accessed: 25-February-2018]

263. Juan, D., Beijing likes shared Bicycles - However, China Daily, 2017, http://www.chinadaily.com.cn/china/2017-05/02/content_29159869.htm, [Accessed: 25-February-2018]

264. ITDP, Regulating Dockless Bikeshare: Lessons from Tianjin China, 2018.

265. Department of Science and Technology, Research and Development Statistics at a Glance, 2017. 


\section{SUPPLEMENTARY MATERIAL}

Table A1. Energy system characteristics based on original compilations

\begin{tabular}{|c|c|c|c|c|c|}
\hline \multirow{4}{*}{ City $\left(C_{j}\right)$} & \multicolumn{5}{|c|}{ HOB/electric HVAC or DH only } \\
\hline & \multicolumn{5}{|c|}{$\mathrm{CHP}$ based $\mathrm{DH} / \mathrm{C}$} \\
\hline & \multicolumn{5}{|c|}{ Geothermal/solar, GHSP, seawater HP } \\
\hline & \multicolumn{5}{|c|}{ Integration of other sources (waste heat) } \\
\hline Amsterdam & $\checkmark$ & & $\mathrm{P}$ & & $\begin{array}{l}\text { DHN supplies } 62,000 \text { houses based on waste-to-energy and power plant; } \\
\text { Large-scale solar heat and geothermal will be integrated [63] }\end{array}$ \\
\hline Antwerp & $\checkmark$ & $\checkmark$ & $\mathrm{P}$ & $\mathrm{P}$ & $\begin{array}{l}747 \mathrm{MW} \text { CHP is installed mostly in the port [65], waste heat from the port is } \\
\text { planned to be used for Nieuw Zuid district heating [137] }\end{array}$ \\
\hline Bangalore & $\checkmark$ & & & & $\begin{array}{l}\text { Biomass cogeneration in } 54 \text { new and old sugar mills is expected to supply } \\
600 \mathrm{MW} \text { to the grid; } 3 \mathrm{MW} \text { solar PV plants are installed [66] }\end{array}$ \\
\hline Batna & $\checkmark$ & & & & $\begin{array}{l}\text { Pilot schools and campuses will implement PV and collective solar water } \\
\text { heaters for student housing to support national targets [69] }\end{array}$ \\
\hline Beijing & & $\checkmark$ & & $\mathrm{P}$ & $\begin{array}{l}\text { DH energy mix has } 70 \% \text { natural gas [239] with } 4 \text { CHP plants [240]; } \\
\text { Beijing Huaneng project includes new } 1,100 \mathrm{MW}_{\mathrm{e}} \mathrm{CHP} \text { plant [241] }\end{array}$ \\
\hline Berlin & & $\checkmark$ & $\mathrm{P}$ & & $\begin{array}{l}38 \% \text { of Berlin's electricity market and } 98 \% \text { of district heating }(1,600 \mathrm{~km}) \text { is } \\
\text { based on CHP while biomass based CHP units are planned [72] }\end{array}$ \\
\hline Bilbao & $\checkmark$ & $\mathrm{P}$ & & & $\begin{array}{l}\text { 1.2 } \mathrm{MW}_{\mathrm{e}} \mathrm{CHP} \text { plants are planned at various sites while a DHC network is } \\
\text { planned for } 1,100 \text { homes in the neighborhood of Bolueta [74] }\end{array}$ \\
\hline Braga & $\checkmark$ & $\mathrm{P}$ & $\mathrm{P}$ & & $\begin{array}{c}\text { Integrated renewable generation ( } \mathrm{PV} \text {, biomass } \mathrm{CHP} \text {, solar thermal) is planned } \\
\text { to reduce fossil fuel use by } 12,321 \mathrm{MWh} / \text { year [75] }\end{array}$ \\
\hline Bregenz & $\checkmark$ & & $\mathrm{P}$ & & $\begin{array}{c}\text { Biomass district heating reduces } \mathrm{CO}_{2} \text { emission by } 78 \text { tonnes per year; } \\
\text { heating and cooling with lakewater is being planned [76] }\end{array}$ \\
\hline Bydgoszcz & $\checkmark$ & $\mathrm{P}$ & & & $\begin{array}{l}\text { Existing } 3 \times 200 \mathrm{~kW}_{\mathrm{e}} \text { power plant produces biogas from landfill site; } \\
\text { renewable energy and CHP is targeted in SEAP [78] }\end{array}$ \\
\hline Copenhagen & & $\checkmark$ & $\checkmark$ & $\checkmark$ & $\begin{array}{l}\text { Biomass and waste DHN covers } 98 \% \text { of city; geothermal (Margretheholm) } \\
\text { and excess wind will be extended in 4GDH network [79] }\end{array}$ \\
\hline Florence & $\checkmark$ & $\mathrm{P}$ & & & $\begin{array}{l}\text { In addition to Careggi university DH, possible CHP and DH networks will be } \\
\text { analyzed for efficient buildings and areas by } 2020 \text { [82] }\end{array}$ \\
\hline Gothenburg & $\checkmark$ & $\checkmark$ & & $\checkmark$ & $\begin{array}{l}\text { DH based on residual heat from industrial processes, waste incineration, } \\
\text { and natural gas that will be replaced by biogas in } 2030 \text { [84] }\end{array}$ \\
\hline Grand Lyon & & $\checkmark$ & & & $\begin{array}{l}\text { Energy mix in the urban heating networks include } 20 \% \text { gas heating with } \\
\text { electricity cogeneration and } 32 \% \text { waste incineration [88] }\end{array}$ \\
\hline Helsinki & & $\checkmark$ & $\checkmark$ & $\checkmark$ & $\begin{array}{c}\text { CHP (Salmisaari, Hanasaari, Vuosaari) and Katri Vala plants with TES } 35 \mathrm{~m} \\
\text { below ground; } 14,500 \mathrm{DH} \text { and } 250 \mathrm{DC} \text { connections [232] }\end{array}$ \\
\hline Karlovac & $\checkmark$ & $\mathrm{P}$ & & & $\begin{array}{l}\text { Central heating plant has total installed capacity of } 116 \mathrm{MW} \text { and rated } \\
\text { temperatures } 120 / 70{ }^{\circ} \mathrm{C} \text {. CHP is analyzed for Tina Ujevića } 7 \text { [94] }\end{array}$ \\
\hline London & & $\checkmark$ & $\mathrm{P}$ & & $\begin{array}{c}\text { Pimlico 3.4 } \mathrm{MW}_{\text {th }}\left(3.1 \mathrm{MW}_{\mathrm{e}}\right) \text { and Whitehall CHP district-heating schemes are } \\
\text { being connected to increase base heat load [97] }\end{array}$ \\
\hline Lviv & $\checkmark$ & $\checkmark$ & & $\mathrm{P}$ & $\begin{array}{l}\text { CHP-1 with } 92.6 \% \text { efficiency and heating plants TC-Pivnichna-Pivdenna } \\
\text { support the DHN; CHP will be modernized [100] }\end{array}$ \\
\hline Madrid & & $\checkmark$ & $\checkmark$ & & $\begin{array}{l}51.7 \% \text { of the } 84.7 \text { ktoe of energy produced in Madrid is from CHP, } \\
21.6 \% \text { waste, } 12.9 \% \text { biogas, } 12.6 \% \text { solar thermal, } 1.1 \% \text { PV [102] }\end{array}$ \\
\hline Porto & $\checkmark$ & $\mathrm{P}$ & & & $\begin{array}{l}\text { Only } 3 \mathrm{CHP} \text { in the industry ( } 11 \mathrm{MW} \text { ) plus } 5 \mathrm{MW} \text { in licensing; } 2020 \text { targets } \\
\text { include 5,800 tonnes of } \mathrm{CO}_{2} \text { reduction from CHP [105] }\end{array}$ \\
\hline $\begin{array}{l}\text { Rio de } \\
\text { Janeiro }\end{array}$ & $\checkmark$ & & & & $\begin{array}{l}\text { Building-scale CCHP using biofuels to drive a chiller to provide cooling was } \\
\text { analyzed for the } 2016 \text { Rio Olympic Games [140] }\end{array}$ \\
\hline Salé & $\checkmark$ & & & & $\begin{array}{l}\text { Wood for heating may be replaced with methane driven CHP in the city; } \\
\text { Heat recovery in HVAC of public buildings is planned [109] }\end{array}$ \\
\hline São Paulo & $\checkmark$ & & & & $\begin{array}{c}\text { There is 4,300 MW of CHP in the state based on sugarcane bagasse (64\%) and } \\
\text { natural gas (13\%) in the industry and SME sector [242] }\end{array}$ \\
\hline Tianjin & $\checkmark$ & & & & $\begin{array}{l}\text { The share of district heating is } 93 \% \text { of heating area, which includes } 437 \text { boiler } \\
\text { houses and } 850 \text { boilers [243] with low efficiency [244] }\end{array}$ \\
\hline $\begin{array}{l}\text { Vila Nova } \\
\text { de Gaia }\end{array}$ & $\checkmark$ & & & & $\begin{array}{l}3 \mathrm{MW}_{\mathrm{e}} \text { biogas unit at Sermonde Landfill in Suldouro produces } 25,000 \mathrm{MWh} \\
\text { per year, target is } 5 \mathrm{MW}_{\mathrm{e}} \text { to produce } 40,000 \mathrm{MWh}[113]\end{array}$ \\
\hline Vilnius & $\checkmark$ & $\checkmark$ & & $\mathrm{P}$ & $\begin{array}{l}\text { Vilnius heat facilities will be modernized with energy sources of wastewater } \\
\text { treatment, waste incineration and increased biomass [115] }\end{array}$ \\
\hline
\end{tabular}


Table A2. Sub-indicators for nZEB implementations in cities

\begin{tabular}{|c|c|c|c|c|c|}
\hline \multirow[b]{2}{*}{ City $\left(C_{j}\right)$} & \multirow{2}{*}{$\begin{array}{c}\text { National } \\
\text { nZEB } \\
\text { plan }^{\mathrm{a}}\end{array}$} & \multicolumn{3}{|c|}{ nZEB definition from [245] } & \multirow[b]{2}{*}{$\begin{array}{l}\text { nZEB implementation and/energy plus/carbon neutral } \\
\text { buildings/district targets }\end{array}$} \\
\hline & & $\begin{array}{c}\text { New } \\
\text { buildings }\end{array}$ & $\begin{array}{l}\text { Existing } \\
\text { buildings }\end{array}$ & $\begin{array}{l}\text { Minimum } \\
\text { RE share }\end{array}$ & \\
\hline Amsterdam & $\checkmark$ & $\checkmark$ & & & $\begin{array}{l}\text { Only climate-neutral buildings will be built from } 2015 \text { [59]; } \\
\text { Edge building [247] }\end{array}$ \\
\hline Antwerp & $\checkmark$ & $\checkmark$ & $\checkmark$ & $\checkmark$ & Passive House district Nieuw Zuid will have 2,000 dwellings [145] \\
\hline Bangalore & & & & & N/A \\
\hline Batna & & & & & N/A \\
\hline Beijing & $\checkmark(*)$ & & & & China Academy of Building Research nearly net zero energy building [144] \\
\hline Berlin & $\checkmark$ & $\checkmark$ & & $\checkmark$ & Nullheizenergiehaus and EffizienzhausPlus mit Elektormobilität [248] \\
\hline Bilbao & $\sqrt{ }(*)$ & $\checkmark$ & & $\checkmark$ & N/A \\
\hline Braga & $\sqrt{ }(*)$ & $\checkmark$ & & & N/A \\
\hline Bregenz & $\checkmark$ & $\checkmark$ & $\checkmark$ & $\mathrm{P}$ & Vorkloster is the first shared residential area of passive house standard [249] \\
\hline Bydgoszcz & $\checkmark$ & $\checkmark$ & & & $\mathrm{N} / \mathrm{A}$ \\
\hline Copenhagen & $\checkmark$ & $\checkmark$ & $\checkmark$ & $\checkmark$ & $\begin{array}{l}\text { Nearly zero-energy building in Roskilde nearby Copenhagen } \\
\text { (Sems Have) [248] }\end{array}$ \\
\hline Florence & $\checkmark$ & $\checkmark$ & $\checkmark$ & $\checkmark$ & N/A \\
\hline Gothenburg & $\checkmark$ & & & & Hamnhuset in Sannegårdshamnen passively heated with $59 \mathrm{kWh} / \mathrm{m}^{2}$ [250] \\
\hline Grand Lyon & $\checkmark$ & $\checkmark$ & $\checkmark$ & $\checkmark$ & $\begin{array}{c}\text { HIKARI produces } 112 \text { and consumes } 97 \mathrm{kWh} / \mathrm{yr} / \mathrm{m}^{2} \text { [251]; } \\
\text { Pole SOLERE [252] }\end{array}$ \\
\hline Helsinki & $\checkmark$ & $\checkmark$ & & & Nearly zero-energy building in Järvenpää nearby Helsinki [248] \\
\hline Karlovac & $\checkmark$ & $\checkmark$ & & $\checkmark$ & N/A \\
\hline $\begin{array}{l}\text { London } \\
\text { Lviv }\end{array}$ & $\checkmark$ & $\checkmark$ & & $\checkmark$ & $\begin{array}{l}\text { Zero carbon Homes and Buildings initiative [96] and BedZED [253] } \\
\text { N/A }\end{array}$ \\
\hline Madrid & $\mathcal{J}(*)$ & $\checkmark$ & & $\checkmark$ & N/A (EspaiZero and LUCIA are premier examples in Spain $[254,255]$ ) \\
\hline Porto & $\sqrt{ }(*)$ & $\checkmark$ & & & N/A (SOLAR XXI in Lisbon is a premier example in Portugal [248]) \\
\hline Rio de Janeiro & & & & & $\begin{array}{l}\text { N/A } \\
\text { (The City Hall passed the Qualiverde legislation for green buildings [235]) }\end{array}$ \\
\hline Salé & & & & & N/A \\
\hline São Paulo & & & & & N/A (The Brazilian energy labelling system for buildings is RTQ [256]) \\
\hline Tianjin & $\sqrt{ }(*)$ & & & & $\begin{array}{l}\text { Tianjin Sino-Singapore Eco-City passive house with 90\% less energy } \\
\qquad[257,258]\end{array}$ \\
\hline Vila Nova de Gaia & $\checkmark(*)$ & $\checkmark$ & & & N/A (SOLAR XXI in Lisbon is a premier example in Portugal [248]) \\
\hline Vilnius & $\checkmark$ & $\checkmark$ & $\checkmark$ & $\checkmark$ & N/A (only a single-family house example) \\
\hline
\end{tabular}

Table A3. Sub-indicators for the density of the public transport system

\begin{tabular}{|c|c|c|c|c|c|c|c|c|c|c|}
\hline \multirow[b]{2}{*}{ City $\left(C_{j}\right)^{\mathrm{a}}$} & \multirow{2}{*}{$\begin{array}{c}\text { Bus/ } \\
\text { trolley bus } \\
\text { lines }\end{array}$} & \multirow{2}{*}{$\begin{array}{c}\text { Trams } \\
\text { Length } \\
{[\mathrm{km}]}\end{array}$} & \multirow{2}{*}{$\frac{\text { Subway/Metro }}{\text { Length }[\mathrm{km}]}$} & \multirow{2}{*}{$\begin{array}{c}\text { Total length } \\
\text { urban rail } \\
{[\mathrm{km}]^{\mathrm{b}}}\end{array}$} & \multirow{2}{*}{$\begin{array}{c}\text { Total urban } \\
\text { area }\left(\mathrm{km}^{2}\right) \\
{[259]}\end{array}$} & \multirow{2}{*}{$\begin{array}{c}\text { Urban rail } \\
\text { density } \\
{\left[\mathrm{km}^{2} \mathrm{~km}^{2}\right]}\end{array}$} & \multirow{2}{*}{$\begin{array}{l}\text { Daily } \\
\text { ridership per km } \\
\text { (metro) }\end{array}$} & \multicolumn{3}{|c|}{ Municipal bicycle sharing ${ }^{\mathrm{c}}$} \\
\hline & & & & & & & & Program & Stations & Bicycles \\
\hline Amsterdam & $\checkmark$ & 80.5 & 42.5 & 123 & 505 & 0.24 & 7,120 & $\checkmark$ & & \\
\hline Antwerp & $\checkmark$ & 116.6 & 7.6 & 124.2 & 635 & 0.20 & & $\checkmark$ & 144 & 1,800 \\
\hline Bangalore & $\checkmark$ & & 42.3 & 42.3 & 1,166 & 0.04 & 8,038 & $\mathrm{P}$ & & 150 \\
\hline Batna & $\checkmark$ & & & 0 & 85 & 0.00 & & & & \\
\hline Beijing & $\checkmark$ & Heritage & 572 & 572 & 4,144 & 0.14 & 11,800 & $\checkmark$ & 508 & 86,000 \\
\hline Berlin & $\checkmark$ & 190 & 151.7 & 341.7 & 1,347 & 0.25 & 9,390 & $\checkmark$ & $50+$ & 300 \\
\hline Bilbao & $\checkmark$ & 4.5 & 51 & 55.5 & 130 & 0.43 & 4,830 & & & \\
\hline Braga & $\checkmark$ & & & 0 & 183.4 & 0.00 & & & & \\
\hline Bregenz & $\checkmark$ & & & 0 & 29.51 & 0.00 & & $\checkmark$ & 14 & 70 \\
\hline Bydgoszcz & $\checkmark$ & 29.1 & & 29.1 & 175.98 & 0.17 & & & & \\
\hline Copenhagen & $\checkmark$ & & 21 & 21 & 88.25 & 0.24 & 7,050 & $\checkmark$ & 17 & 250 \\
\hline Florence & $\checkmark$ & 7.6 & & 7.6 & 220 & 0.03 & & $\checkmark$ & 65 & 975 \\
\hline Gothenburg & $\checkmark$ & 94 & & 94 & 215 & 0.44 & 3,033 & $\checkmark$ & 60 & 1,000 \\
\hline Grand Lyon & $\checkmark$ & 53.3 & 32.1 & 85.4 & 1,178 & 0.07 & 22,100 & $\checkmark$ & 346 & 3,200 \\
\hline Helsinki & $\checkmark$ & 96 & 21.1 & 117.1 & 641 & 0.18 & 8,090 & $\checkmark$ & & \\
\hline Karlovac & $\checkmark$ & & & 0 & N/A & 0.00 & & $\checkmark$ & & 17 \\
\hline London & $\checkmark$ & 28 & 402 & 430 & 1,738 & 0.25 & 11,940 & $\checkmark$ & 839 & 13,600 \\
\hline Lviv & $\checkmark$ & 73.5 & & 73.5 & 194 & 0.38 & & $\checkmark$ & & \\
\hline Madrid & $\checkmark$ & 27.8 & 293 & 320.8 & 1,321 & 0.24 & 5,940 & $\checkmark$ & 123 & 1,580 \\
\hline Porto & $\checkmark$ & Heritage & 112.4 & 112.4 & 777 & 0.14 & 1,407 & & & \\
\hline Rio de Janeiro & $\checkmark$ & 15 & 58 & 73 & 2,020 & 0.04 & 10,500 & $\checkmark$ & 60 & 300 \\
\hline Salé & $\checkmark$ & 19 & & 19 & 100 & 0.19 & & & & \\
\hline São Paulo & $\checkmark$ & & 78.4 & 78.4 & $3,043.00$ & 0.03 & 30,600 & $\checkmark$ & 241 & 600 \\
\hline Tianjin & $\checkmark$ & 7.86 & 162.8 & 170.66 & 2,771 & 0.06 & 1,080 & $\checkmark$ & & \\
\hline Vila Nova de Gaia & $\checkmark$ & & 9.2 & 9.2 & 168.46 & 0.05 & 1,407 & & & \\
\hline Vilnius & $\checkmark$ & & & 0 & 220 & 0.00 & & $\checkmark$ & 33 & 300 \\
\hline Sample average & $\checkmark$ & 56 & 129 & 112 & 924 & 0.15 & 9,020 & $\checkmark$ & 204 & 2,676 \\
\hline
\end{tabular}


Table A4. Evaluation of energy intensive industries in the cities ${ }^{\mathrm{a}, \mathrm{b}}$

\begin{tabular}{|c|c|c|c|c|c|c|c|c|c|c|c|c|c|c|c|c|c|c|c|c|c|c|c|c|c|}
\hline $\begin{array}{c}\text { Presence of energy } \\
\text { intensive } \\
\text { industries in the } \\
\text { cities }\end{array}$ & 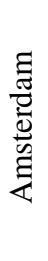 & 总 & 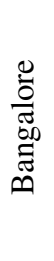 & $\underset{\Xi}{\tilde{\Xi}}$ & $\stackrel{\substack{\Xi \\
\oplus}}{\oplus}$ & $\stackrel{\Xi}{\overline{\bar{D}}}$ & $\begin{array}{l}\stackrel{0}{\pi} \\
: \vec{n}\end{array}$ & 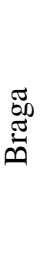 & 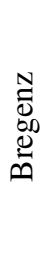 & 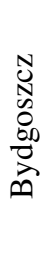 & 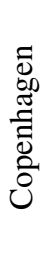 & $\begin{array}{l}8 \\
\stackrel{0}{0} \\
\frac{0}{I} \\
\frac{0}{I}\end{array}$ & 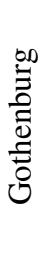 & 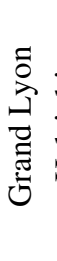 & $\begin{array}{l}\frac{\pi}{a} \\
\frac{0}{0} \\
\frac{0}{I}\end{array}$ & 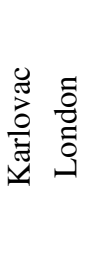 & $\stackrel{2}{3}$ & 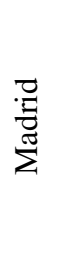 & & 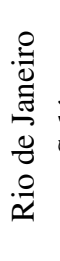 & $\frac{\mathscr{d}}{\pi}$ & 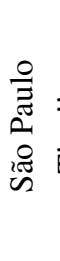 & : & 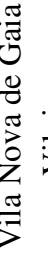 & $\stackrel{\substack{\Xi \\
\vdots}}{\vdots}$ \\
\hline $\begin{array}{l}\text { Basic chemicals and } \\
\text { chemical products }\end{array}$ & 2 & 2 & 1 & & 2 & 2 & 1 & 1 & & 1 & 2 & 1 & 2 & 2 & 1 & 1 & & 1 & & 2 & 1 & 1 & 2 & & 1 \\
\hline $\begin{array}{l}\text { Basic precious and } \\
\text { non-ferrous metals }\end{array}$ & & & 2 & 1 & 1 & 1 & & & & & & & 1 & 1 & 1 & 1 & 1 & 1 & & & & & 1 & & \\
\hline $\begin{array}{l}\text { Cement, lime and } \\
\text { plaster industry }\end{array}$ & & 1 & 1 & & 1 & & & & & 1 & & & & & & 1 & & 1 & & & 1 & & 1 & & \\
\hline $\begin{array}{c}\text { Ceramic products } \\
\text { industry }\end{array}$ & & 1 & & & 1 & 1 & & 1 & 1 & & & 1 & & & & 1 & 1 & & 1 & & & 1 & 1 & 1 & 1 \\
\hline $\begin{array}{l}\text { Iron and steel } \\
\text { industry }\end{array}$ & 1 & 1 & 1 & & & 1 & & & 1 & 1 & & & 1 & 1 & & & 1 & & 1 & & & & 1 & & \\
\hline $\begin{array}{c}\text { Pulp, paper and } \\
\text { paperboard industry }\end{array}$ & & & & 1 & 1 & 1 & & & & & 1 & 1 & & & 1 & 1 & & 1 & 1 & & & 2 & & 1 & \\
\hline $\begin{array}{l}\text { Refined petroleum } \\
\text { products industry }\end{array}$ & 2 & 2 & & & 2 & & 1 & & & & & & 1 & & 1 & 2 & & & 2 & 2 & 2 & & 2 & & \\
\hline
\end{tabular}

${ }^{\text {a }}$ The presence of at least one large enterprise/factory in the sector receives a binary value of 1

${ }^{\mathrm{b}}$ The presence of clustered industries in the sector receive a binary value of 2

Table A5. Sub-indicators for municipal waste management

\begin{tabular}{|c|c|c|c|}
\hline City $\left(C_{j}\right)$ & $\begin{array}{c}\text { Waste per capita [kg/capita] } \\
\text { [204-207] }\end{array}$ & $\begin{array}{l}\text { Reuse, recycling or } \\
\text { composting [\%] } \\
{[204-207]}\end{array}$ & $\begin{array}{l}\text { Total scoring waste } \\
\text { management }{ }^{\mathrm{a}}\end{array}$ \\
\hline Amsterdam & 406 & 40.0 & 2.6 \\
\hline Antwerp & 433 & 63.3 & 3.4 \\
\hline Bangalore & 269 & 20.0 & 2.1 \\
\hline Batna & 255 & 4.5 & 1.6 \\
\hline Beijing & 310 & 3.0 & 1.4 \\
\hline Berlin & 395 & 67.7 & 3.6 \\
\hline Bilbao & 480 & 33.3 & 2.1 \\
\hline Braga & 401 & 30.4 & 2.2 \\
\hline Bregenz & 409 & 66.7 & 3.5 \\
\hline Bydgoszcz & 294 & 31.5 & 2.5 \\
\hline Copenhagen & 380 & 46.3 & 2.8 \\
\hline Florence & 625 & 49.0 & 2.4 \\
\hline Gothenburg & 423 & 48.0 & 2.8 \\
\hline Grand Lyon & 531 & 44.0 & 2.4 \\
\hline Helsinki & 284 & 40.6 & 2.9 \\
\hline Karlovac & 358 & 18.4 & 1.9 \\
\hline London & 435 & 23.7 & 1.9 \\
\hline Lviv & 300 & 4.0 & 1.5 \\
\hline Madrid & 385 & 33.3 & 2.4 \\
\hline Porto & 401 & 30.4 & 2.2 \\
\hline Rio de Janeiro & 507 & 3.0 & 1.0 \\
\hline Salé & 241 & 10.0 & 1.8 \\
\hline São Paulo & 513 & 1.0 & 0.9 \\
\hline Tianjin & 371 & 3.0 & 1.3 \\
\hline Vila Nova de Gaia & 401 & 30.4 & 2.2 \\
\hline Vilnius & 539 & 27.8 & 1.8 \\
\hline Sample average & 398 & 29.7 & 2.2 \\
\hline
\end{tabular}

${ }^{\text {a }}$ Sum of ratios over the average values of $433 \mathrm{~kg}$ per capita minus the top score and $26.8 \%$ for the integrated sample 
Table A6. Sub-indicators for municipal wastewater treatment

\begin{tabular}{|c|c|c|c|c|c|c|c|}
\hline \multirow{2}{*}{ City $\left(C_{j}\right)$} & \multirow{2}{*}{$\begin{array}{c}\text { Discharge } \\
\text { without } \\
\text { treatment [\%] } \\
{[208-210]} \\
\end{array}$} & \multicolumn{3}{|c|}{$\begin{array}{l}\text { Percentage of compliance [\%] } \\
{[208-210]}\end{array}$} & \multirow{2}{*}{$\begin{array}{l}\text { Scoring } \\
\text { coverage }^{\mathrm{b}}\end{array}$} & \multirow{2}{*}{$\begin{array}{l}\text { Scoring } \\
\text { compliance }^{\mathrm{c}}\end{array}$} & \multirow{2}{*}{ Total } \\
\hline & & BOD & COD & TSS & & & \\
\hline Amsterdam & 0 & 100 & 100 & 100 & 2.0 & 1.0 & 3.0 \\
\hline Antwerp & 0 & 100 & 100 & 100 & 2.0 & 1.0 & 3.0 \\
\hline Bangalore & 60 & 0 & 0 & 0 & 0.2 & 0.0 & 0.2 \\
\hline Batna & 54 & 0 & 0 & 0 & 0.4 & 0.0 & 0.4 \\
\hline Beijing & 3 & 100 & 100 & 100 & 1.9 & 1.0 & 2.9 \\
\hline Berlin & 0 & 100 & 100 & 100 & 2.0 & 1.0 & 3.0 \\
\hline Bilbao & 0 & 100 & 100 & 100 & 2.0 & 1.0 & 3.0 \\
\hline Braga & 0 & 100 & 100 & 100 & 2.0 & 1.0 & 3.0 \\
\hline Bregenz & 0 & 100 & 100 & 100 & 2.0 & 1.0 & 3.0 \\
\hline Bydgoszcz & 0 & 100 & 100 & 100 & 2.0 & 1.0 & 3.0 \\
\hline Copenhagen & 0 & 100 & 100 & 100 & 2.0 & 1.0 & 3.0 \\
\hline Florence & 0 & 100 & 100 & 100 & 2.0 & 1.0 & 3.0 \\
\hline Gothenburg & 0 & 100 & 100 & 100 & 2.0 & 1.0 & 3.0 \\
\hline Grand Lyon & 0 & 100 & 100 & 100 & 2.0 & 1.0 & 3.0 \\
\hline Helsinki & 0 & 100 & 100 & 100 & 2.0 & 1.0 & 3.0 \\
\hline Karlovac & 0 & 100 & 100 & 100 & 2.0 & 1.0 & 3.0 \\
\hline London & 0 & 100 & 100 & 100 & 2.0 & 1.0 & 3.0 \\
\hline Lviv & 18 & 50 & 50 & 50 & 1.5 & 0.5 & 2.0 \\
\hline Madrid & 0 & 100 & 100 & 100 & 2.0 & 1.0 & 3.0 \\
\hline Porto & 0 & 100 & 100 & 100 & 2.0 & 1.0 & 3.0 \\
\hline Rio de Janeiro & 35 & 75 & 75 & 75 & 1.0 & 0.8 & 1.8 \\
\hline Salé & 64 & 0 & 0 & 0 & 0.1 & 0.0 & 0.1 \\
\hline São Paulo & 29 & 75 & 75 & 75 & 1.1 & 0.8 & 1.9 \\
\hline Tianjin & 9 & 100 & 100 & 100 & 1.7 & 1.0 & 2.7 \\
\hline Vila Nova de Gaia & 0 & 0 & 0 & - & 2.0 & 0.0 & 2.0 \\
\hline Vilnius & 0 & 100 & 100 & 100 & 2.0 & 1.0 & 3.0 \\
\hline Sample average & 10 & 84 & 84 & 84 & 1.7 & 0.8 & 2.5 \\
\hline
\end{tabular}

Table A7. Sub-indicators for compact urban form and green areas

\begin{tabular}{|c|c|c|c|c|c|c|c|c|c|c|c|c|c|c|c|c|c|c|c|c|c|c|c|c|c|c|}
\hline $\begin{array}{l}\text { Urban form } \\
\text { and municipal } \\
\text { management }\end{array}$ & 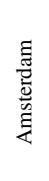 & 总 & 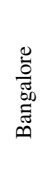 & 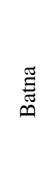 & 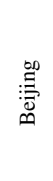 & 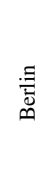 & $\begin{array}{l}\stackrel{8}{\mathscr{I}} \\
\stackrel{\overline{0}}{\bar{m}}\end{array}$ & 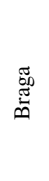 & 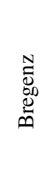 & 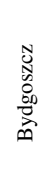 & 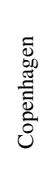 & $\begin{array}{l}\mathbb{U} \\
\stackrel{0}{0} \\
\stackrel{0}{I}\end{array}$ & 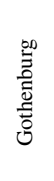 & 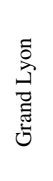 & 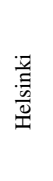 & 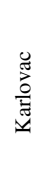 & 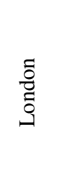 & $\stackrel{3}{3}$ & $\begin{array}{l}\vec{E} \\
\bar{E} \\
\Sigma\end{array}$ & ڤ̊ํㅁ & 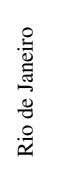 & $\frac{\omega}{\tilde{J}}$ & 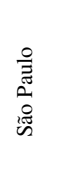 & : 灵 & 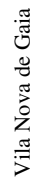 & 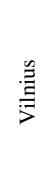 \\
\hline Compact urban form $(1-3)^{\mathrm{a}}$ & 2 & 2 & 1 & 2 & 1 & 2 & 2 & 2 & 2 & 2 & 2 & 1 & 2 & 2 & 2 & 2 & 3 & 2 & 1 & 2 & 1 & 1 & 1 & 1 & 2 & 2 \\
\hline $\begin{array}{r}\text { Polycentricity (core areas) } \\
{[196]}\end{array}$ & $\begin{array}{l}\checkmark \\
(4)\end{array}$ & & & & & & $\begin{array}{l}\checkmark \\
(2)\end{array}$ & & & & & & & $\begin{array}{l}\checkmark \\
(3)\end{array}$ & & & $\begin{array}{l}\checkmark \\
(6)\end{array}$ & & $\begin{array}{l}\checkmark \\
(2)\end{array}$ & & & & & & & \\
\hline $\begin{array}{r}\text { Population core areas [\%] } \\
{[196]}\end{array}$ & 69.8 & 47.0 & & & & 78.8 & 52.6 & & & & 61.4 & 49.0 & 56.2 & 67.9 & 69.5 & & 80.2 & & 74.4 & 81.4 & & & & & & \\
\hline Sprawl index [\%] [196] & 3.4 & -2.8 & $>0$ & $>0$ & $>0$ & 0.8 & 2.8 & $>0$ & $>0$ & $>0$ & 1.8 & 3.5 & -2.0 & -2.1 & -1.5 & $>0$ & -6.8 & $>0$ & 4.6 & 4.3 & $>0$ & $>0$ & $>0$ & $>0$ & $>0$ & $>0$ \\
\hline Urban green space (1-3) & 2 & 1 & 1 & 1 & 1 & 2 & 2 & 2 & 2 & 2 & 2 & 2 & 3 & 2 & 2 & 2 & 2 & 2 & 2 & 2 & 2 & 1 & 2 & 1 & 2 & 2 \\
\hline Urban park intensity & $\checkmark$ & $\checkmark$ & $\checkmark$ & $\sqrt{ }$ & $\sqrt{ }$ & $\checkmark$ & $\checkmark$ & $\checkmark$ & $\checkmark$ & $\checkmark$ & $\checkmark$ & $\checkmark$ & $\checkmark$ & $\checkmark$ & $\checkmark$ & $\checkmark$ & $\sqrt{ }$ & $\checkmark$ & $\checkmark$ & $\checkmark$ & $\checkmark$ & $\sqrt{ }$ & $\checkmark$ & $\checkmark$ & $\checkmark$ & $\checkmark$ \\
\hline $\begin{array}{r}\text { Percentage green areas [\%] } \\
{[211]}\end{array}$ & 20.3 & 13.8 & & & & 24.2 & & & & & 19.2 & & 53.7 & 22.0 & & & 33.0 & & 35.0 & & 29.0 & & 6.6 & & & 29.9 \\
\hline $\begin{array}{r}\text { Impermeable surfaces [\%] } \\
{[200]}\end{array}$ & 44.5 & 63.6 & & & & & & & & & & & 28.9 & 54.4 & & & & & & & & & & & & 46.2 \\
\hline $\begin{array}{r}\text { Green area per capita }\left[\mathrm{m}^{2}\right] \\
{[196]}\end{array}$ & 207 & 306 & & & & 206 & 208 & & & & 376 & 500 & 292 & 472 & 77 & & 35.2 & & 24.2 & 66.3 & 58.0 & & 54.7 & & & \\
\hline Green corridor quality (1-3) & 3 & 1 & 1 & 1 & 2 & 3 & 2 & 2 & 1 & 2 & 2 & 2 & 2 & 2 & 2 & 3 & 3 & 1 & 3 & 2 & 3 & 1 & 3 & 1 & 2 & 2 \\
\hline Natural reserves [212] & 3 & 2 & 0 & 0 & 6 & 5 & 2 & 3 & 2 & 5 & 4 & 5 & 4 & 3 & 2 & 5 & 3 & 7 & 6 & 3 & 4 & 1 & 4 & 1 & 3 & 5 \\
\hline RAMSAR [213] & 3 & 3 & 0 & 6 & 0 & 2 & 5 & 1 & 1 & 0 & 2 & 0 & 4 & 1 & 3 & 1 & 6 & 0 & 3 & 1 & 0 & 2 & 0 & 0 & 1 & 2 \\
\hline National park [212] & 4 & 0 & 1 & 1 & 2 & 1 & 0 & 1 & 0 & 1 & 1 & 1 & 0 & 0 & 4 & 1 & 1 & 1 & 1 & 1 & 2 & 0 & 0 & 0 & 1 & 0 \\
\hline Total number evaluation & 10 & 5 & 1 & 7 & 8 & 8 & 7 & 5 & 3 & 6 & 7 & 6 & 8 & 4 & 9 & 7 & 10 & 8 & 10 & 5 & 6 & 3 & 4 & 1 & 5 & 7 \\
\hline Total area $>2,700 \mathrm{~km}^{2}$ & $\checkmark$ & & & & & $\checkmark$ & & & & & & & & & & $\checkmark$ & $\checkmark$ & & $\checkmark$ & & & & $\checkmark$ & & & \\
\hline Average category score & 2.3 & 1.3 & 1.0 & 1.3 & 1.3 & 2.3 & 2.0 & 2.0 & 1.7 & 2.0 & 2.0 & 1.7 & 2.3 & 2.0 & 2.0 & 2.3 & 2.7 & 1.7 & 2.0 & 2.0 & 2.0 & 1.0 & 2.0 & 1.0 & 2.0 & 2.0 \\
\hline
\end{tabular}


Table A8. Sub-indicators for benchmarking R\&D and innovation policy orientation (Part I)

\begin{tabular}{|c|c|c|c|c|c|c|c|c|c|c|}
\hline $\mathrm{R} \& \mathrm{D}$ and innovation policy orientation ${ }^{\mathrm{a}}$ & AT & $\mathrm{BE}$ & $\mathrm{BR}$ & $\mathrm{CN}$ & $\mathrm{DE}$ & DK & $\mathrm{DZ}$ & ES & FI & FR \\
\hline $\mathrm{R} \& \mathrm{D}$ funding approach score & 3 & 1 & 3 & 3 & 3 & 3 & 1 & 1 & 3 & 2 \\
\hline General (no thematic focus) & $\checkmark$ & $\checkmark$ & $\checkmark$ & $\checkmark$ & $\checkmark$ & $\checkmark$ & $\checkmark$ & $\checkmark$ & $\checkmark$ & $\checkmark$ \\
\hline Thematic focus (calls) & $\checkmark$ & & $\checkmark$ & $\checkmark$ & $\checkmark$ & $\checkmark$ & & & $\checkmark$ & \\
\hline Energy environment/smart cities priority & $\checkmark$ & & $\checkmark$ & $\checkmark$ & $\checkmark$ & $\checkmark$ & & & $\checkmark$ & $\checkmark$ \\
\hline $\mathrm{R} \& \mathrm{D}$ expenditure score & 3 & 2 & 2 & 2 & 3 & 3 & 1 & 2 & 3 & 2 \\
\hline GERD/GDP (Percentage) & 3.01 & 2.46 & 1.17 & 2.07 & 2.88 & 3.01 & 0.07 & 1.22 & 2.91 & 2.23 \\
\hline Smart city demonstration site $[222]^{\mathrm{b}}$ & & & & & & $\checkmark$ & & $\checkmark$ & $\checkmark$ & $\checkmark$ \\
\hline Average category score & 3 & 1.5 & 2.5 & 2.5 & 3.0 & 3 & 1.0 & 1.5 & 3 & 2 \\
\hline
\end{tabular}

${ }^{a}$ The policy scan involves R\&D funding institutions, support mechanisms, JRC RIO country reports [227], OECD/UNESCO [228] statistics, and other reports, e.g. [265]

b Amsterdam, Bilbao, Copenhagen. Florence, Gothenburg, Lyon, Helsinki, and London are demonstration sites based on SCIS [222], excludes other cities in the country

Table A8. Sub-indicators for benchmarking R\&D and innovation policy orientation (Part II)

\begin{tabular}{|c|c|c|c|c|c|c|c|c|c|c|c|}
\hline $\mathrm{R} \& \mathrm{D}$ and innovation policy orientation ${ }^{\mathrm{a}}$ & HR & IN & IT & LT & MA & NL & PL & PT & SE & UA & UK \\
\hline $\mathrm{R} \& \mathrm{D}$ funding approach score & 3 & 3 & 2 & 2 & 2 & 3 & 2 & 2 & 2 & 2 & 2 \\
\hline General (no thematic focus) & $\checkmark$ & $\checkmark$ & $\checkmark$ & $\checkmark$ & $\checkmark$ & $\checkmark$ & $\checkmark$ & $\checkmark$ & $\checkmark$ & $\checkmark$ & $\checkmark$ \\
\hline Thematic focus (calls) & $\checkmark$ & $\checkmark$ & & & & $\checkmark$ & & & & & \\
\hline Energy environment / smart cities priority & $\checkmark$ & $\checkmark$ & $\checkmark$ & $\checkmark$ & $\checkmark$ & $\checkmark$ & $\checkmark$ & $\checkmark$ & $\checkmark$ & $\checkmark$ & $\checkmark$ \\
\hline R\&D expenditure score & 2 & 1 & 2 & 2 & 1 & 2 & 2 & 2 & 3 & 1 & 2 \\
\hline GERD/GDP (Percentage) & 0.85 & 0.69 & 1.34 & 1.04 & 0.71 & 2.01 & 1.00 & 1.28 & 3.27 & 0.62 & 1.70 \\
\hline Smart city demonstration site $[222]^{\mathrm{b}}$ & & & $\checkmark$ & & & $\checkmark$ & & & $\checkmark$ & & $\checkmark$ \\
\hline Average category score & 2.5 & 2.0 & 2.0 & 2 & 1.5 & 2.5 & 2.0 & 2 & 2.5 & 1.5 & 2.0 \\
\hline
\end{tabular}

Amsterdam, Bilbao, Copenhagen, Florence, Gothenburg, Lyon, Helsinki, and London are demonstration sites based on SCIS [222], excludes other cities in the country

Table A9. Sub-indicators for benchmarking national patents in clean technologies (Part I)

\begin{tabular}{|c|c|c|c|c|c|c|c|c|c|c|}
\hline National patents in clean technologies & AT & $\mathrm{BE}$ & $\mathrm{BR}$ & $\mathrm{CN}$ & $\mathrm{DE}$ & DK & $\mathrm{DZ}$ & ES & FI & FR \\
\hline Total Y02 or Y04 patents ${ }^{\mathrm{a}}$ & 20,145 & 9,285 & 16,924 & 43,030 & 146,946 & 7,508 & 38 & 21,699 & 3,145 & 57,554 \\
\hline Building technologies (Y02B) & 4,104 & 1,015 & 2,123 & 10,000 & 21,158 & 1,249 & 6 & 3,139 & 719 & 6,162 \\
\hline Energy generation(Y02E) & 9,428 & 5,743 & 8,654 & 10,000 & 60,958 & 4,762 & 23 & 12,535 & 1,652 & 25,948 \\
\hline Transportation (Y02T) & 5,743 & 2,260 & 5,234 & 10,000 & 60,961 & 1,140 & 2 & 5,179 & 659 & 23,893 \\
\hline Capture and storage (Y02C) & 402 & 142 & 525 & 3,030 & 1,448 & 211 & 5 & 469 & 52 & 769 \\
\hline Smart grid (Y04S) & 468 & 125 & 388 & 10,000 & 2,421 & 146 & 2 & 377 & 63 & 782 \\
\hline Y02 or Y04 patent score (1-3) & 2 & 2 & 2 & 3 & 3 & 2 & 1 & 2 & 2 & 3 \\
\hline Percentage of total patents [\%] & 2.17 & 2.02 & 3.25 & 4.81 & 2.6 & 2.17 & 2.61 & 2.29 & 2.12 & 2.34 \\
\hline Total percentage score (1-3) & 2 & 2 & 3 & 3 & 3 & 2 & 2 & 2 & 2 & 2 \\
\hline Average category score & 2.0 & 2.0 & 2.5 & 3.0 & 3.0 & 2.0 & 1.5 & 2.0 & 2.0 & 2.5 \\
\hline
\end{tabular}

Table A9. Sub-indicators for benchmarking national patents in clean technologies (Part II)

\begin{tabular}{|c|c|c|c|c|c|c|c|c|c|c|c|}
\hline National patents in clean technologies & HR & IN & IT & LT & MA & NL & PL & PT & SE & UA & UK \\
\hline Total Y02 or Y04 patents ${ }^{\mathrm{a}}$ & 482 & 3,183 & 10,712 & 129 & 847 & 10,222 & 3,313 & 2,607 & 8,813 & 2,168 & 27,627 \\
\hline Building technologies (Y02B) & 81 & 431 & 1,595 & 14 & 90 & 1,599 & 411 & 406 & 917 & 130 & 6,340 \\
\hline Energy generation $(\mathrm{Y} 02 \mathrm{E})$ & 331 & 1,784 & 4,896 & 103 & 661 & 5,866 & 2,048 & 1,674 & 5,192 & 1,792 & 10,000 \\
\hline Transportation (Y02T) & 42 & 753 & 3,926 & 8 & 55 & 2,365 & 686 & 395 & 2,572 & 200 & 10,000 \\
\hline Capture and storage (Y02C) & 14 & 133 & 146 & 0 & 29 & 256 & 113 & 76 & 48 & 41 & 578 \\
\hline Smart grid (Y04S) & 14 & 82 & 149 & 4 & 12 & 136 & 55 & 56 & 84 & 5 & 709 \\
\hline Y02 or Y04 patent score (1-3) & 1 & 2 & 2 & 1 & 1 & 2 & 2 & 2 & 2 & 1 & 2 \\
\hline Percentage of total patents [\%] & 2.82 & 6.77 & 2.23 & 2.97 & 7.45 & 3.54 & 1.68 & 2.12 & 2.22 & 1.98 & 3.78 \\
\hline Total percentage score (1-3) & 2 & 3 & 2 & 2 & 3 & 3 & 1 & 2 & 2 & 2 & 3 \\
\hline Average category score & 1.5 & 2.5 & 2.0 & 1.5 & 2.0 & 2.5 & 1.5 & 2.0 & 2.0 & 1.5 & 2.5 \\
\hline
\end{tabular}

Table A10. Number of public, private, and SCImago ranked universities

\begin{tabular}{|c|c|c|c|c|c|c|c|c|c|c|c|c|c|c|c|c|c|c|c|c|c|c|c|c|c|c|}
\hline $\begin{array}{l}\text { Universities and research institutes } \\
\text { in the local innovation system }\end{array}$ & 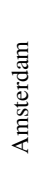 & 范 & 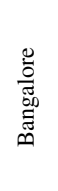 & 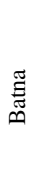 & 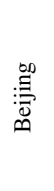 & $\stackrel{\Xi}{\Xi}$ & 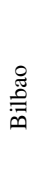 & 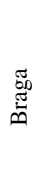 & 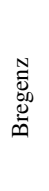 & 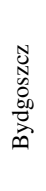 & 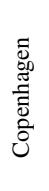 & 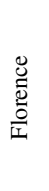 & 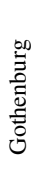 & 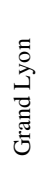 & $\frac{\vec{a}}{D}$ & 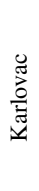 & 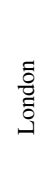 & 永 & 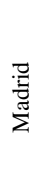 & 产 & 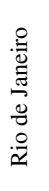 & 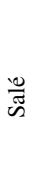 & 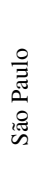 & : & 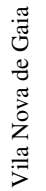 & 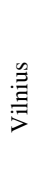 \\
\hline Number of universities/institutes & 3 & 4 & 6 & 2 & $36+$ & 7 & 2 & 2 & 1 & 2 & 3 & 2 & 1 & 6 & 3 & 1 & 19 & 4 & 8 & 7 & 10 & 2 & 7 & 18 & 7 & 2 \\
\hline Public/polytechnic & 3 & 3 & 6 & 2 & $33+$ & 4 & 1 & 1 & 1 & 2 & 3 & 2 & 1 & 5 & 2 & 1 & 18 & 3 & 5 & 2 & 7 & 1 & 4 & 18 & 2 & 2 \\
\hline Private universities/colleges & 0 & 1 & 0 & 0 & 3 & 3 & 1 & 1 & 0 & 0 & 0 & 0 & 0 & 1 & 1 & 0 & 1 & 1 & 3 & 5 & 3 & 1 & 3 & 0 & 5 & 0 \\
\hline SCImago ranked ${ }^{\mathrm{a}}$ & $\checkmark$ & $\checkmark$ & $\checkmark$ & $\checkmark$ & $\checkmark$ & $\checkmark$ & $\checkmark$ & $\checkmark$ & & $\checkmark$ & $\checkmark$ & $\checkmark$ & $\checkmark$ & $\checkmark$ & $\checkmark$ & & $\checkmark$ & $\checkmark$ & $\checkmark$ & $\checkmark$ & $\checkmark$ & $\checkmark$ & $\checkmark$ & $\checkmark$ & $\checkmark$ & $\checkmark$ \\
\hline Located in the city & 2 & 2 & 6 & 1 & 33 & 4 & 1 & 1 & 0 & 1 & 3 & 1 & 1 & 5 & 3 & 0 & 20 & 2 & 5 & 2 & 5 & 1 & 5 & 12 & 2 & 2 \\
\hline Located in the country & 16 & 11 & 170 & 19 & 413 & 78 & 60 & 25 & 19 & 55 & 8 & 65 & 23 & 118 & 13 & 4 & 112 & 11 & 60 & 25 & 94 & 12 & 94 & 413 & 25 & 7 \\
\hline Concentration in city [\%] & 13 & 18 & 4 & 5 & 8 & 5 & 2 & 4 & 0 & 2 & 38 & 2 & 4 & 4 & 23 & 0 & 18 & 18 & 8 & 8 & 5 & 8 & 5 & 3 & 8 & 29 \\
\hline University weighted score & 5 & 6 & 12 & 3 & $36+$ & 11 & 3 & 3 & 1 & 3 & 6 & 3 & 2 & 11 & 6 & 1 & 39 & 6 & 13 & 9 & 15 & 3 & 12 & 30 & 9 & 4 \\
\hline
\end{tabular}

